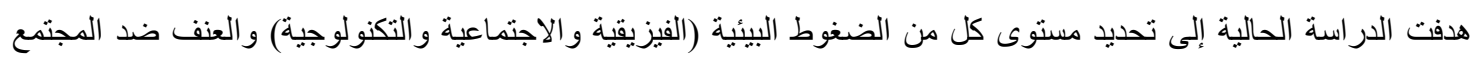

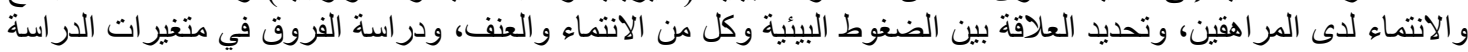

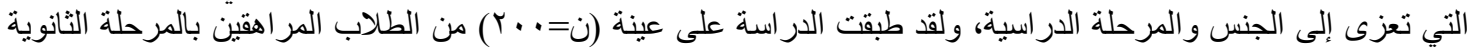

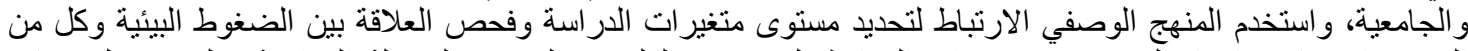

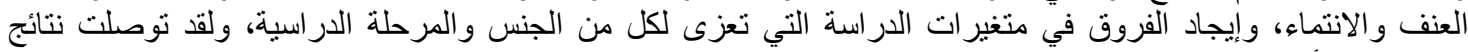

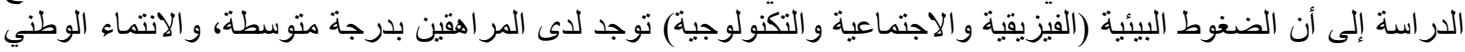

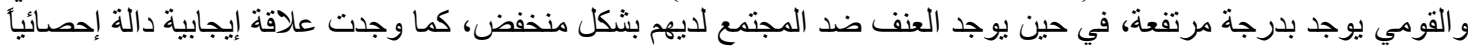

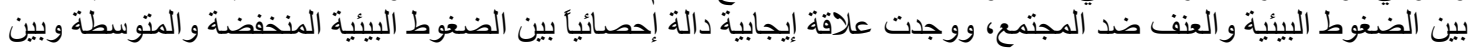

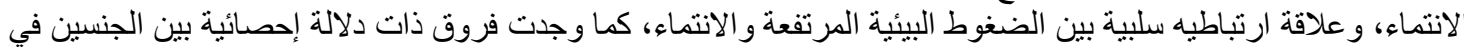

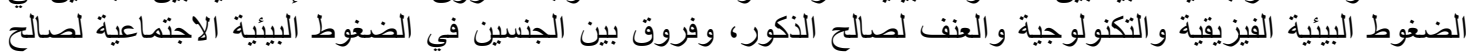

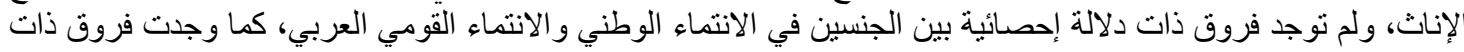

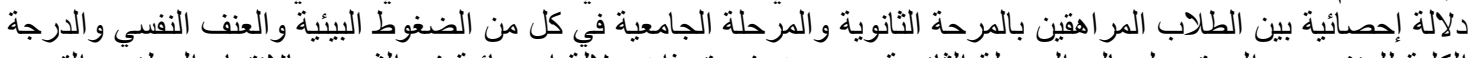

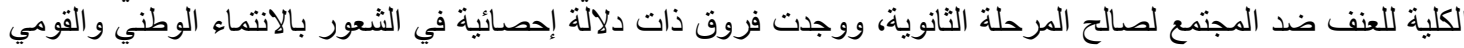

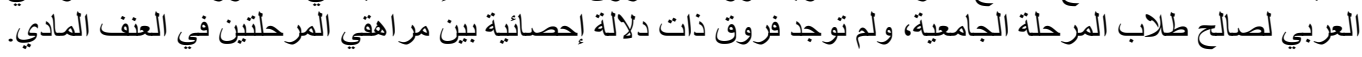

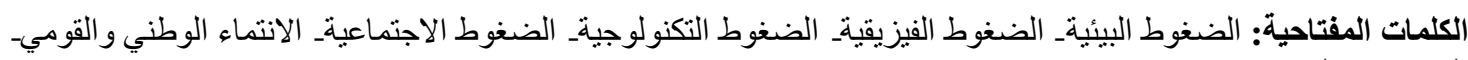

العنف ضد المجتمع. المغنة.

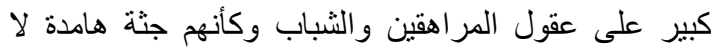

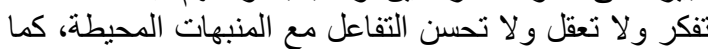

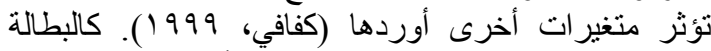

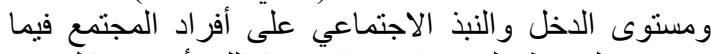

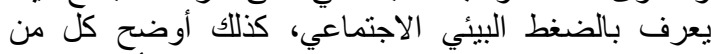

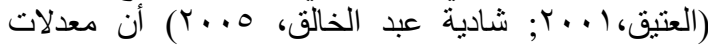

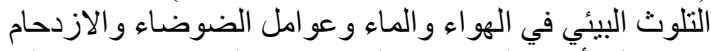

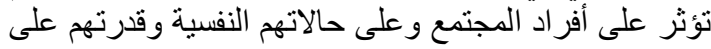

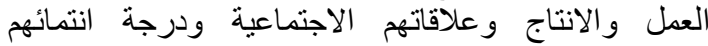

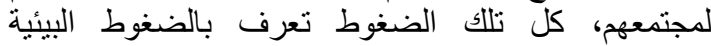

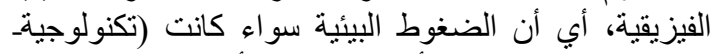

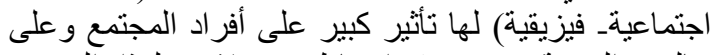

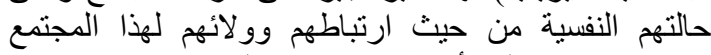

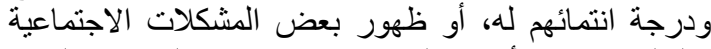
و والسلوكية بين أفراد المجتمع كممارسة سلوكيات العنف العنف و والعدوان ضد المجتمع و أفر اده.

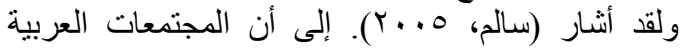

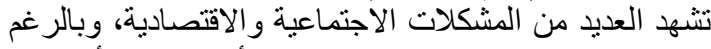

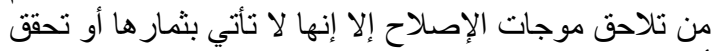
أهدافها كما ينبغي، وقد يرجع سبب ذللك إلى ضعف الثار الثعور
إن الضغوط بمختلف أشكالها تعد صخرة، لغير المستعد لها لها

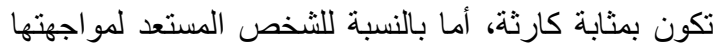

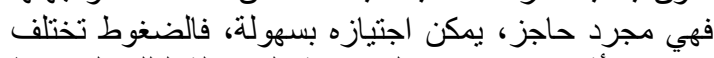

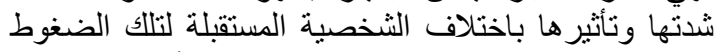

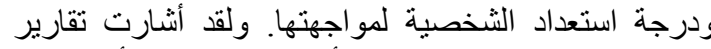

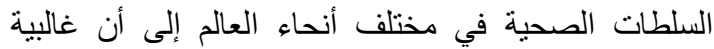

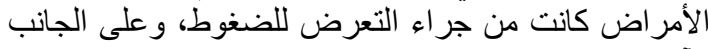

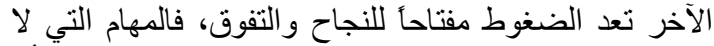
يحدد لها فترة زمنية محددة لإنجاز ها قد لا لا تتجز ابداً وأن ألان

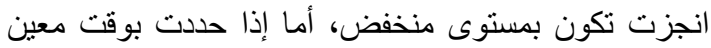

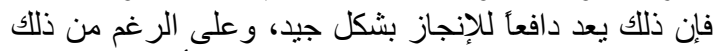

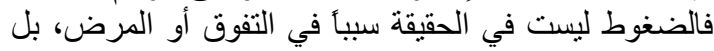
السبب الحقيقي هو الانسان الذي ينعامل مع هذه الضغوط. الضئ. (صالح، (1991).

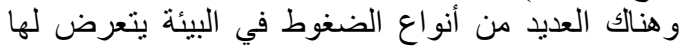

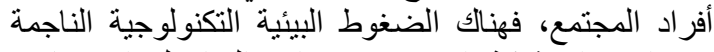

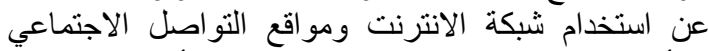

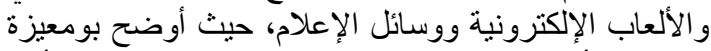

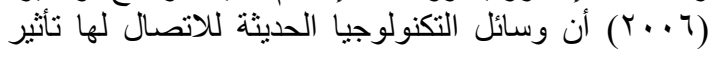

* Corresponding author:

Dr. Sally salah anter kassem 31

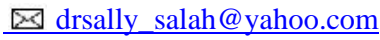




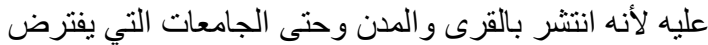

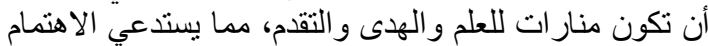

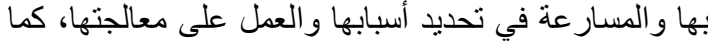

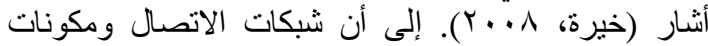

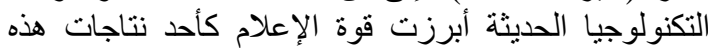
التكنولوجيا، حيث نقلت تجارب الثئ الثعوب الإب الإيجابية والسلبية

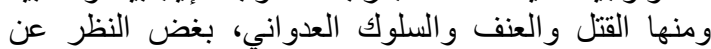

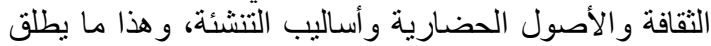
عليه اسم العولمة الثقافية، و التي قد تصل التئل إلى العولمة القيمية

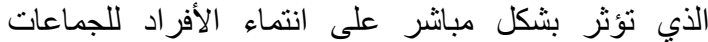

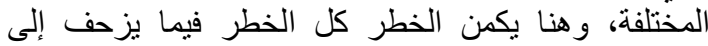

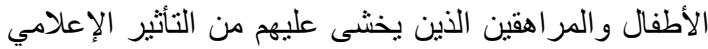

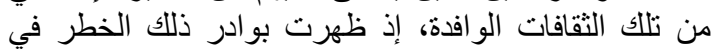

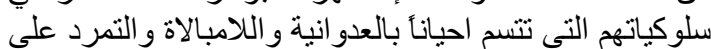

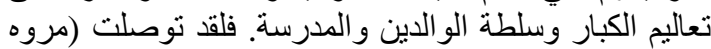

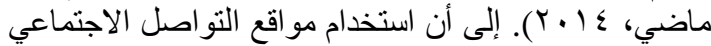

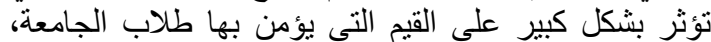

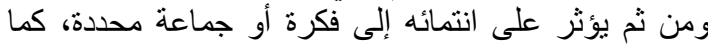

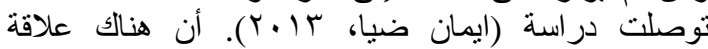

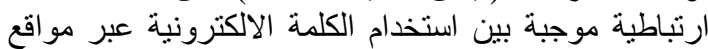

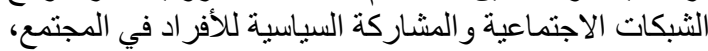

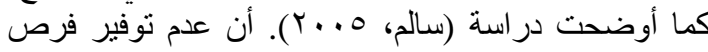

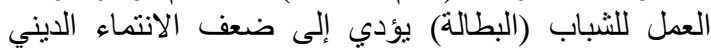

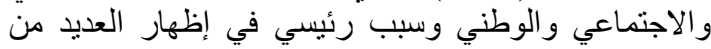

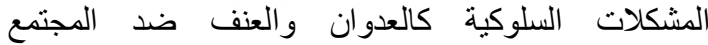

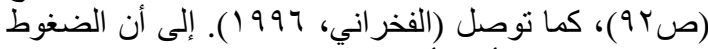

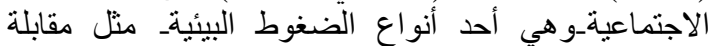

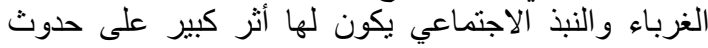

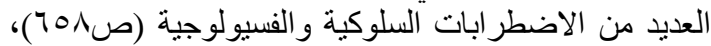

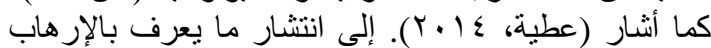
الإلكتروني (كأحد الضغوط البيئية التكنولوجية التية) وهو استخدام

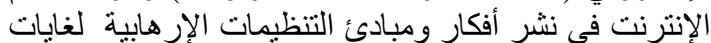

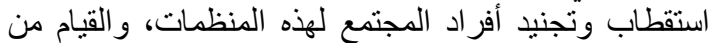

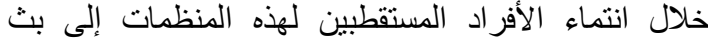

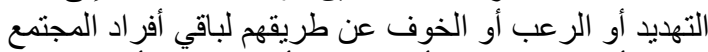

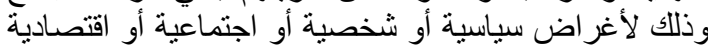

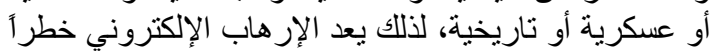

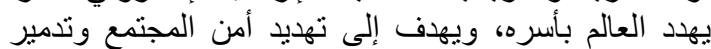

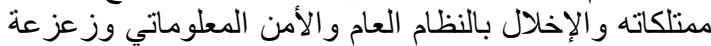

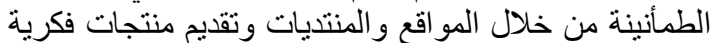

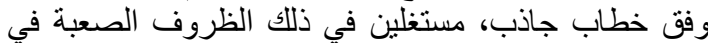
كثير من مجتمعات العالم العربي و والاسلامي.

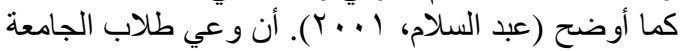

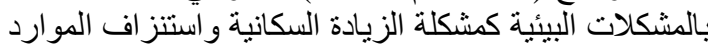

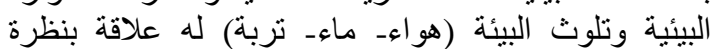

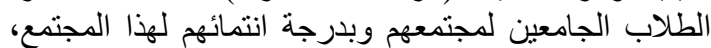

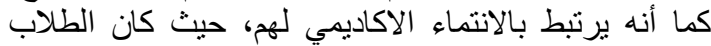

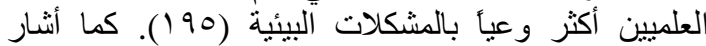

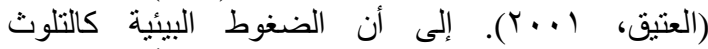

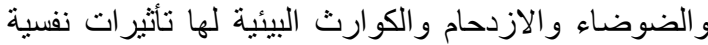

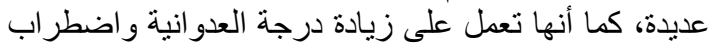

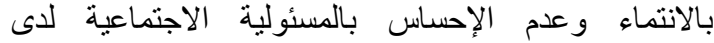

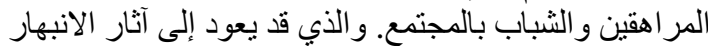

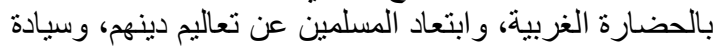

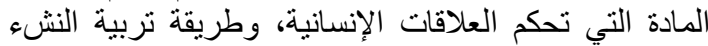

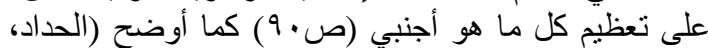

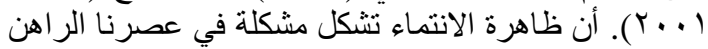

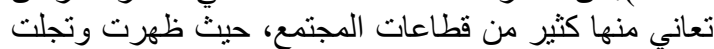

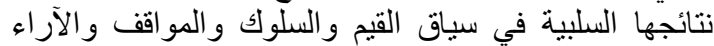

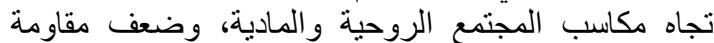
التيار ات الفكرية التي تتصار ع على خلى خريطة العالم في إظهار

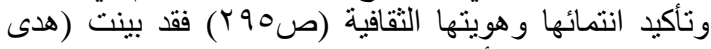

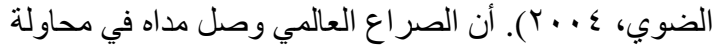

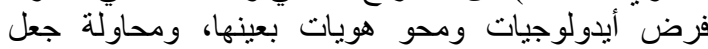

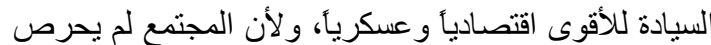

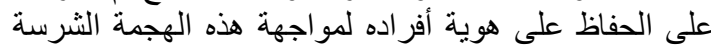

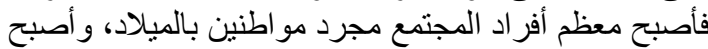
الجيل فاقد للهوية ليس لديه اعتزاز قومي وسلالي ليشعر

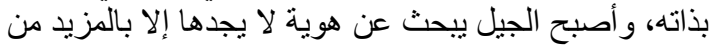

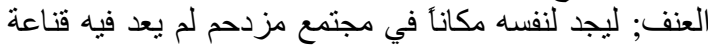

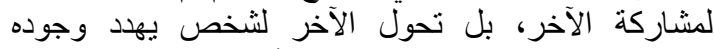

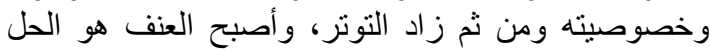

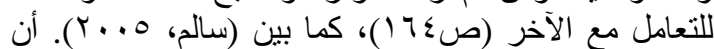

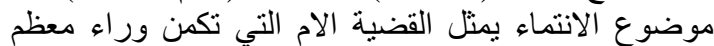

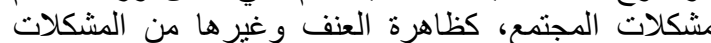

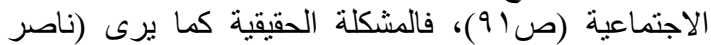

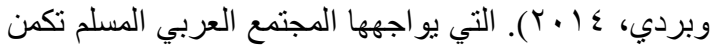

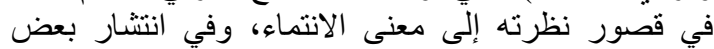

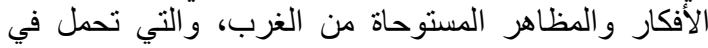

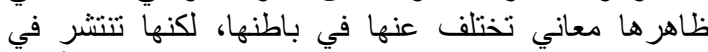

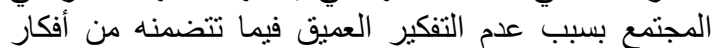

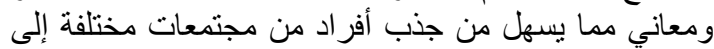

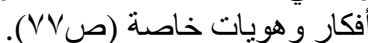

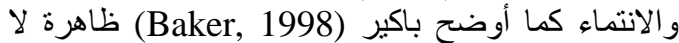

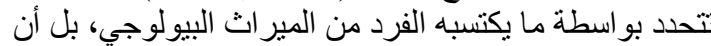

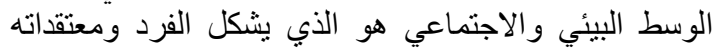

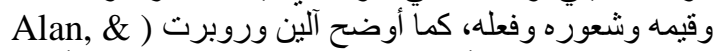
(Robert, 1998

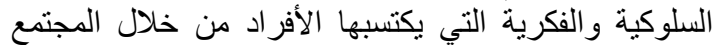

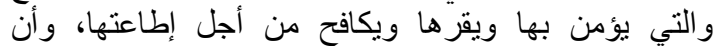

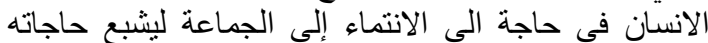

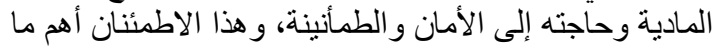

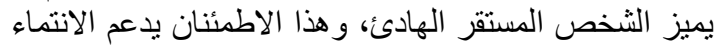

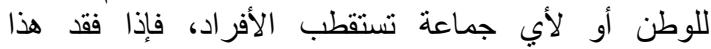

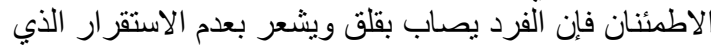

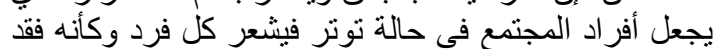

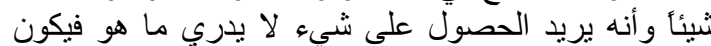

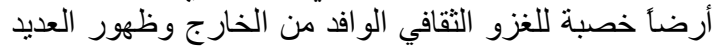

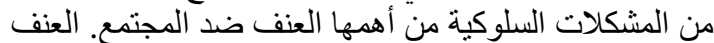

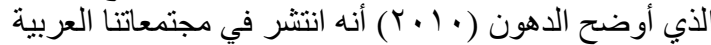

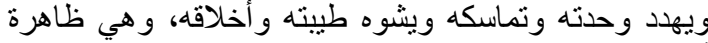

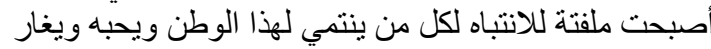


يمكن التحكم فيها والسيطرة عليها بسهولة واستقطابها وتجنيدها لتنفيذ مخططات خاصة.

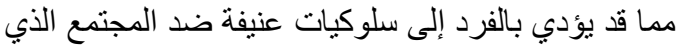

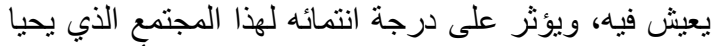

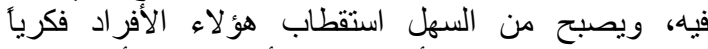

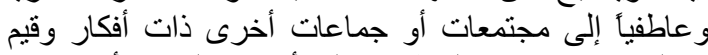

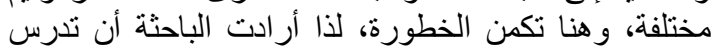

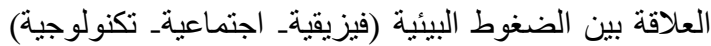

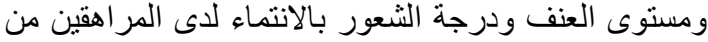
طلاب التعليم الثانوي و الجامعي. وكان التساؤل الرئيسي للبحث هو هل هل هنالك علاقة بين درجة شعور المراهقين بالضغوط التئين البيئية المختلفة (فيزيقية.

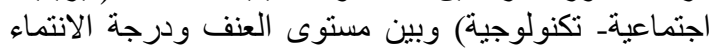

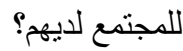
وتفرع من هذا السؤ ال الرئيسي مجموعة من التساؤلات كما أ-ـي. ما مستوى كل من الضغوط البيئية المختلفة (الفيزيقية.

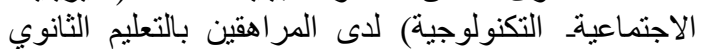
و الجامعي ؟ بأبن با - ما مستوى العنف ضد المجتمع لدى المر اهقين بالتعليم

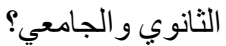
rــ ما مستوى الانتماء الوطني والانتماء القومي العربي

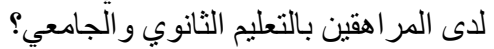

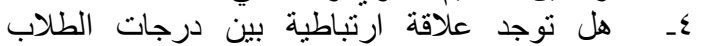

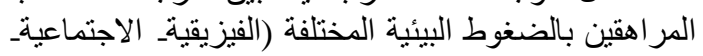

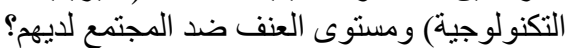

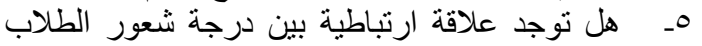

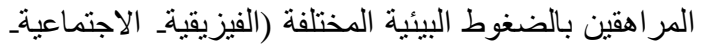
التكنولوجية) ومستوى الانتماء الوطني والقومية التئية العربي لايهز؟ آ- هل هل توجد فروق ذات دلالة احصائية بين متوسطات

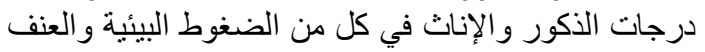

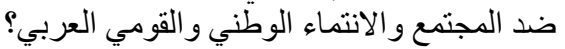

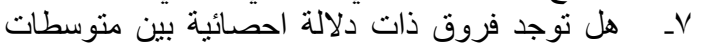
درجات الطلاب المر اهقين في المرحلة الثانوية والئ والمرحلة

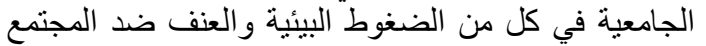
و الانتماء الوطني و القومي العربي؟

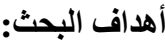

أـ التعرف على مستوى الضغوط البيئية المختلفة (فيزيقية.

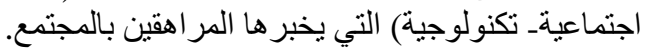

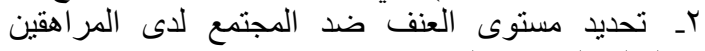
بالتعليم الثانوي و الجامعي. r- تحديد مستوى الانتماء الوطني و الانتماء القومي العربي

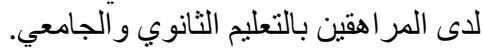

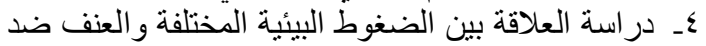

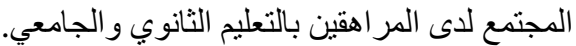

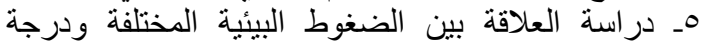

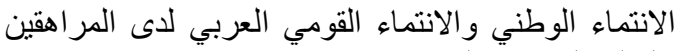

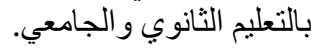

الاتزان الانفعالي والتوتر ونقص قدرتي الانتباه والتعلم،

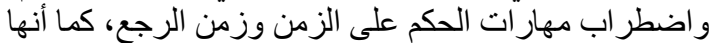

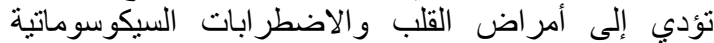

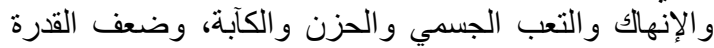

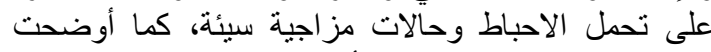

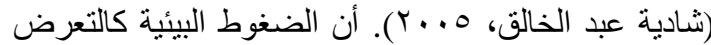

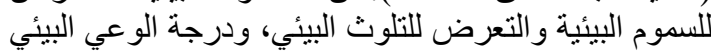

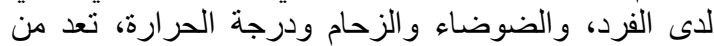

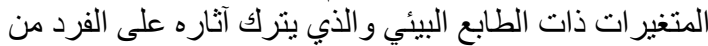

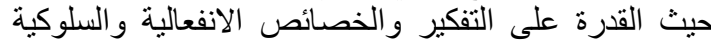
اللفرد بشكل بمكن قياسه وملاحظته (ص 9 ـ ـ ـ (1).

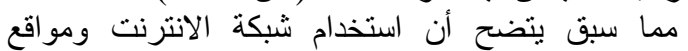

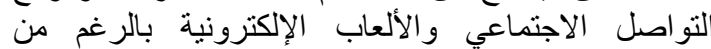

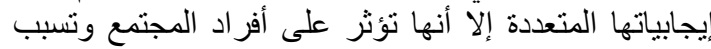

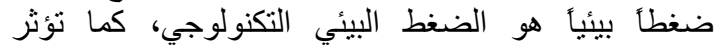

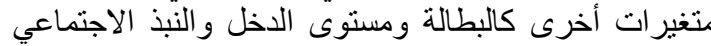
على أفراد المجتمع فيما يعرف بالضغن الضغط البيئي الاجتماعي،

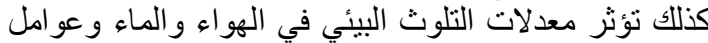

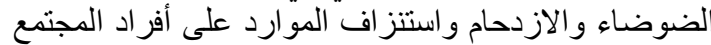

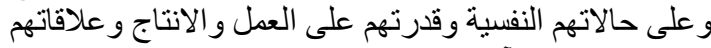

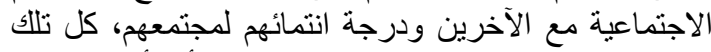

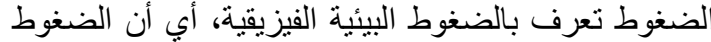

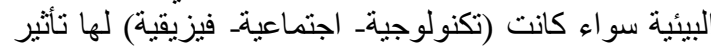

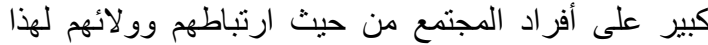

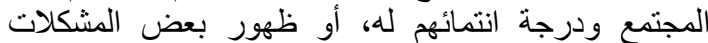

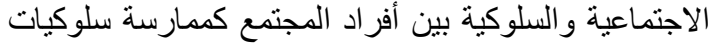
العنف و العدوان بين أفر اد الدجتمع. :

إن الضغوط البيئية سواء كانت (فيزيقيةــ اجتماعية.

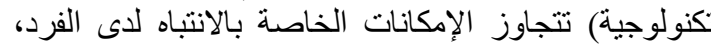

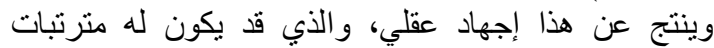

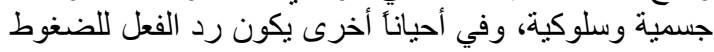

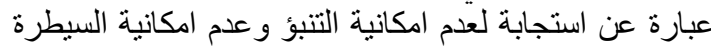

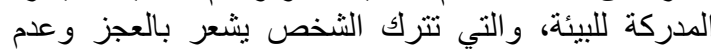
القدرة على مواجهة الموقف أو التعايش معاله، فالتنبيه الزائد

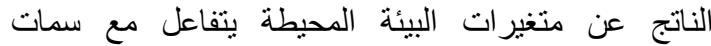

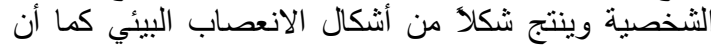
آلية التحكم في هذه الضغوط البيئية يمكن أن تؤثر في حدوث

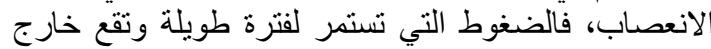

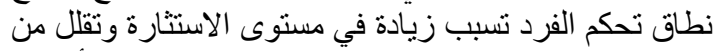

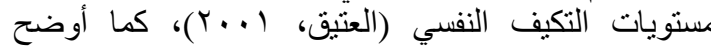

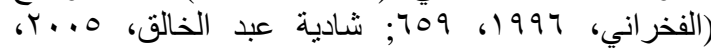

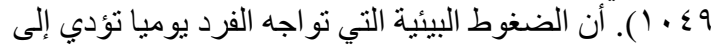

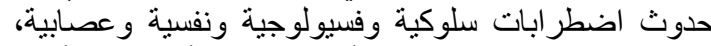
وتزيد من مستوى القلق لدى الأفر اد، ويترك أثناره على أفر ادلى

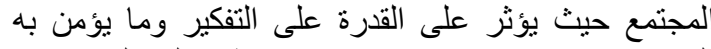

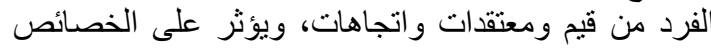

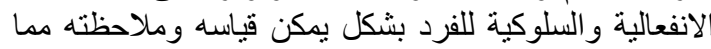
يجعل أفراد المجتمع فريسة سهلة للتبارات الفكرية الغريبة 


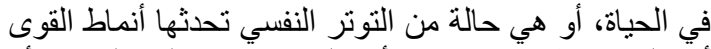

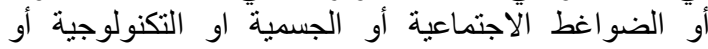

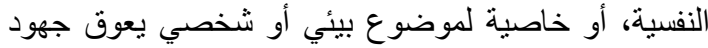

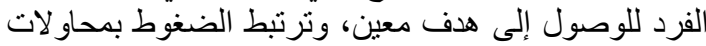

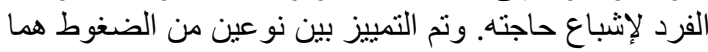

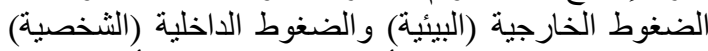

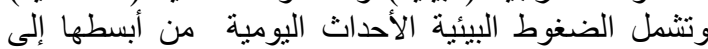

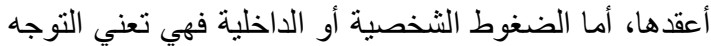

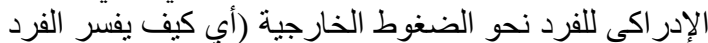

. بيئته و الأحداث) (Lazarus, \& Folkman, 1987) الضغوط البيئية: نعرفها الباحثة بأنها هي الثعور بالقوى (الثئي

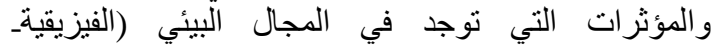
الاجتماعية- التكنولوجية) وتؤثر على الحئ الحالة النفسية للفرد،

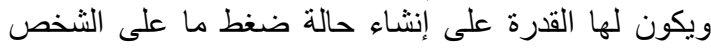

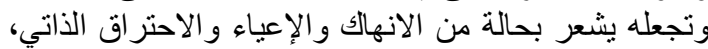

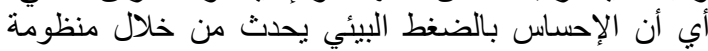

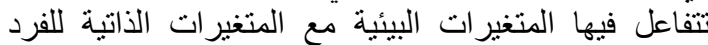
ليشعر الفرد في النهاية بأنها واقع تحت تأثير ضئنير ضغط.

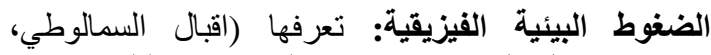

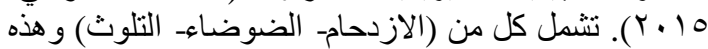

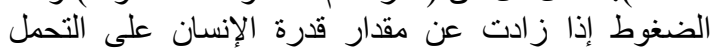

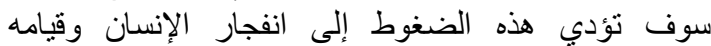
بسلوكيات سلبية متل العنف و العدو ان و غيره.

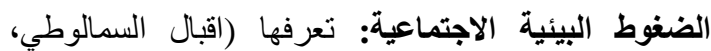

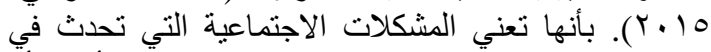

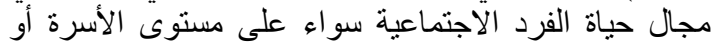
الدراسة أو العمل، وتتعلق بتفاعله مع الآخرين.

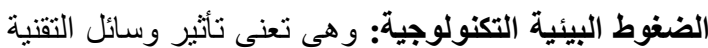

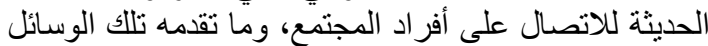

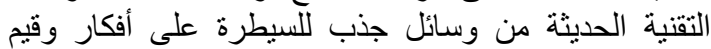
الأفراد ومن ثم التأثير والتحكم في سلوكياتهم. (بومعيزة) ( r...T

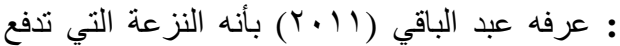

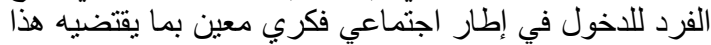

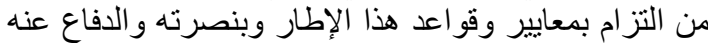

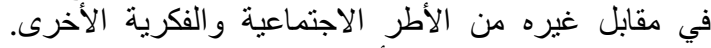

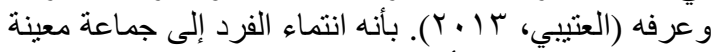

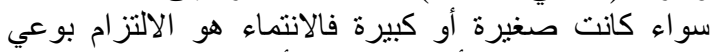
و الارتباط برحاب الأرض وضئ وحاجة أساسية في داخل الفراء الفرد،

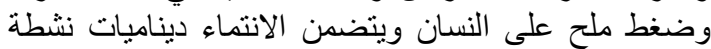

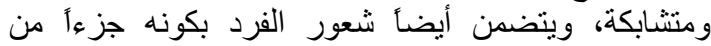

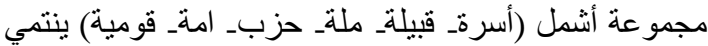

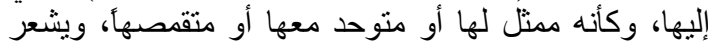

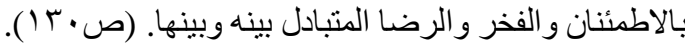

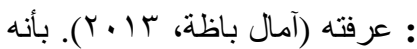

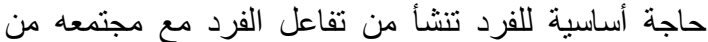

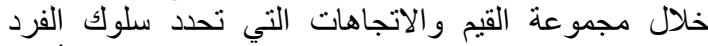

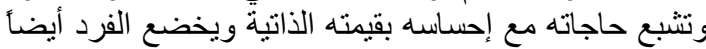
لمنطلبات الجماعة التي يعيش فيها مثل تحمل المسئولية النية

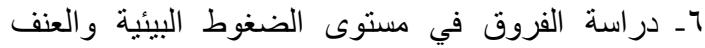
و الانتماء لدى المر اهقين و التي تعزى إلى اختلاف الجنس النس

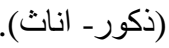

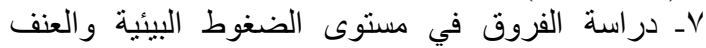
و الانتماء لدى المر اهقين و التي تعزى إلى الى اختلاف المرحلة

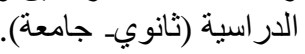

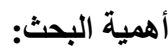

اـ قد تسهم هذه الدراسة في تتمية الجانب النظري لمتغيرات

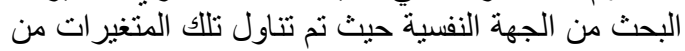
جو انب أخرى تربوية و غير نفسية.

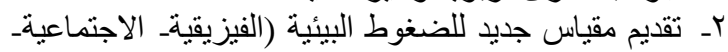

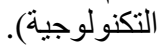

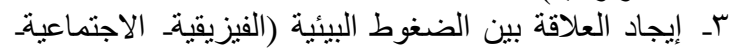

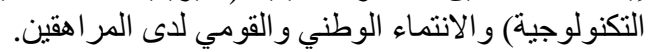

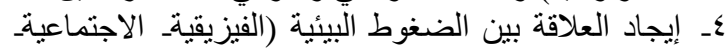

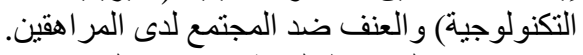

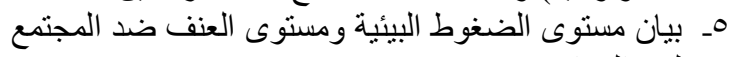

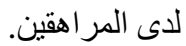

Tـ تحديد درجة الانتماء التي يثعر بها المراهقين للوطن

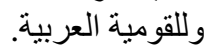

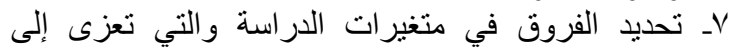
(الجنس- المرحلة الدر اسية).

^ــ دراسة متغيرات ذات تأثير على الجو انب النفسية للمر اهقين

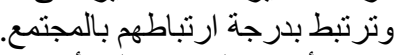

9ـ ترجع أهية الدراسة إلى أهنية الانتماء وخطورة تأثيره

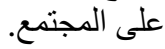

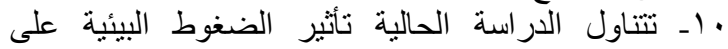

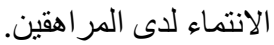

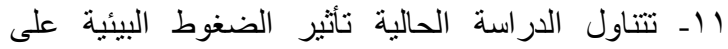
احتمالية ابر از ظاهرة العنف لدى الدالئ المر اهقين.

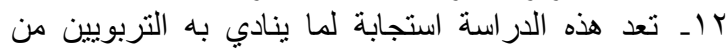

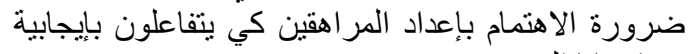

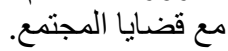

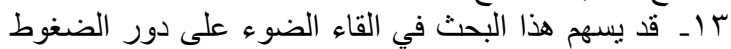

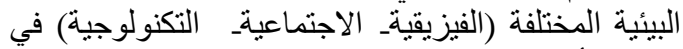
انتماء الأفر اد للمجتمع، واحتمالية نمو ظاهرة العنف لديهم.

\section{:}

ـ حدود بشرية: طبق هذا البحث علي المر اهقين من طلبة

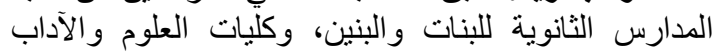
و المجتمع للبنين و البنات بمحايل عسير.

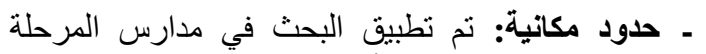

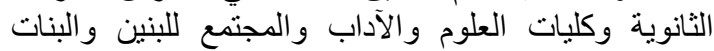
بمحايل عسير بالمملكة العربية السعودية.

ـ حدود زمانية: طبق البحث في الفصل الدراسي الأول من التربة

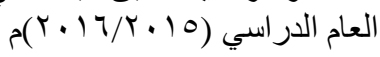
:

: هي إحدى ظواهر الحياة الإنسانية، التي يخبرها

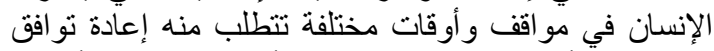

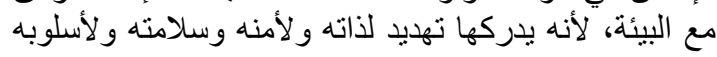


: الضفوط البيئية الفيزيقية: سواء كانت (ازدحام أو

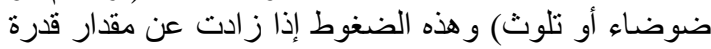

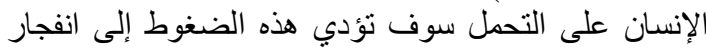
الإنسان وقيامه بأعمال العنف.

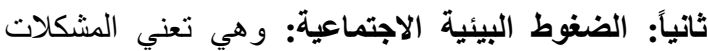

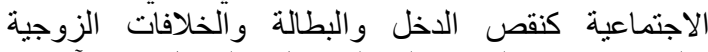
و التضخم وعدم القدرة على التواصل والطل والتفاعل مع الآخرين ومقابلة الغرباء و النبذ الاجتماعي و الحرمان و الإحباط.

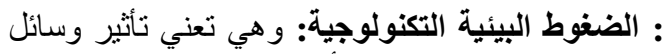

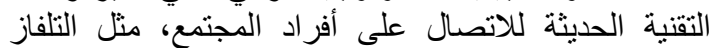

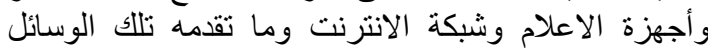

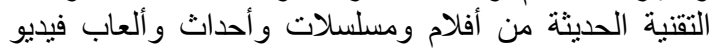

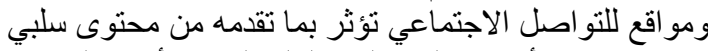

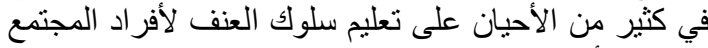

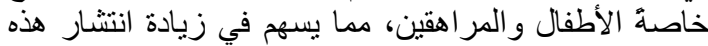
الظاهرة ومن ثُم يؤثر على انتماء الأفر اد لمجتمعهم.

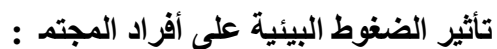

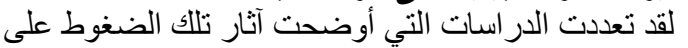

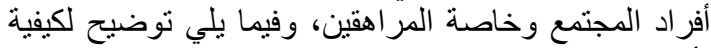
تأثير الضغوط البيئية (الفيزيائيةــ الاجتماعيةــ التكنولوجية) على أفر اد المجتمع. : تأثير الضغوط الفيزيائية: أثارت (شادية عبد الخالق،

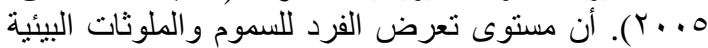

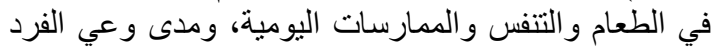

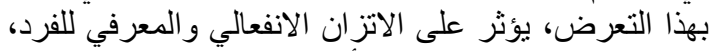

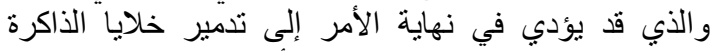

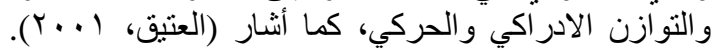

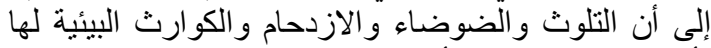

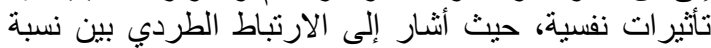

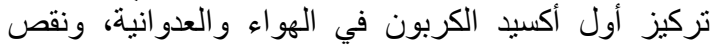

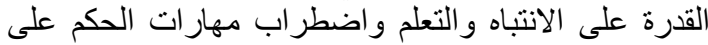

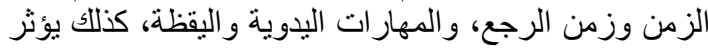

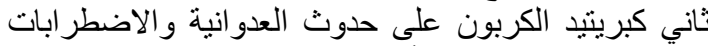

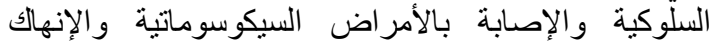

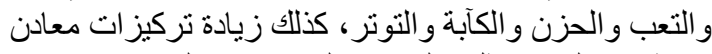

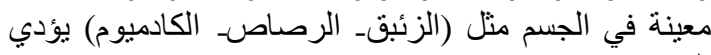

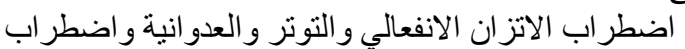

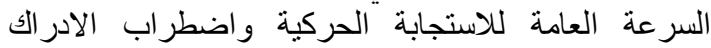

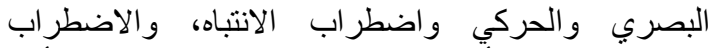

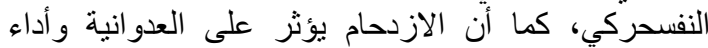

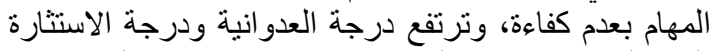

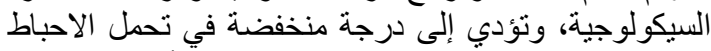

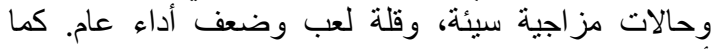
أوضح الارتباط بين الضغوط البيئية المختلفة ونمط الثخصية الثراية

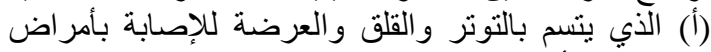

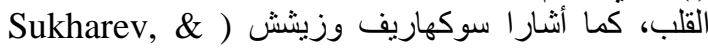
(Zschech, 2011

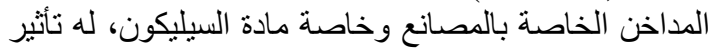
كبير على إحساس الفرد بالضغوط المحيطة به، وبقدرنه على نلى
و العدل والحب الجاد وغير ها لبعطي للجماعة الاستمر ارية

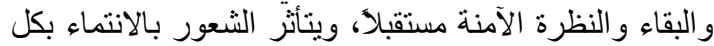
المتغير ات السياسية و الاجتماعية والاقتصادية للمجتمع ككل.

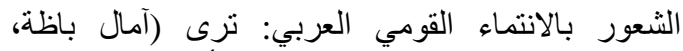

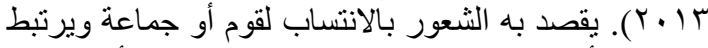
بالجماعة أو القوم بصلات اجتماعية وعاطفية تنتشأ من اللغة ولئة

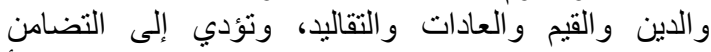
و التعاون و التفاهم للاحتياجات مثل القومية العربية، و وهي مبدأ

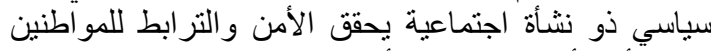

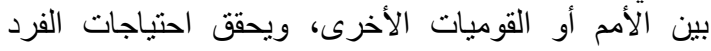

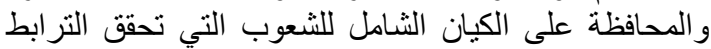

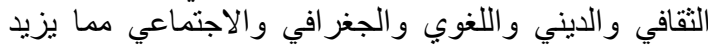

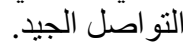

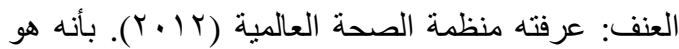
الاستعمال المتعدد للقوة الفيزيائية (المادية) أو القدرة سواء

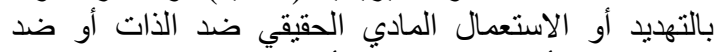

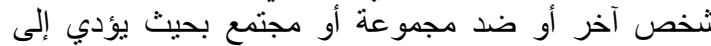

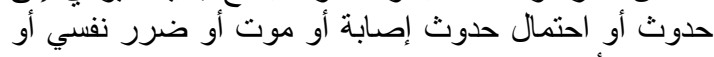

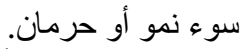

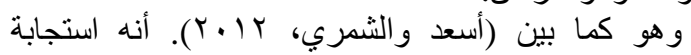
سلوكية تتميز بصفة انفعالية شديدة قد تنطوي بلى على انخفاض

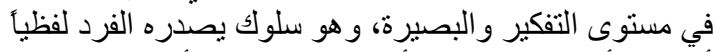

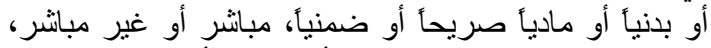

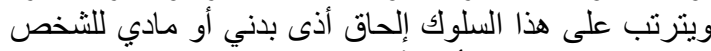
نفسه صاحب السلوك أو للآخرين.

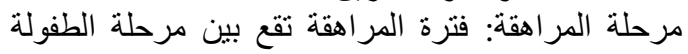

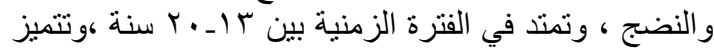

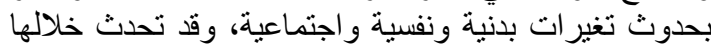
بعض الاضطر ابات النفسية و السلوكية (الدسوقي، وند 1991) .

: الضغوط البيئية: Environmental Stress بين البين

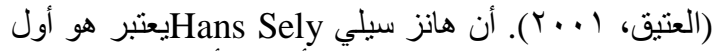

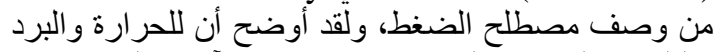

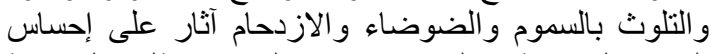

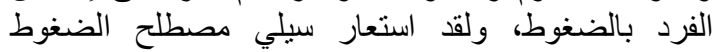
Stress

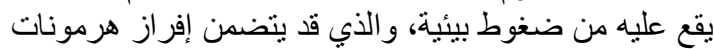
وتثبيط أخرى، وقد أثشار سيلي إلى أنى استجابة الناس

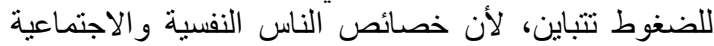

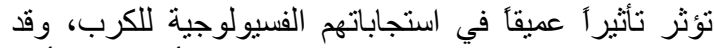

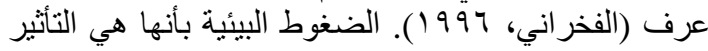
الفيزيقي على إحساسات الفرد وبالتالي يمكن تعريفها على الثى

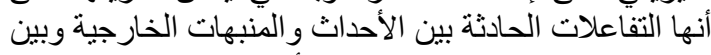

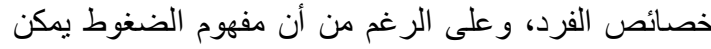
تعريفه نظريأ على إنه مفهوم تفاعلي إلا إنه يمكن قياسه عن النه طريق التقديرات الكمية من قبل الفرد لمثل هذه الأحداث (الحساسية للأحداث).

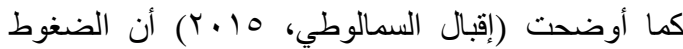
البيئية تختلف لتنمل أنو اع متعددة هي: 


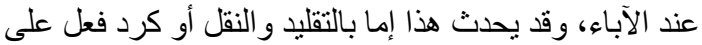

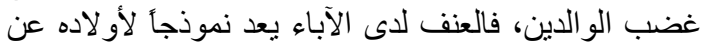

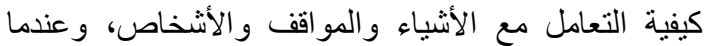

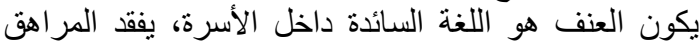

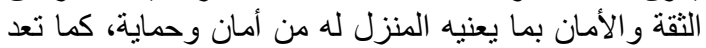

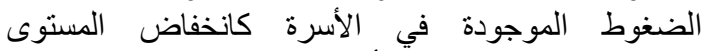

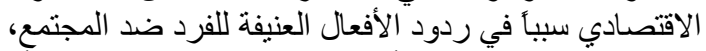

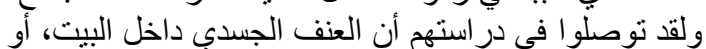

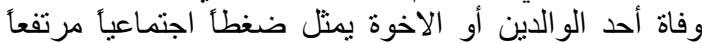

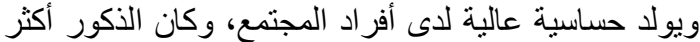
تأثرا بتلأك الضغوط الأسرية.

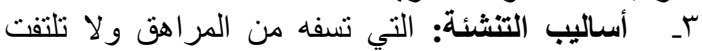

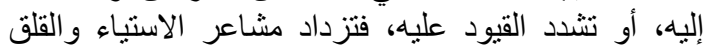

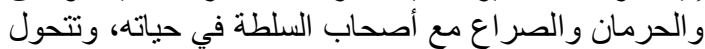
الدسألة إلى صراع ماعر من أجل إثبات الذات ويشعر المراهق

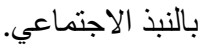
عـ- إحساس المراهق بالظلم والحرمان والإحباط: من أكثر

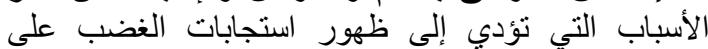

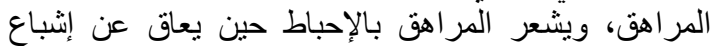

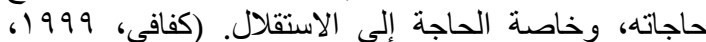

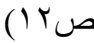
هـ النواحي الاقتصادية: حيث تعد من أكثر الضغوط المؤثرة

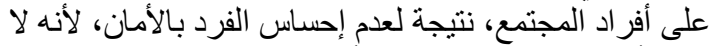

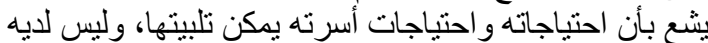

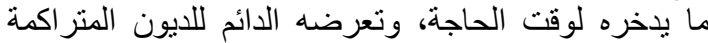

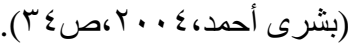

ـ كذلك عدم الإحساس بالاستقلالية والاحترام والتزام

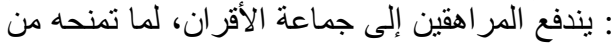

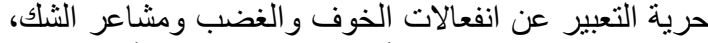

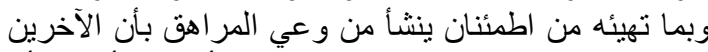

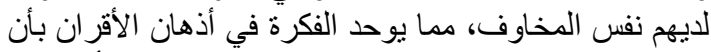

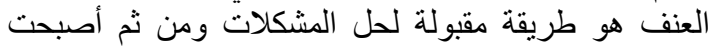

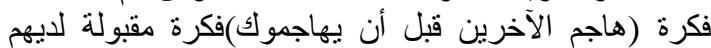

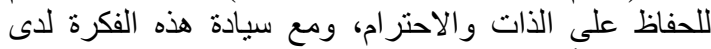

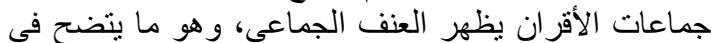

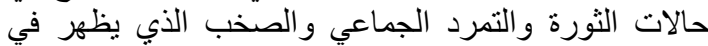

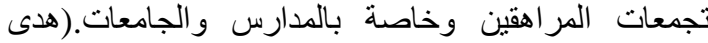

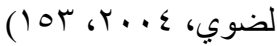

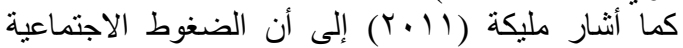

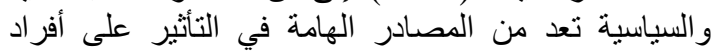

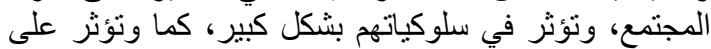

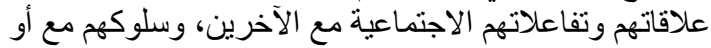
ضد المجتمع، وتحدد درجة التمائهم للجماعة الأنة

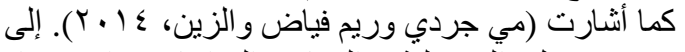
أن عدم تحمل ألمسئولية والفساد والنئ والنزاعات والزين والاستخدام

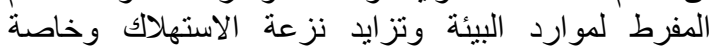

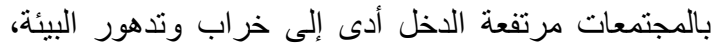

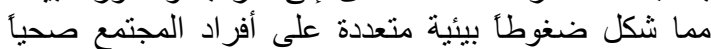

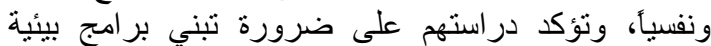
لتخفيض أثر هذه الضغوط البيئية على أفراد المجتمع مثل بنل

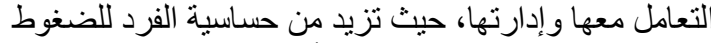

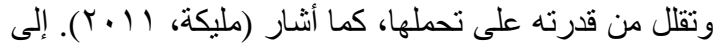

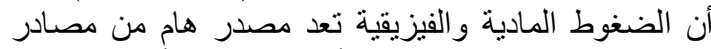

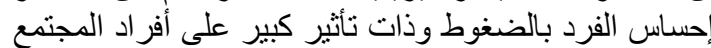

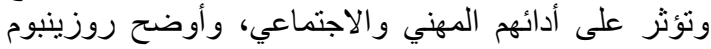

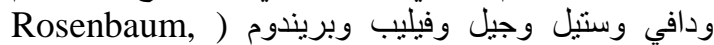
أن أن (Davy, Steel, Jill, Philip,\& Brendon, 2015 الأشخاص الذين تعرضوا لضغوط الضوط عالية من جر اء التعرض

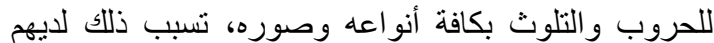

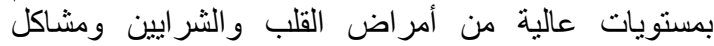

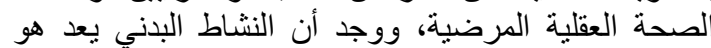

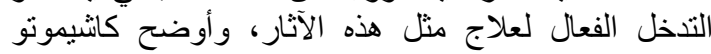

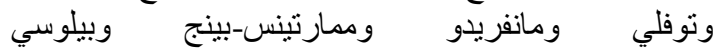
Kashimoto, Toffoli, Manfredo, Martins-) (Pinge\&Pelosi, 2016

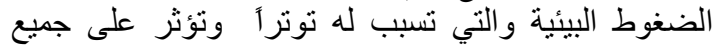

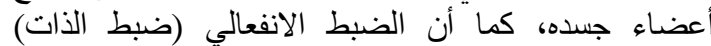

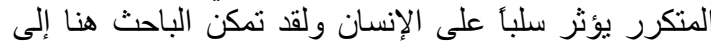

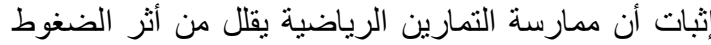

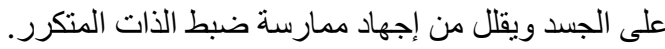

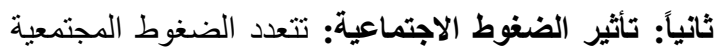

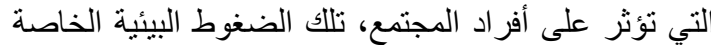

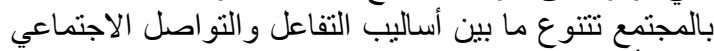

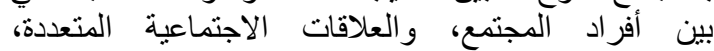

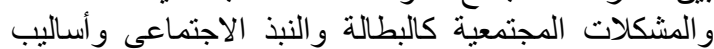

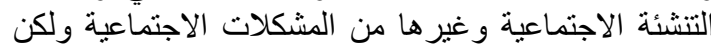
يتم التركيز في هذه الدراسة على المئية المكلات الاجتماعية

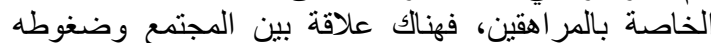
المتعددة وظهور العنف بين أفر اده، وخاصة بين بين المر اهقين،

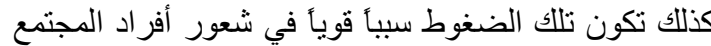

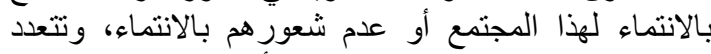

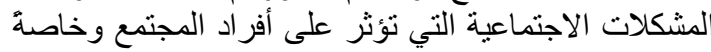

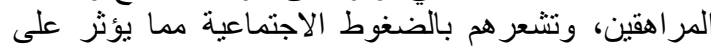

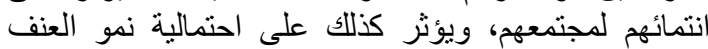

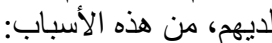

- ـ اسليب المعاملة مع المراهقين من أفراد المجتمع:

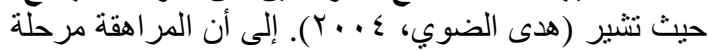
خصبة لنمو سلوكيات العنف، ويجب على على الكبار الكبار القيام بمساعدة المر اهقين على تخطي هذه المرحلة بأمان و التخفيف

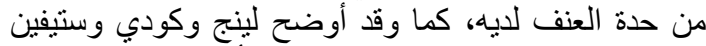
(Ling, Cody, \&Steven, 2013)

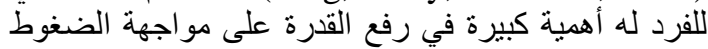

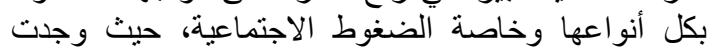

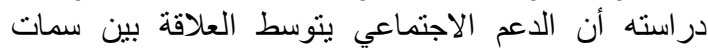
الثخصية والقدرة على الدعم الذاني وبين شعور الفردية بين الفرد

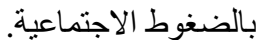

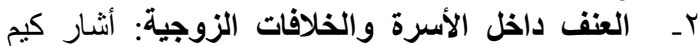
و إنجا وجون وجيسلي ) Kim, Inga, Jon,\& Gisli, 2016). أن الخلافات الزوجية تعد نموذج في العنف المتبادل

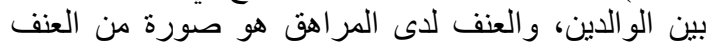




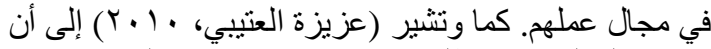

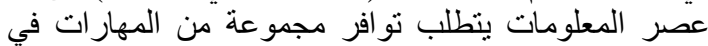

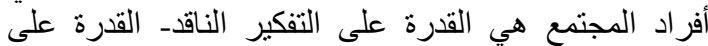

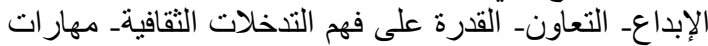

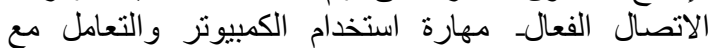

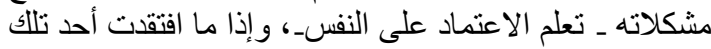

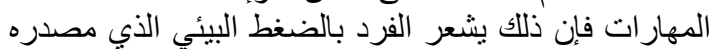

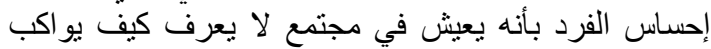

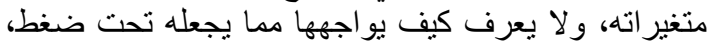

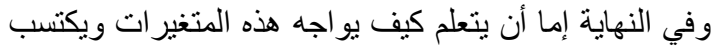

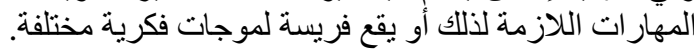

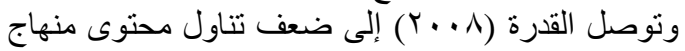

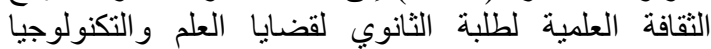

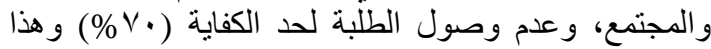
دليل على انخفاض في مستوى فهم الطلبة لقضايا العلم

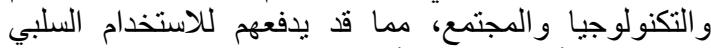

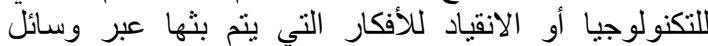

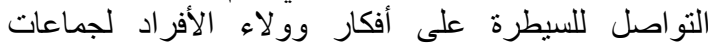

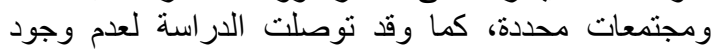

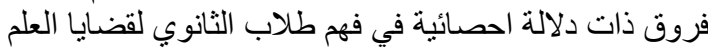

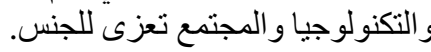

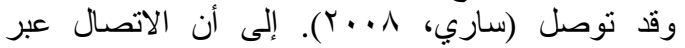

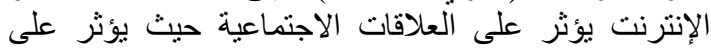

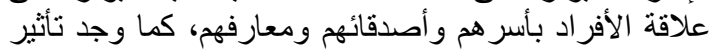
للإِنترنت في نسق التفاعل الاجتماعي بين أفراد التئر العينة وبين

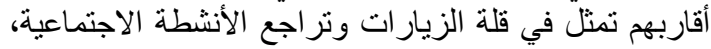

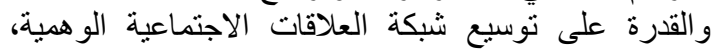

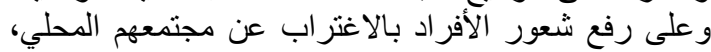

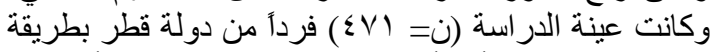
عشو ائية، وقد تبين أن تأثير الإنترنت في الإناث كان أكثر من تأثيره في الذكور. وأثنار جيميل وبيترسون (2007) Geterson, 2006). إلى أن استخدام وسائل التكنولوجيا الحديثة كان له

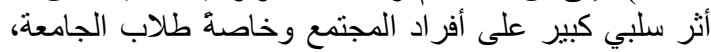

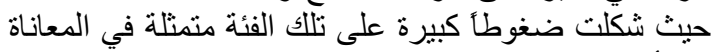

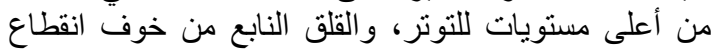

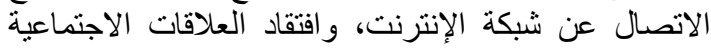

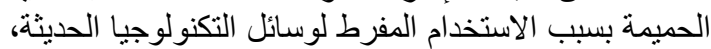

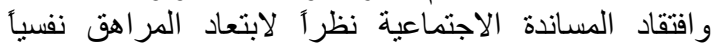

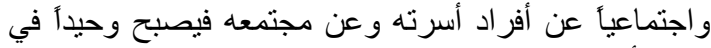

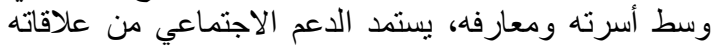

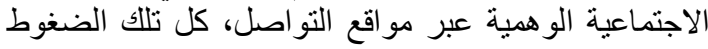

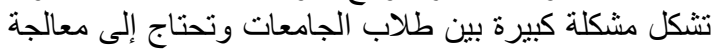
من قبل المهتمين بشئون الطالبات. كما و أثنار تيواري و آنجيو و إندر اماني ( Tiwari, Anju, كمان

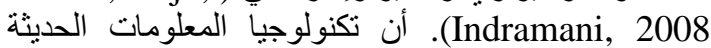
تصنع ضغوطاً على أفراد المجتمع، وقد تعددت الدراستات التهات

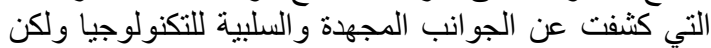

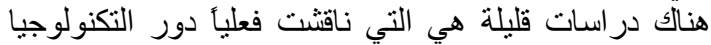

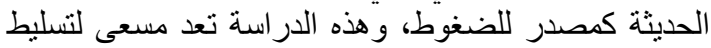
الضوء على إيجابيات وسلبيات استخدام التكنولوجيا الحديثة،
برامج التصدي لندرة الموارد البيئية كالماء وتعليم كيفية ترشيد استخدامه، وبرامج إنقاص استهلاك المواد الدواد المستنفة

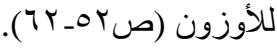

: تأثير الضغوط التكنولوجية: أثنار (صالح، 1991).

إلى أن الضغوط التكنولوجية تعني فقط النتائج السلبية لعملية

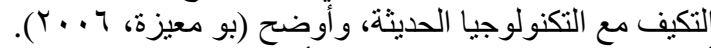

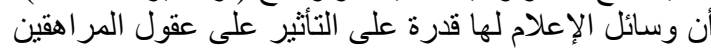

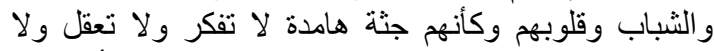

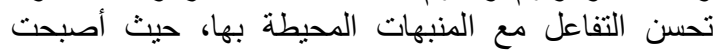
تخترق جميع مجالات الحياة وكل بيت، وأضحت الضيت وسائل

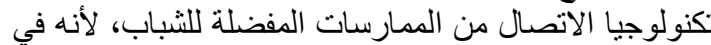

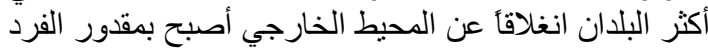

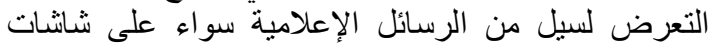

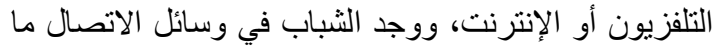

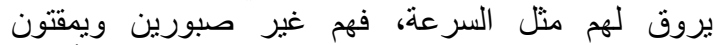

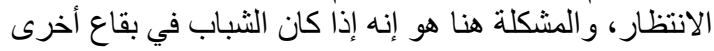

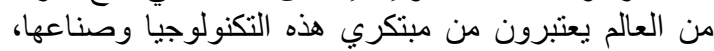
فإن الثباب العربي ييقون مستهلكين لها وحسب، لانكان لانعدام

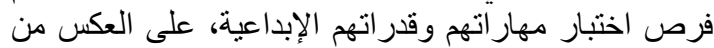

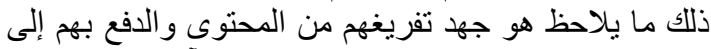

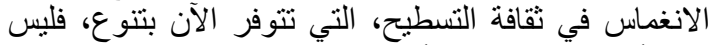

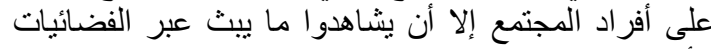

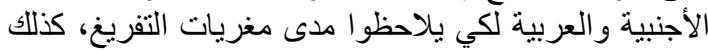

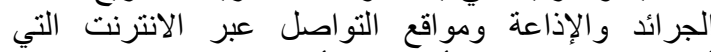

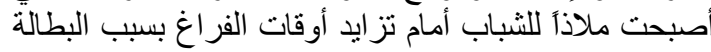

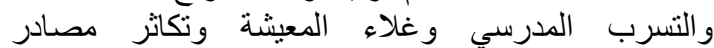
الاستهلاك، كل ذللك شكل ضغطأ بيئيا تكنولو وجياً و اجتماعياً

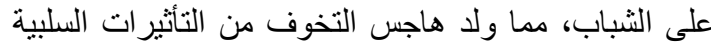

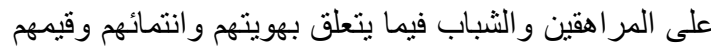
وسلوكياتهم، التي كانت فوق الثبهات قبل مجيء تكنولوجيات ولتئ

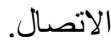

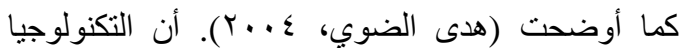

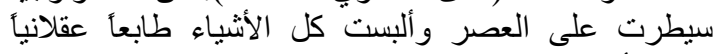

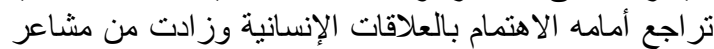

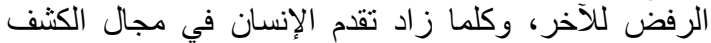

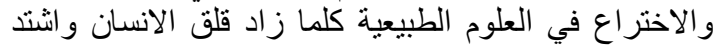

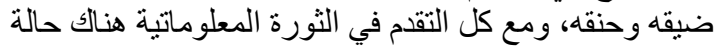

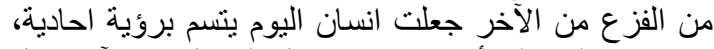

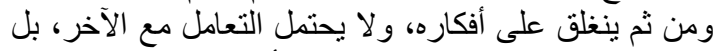

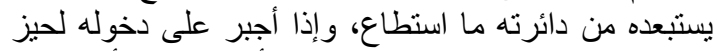

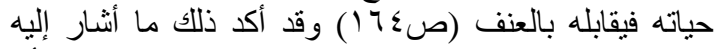

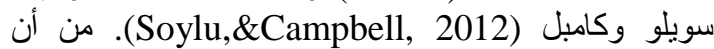

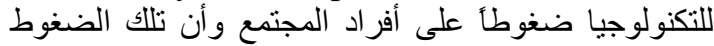

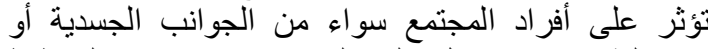

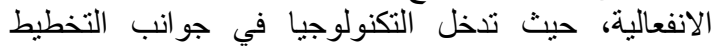
و التنظيم و التوظيف و القيادة و السيطرة على النى وظائف إلى إدارة الموارد البشرية، ولقد أثبتا في دراستهم أن الأفراد الأكثر

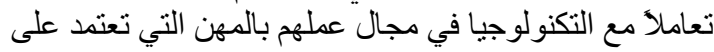

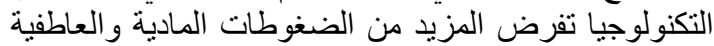
والجسدية عليهم أكثر من الأفر اد الأقل استخدامأ للتكنولوجيا 
الجهاز العصبي الذاتي إلى أن يرجع الجسم إلى حالة التوازن

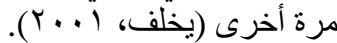

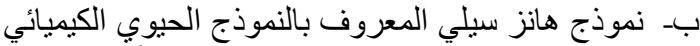

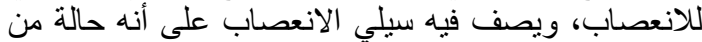

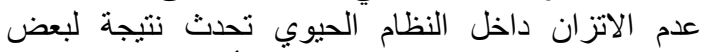

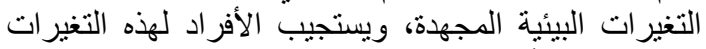

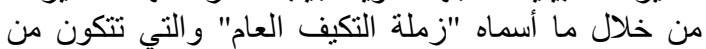

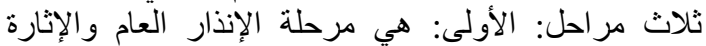

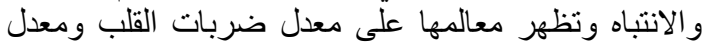

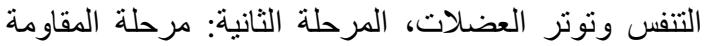

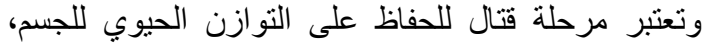

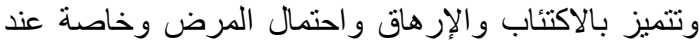

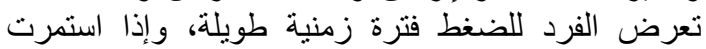

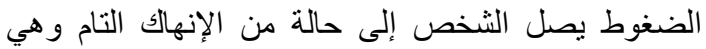
المرحلة الثالثة والتي قد يكون لها آثنار سلبية على الإنى الجسم كله الته

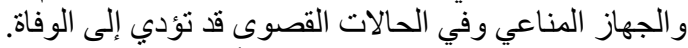

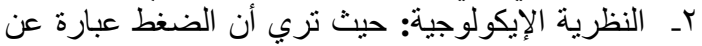

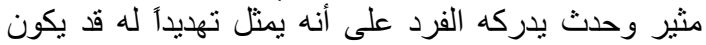
منشأه داخلياً كالصر اعات النفسية، كما قد ينشأ من الأحداث

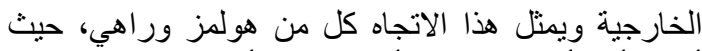

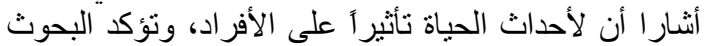

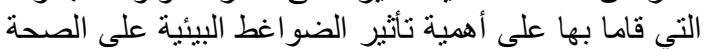

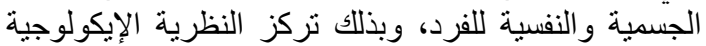

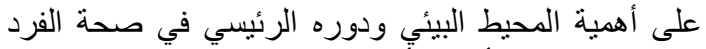

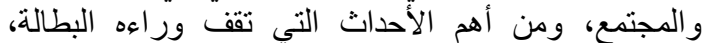

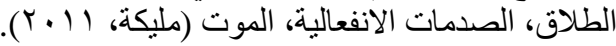

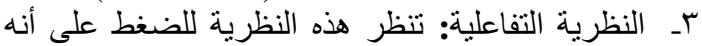

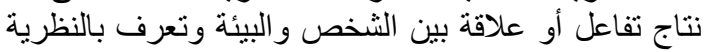
فقد

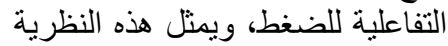

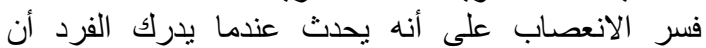

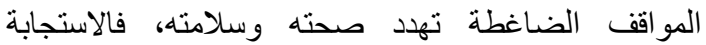
للمواقف الضاغطة (الانعصاب) تحدث كنتيجة لتقييم الفرد

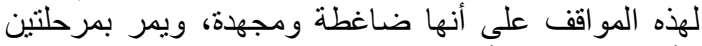

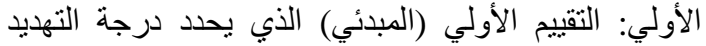

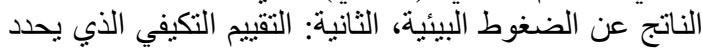

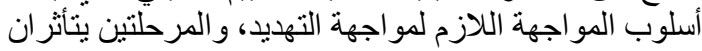

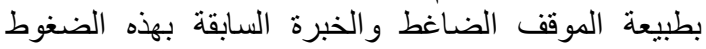

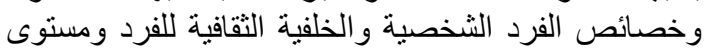

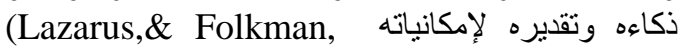

عـ ـ وهناك نموذج جرين الذي حدد ثناث جوانب رئيسية

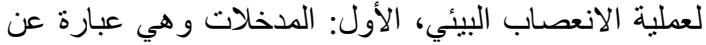

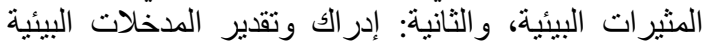

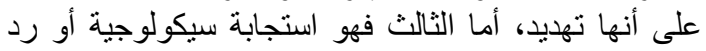

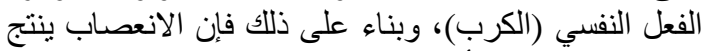

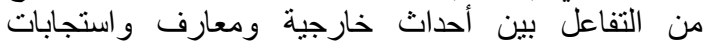

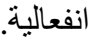

0ـ وهنالك نموذج فرنش لتفسير الانعصاب البيئي من خلال

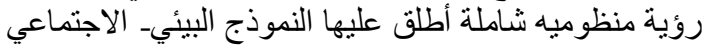

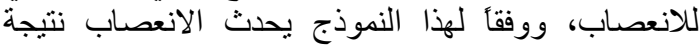

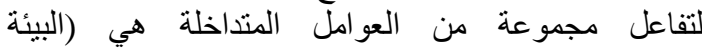

بغرض الوقوف على تللك الايجابيات والعمل على تنمينها

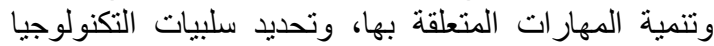
لتجنبها ورفع و وعي الأفر اد بهذه السلبيات حرصاً على تجنيها. كما أثشار بارك وسونج ومين لي ) Park, Song\& Min

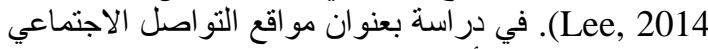

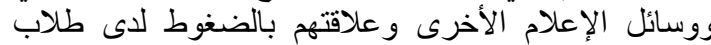

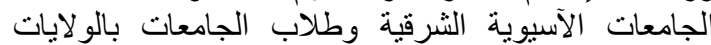

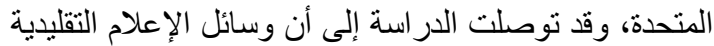

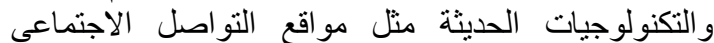

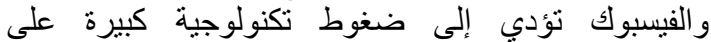

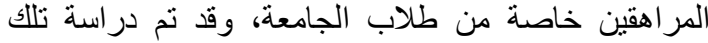
الارثباطات على عينات مختلفة من طلاب الجناب الجامعات الكورية

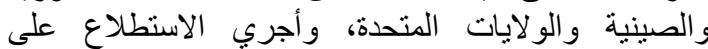

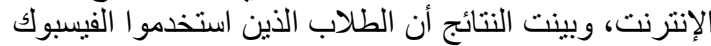

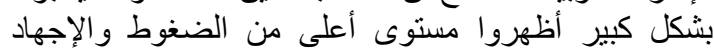
ودرجة أقل في الانبساط من أقرانهم الذين لم لمن يستخدموا

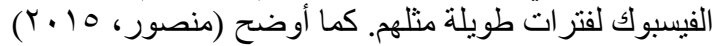

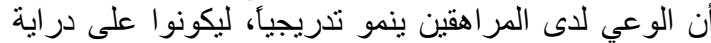

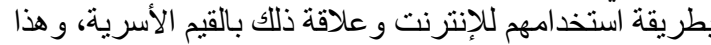
يفسر الاندفاع في استخدام الإنترنت في المرانة اهقة المبكة فيكرة

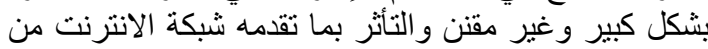

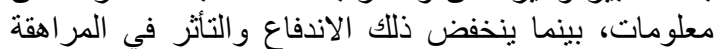

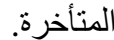

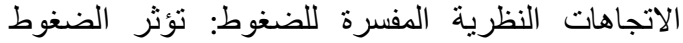

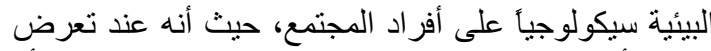

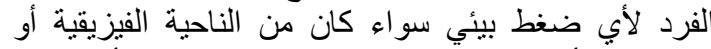

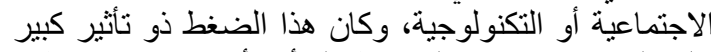

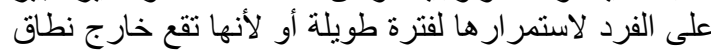

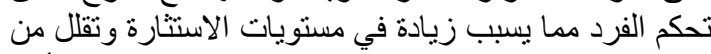

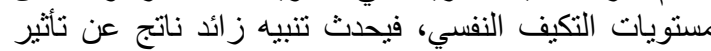

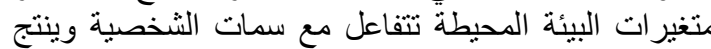

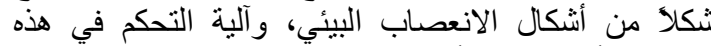

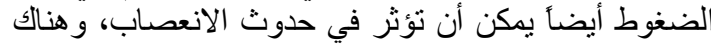

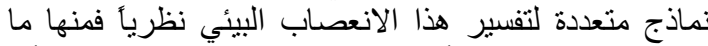

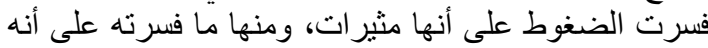

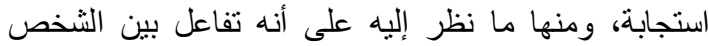

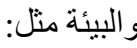

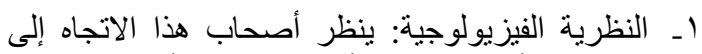

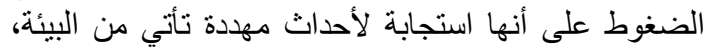

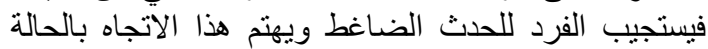
الاخلية للفرد، و أهم نظرياته:

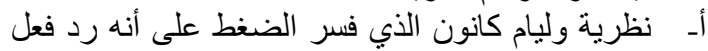

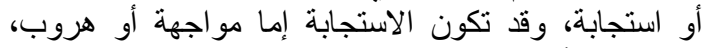

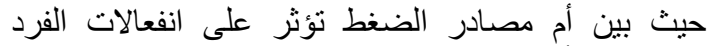

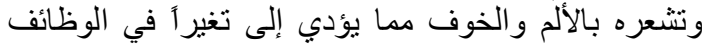

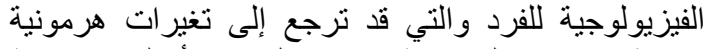

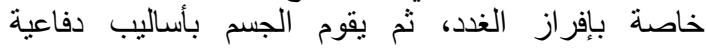

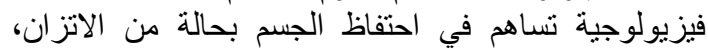

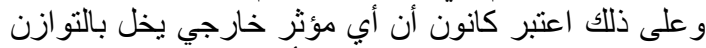

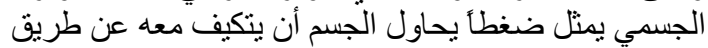




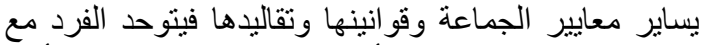

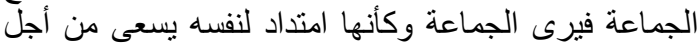

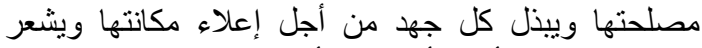
بالفوز إذا فازت أو بالأمن كلما أصبحت آمنة. (عبد الباقي،

. ( 1 .

ولقد أثنار تاهريه وآخرون (Tahereh, et. al., 2015)

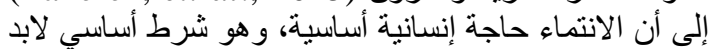

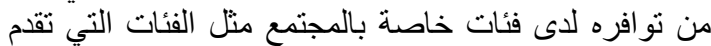

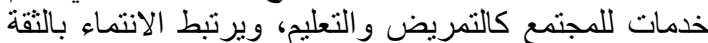

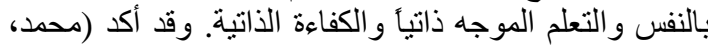

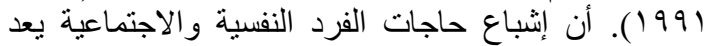

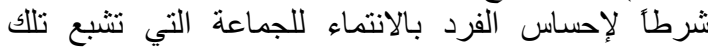

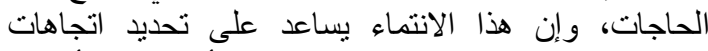

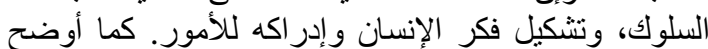

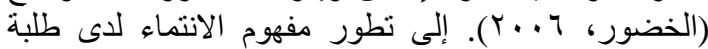

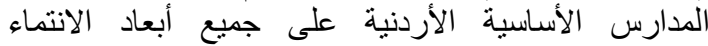

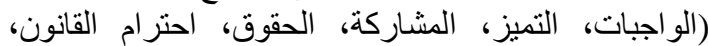

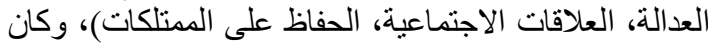

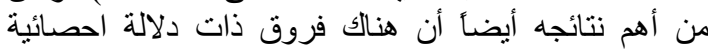

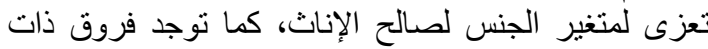
دلالة احصائية تعزى لمتغير اختلاف فطاع التعاف التعليم (الخاص،

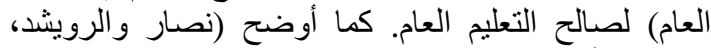

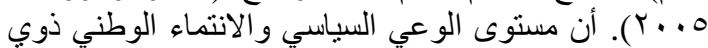

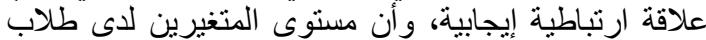

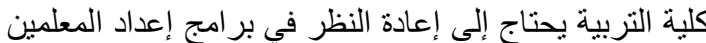

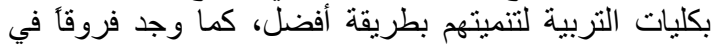

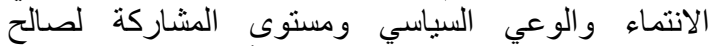

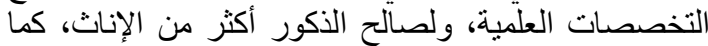

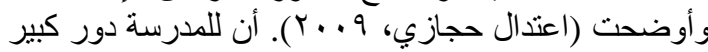

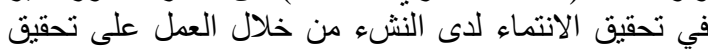

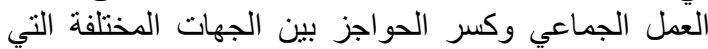

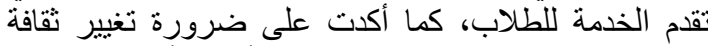

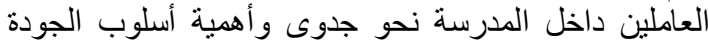

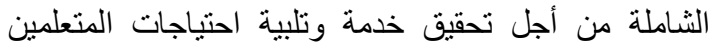

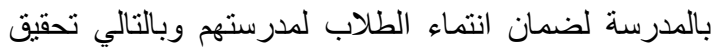

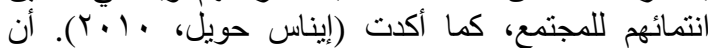

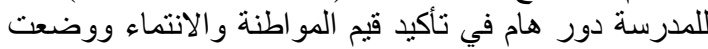

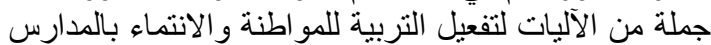

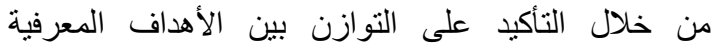

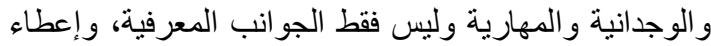

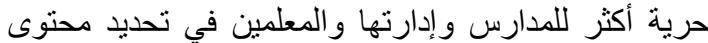

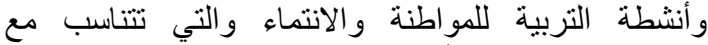

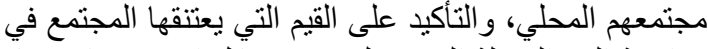

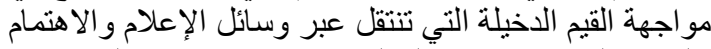

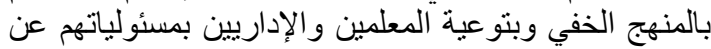

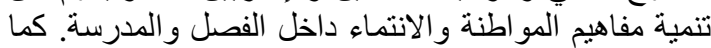

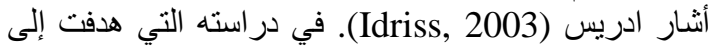

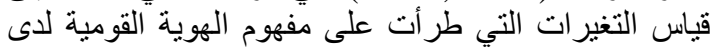

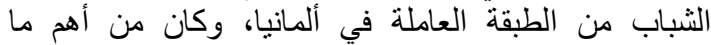

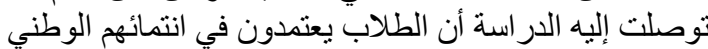
على الإرث الأخلافي، على الرغم من التفتح الظاهري لتقبل
الموضوعية: ويقصد بها التأثير الفعلي للبيئة الخارجية على لئى

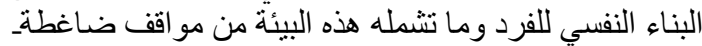

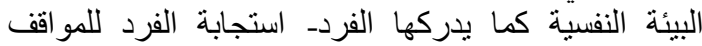

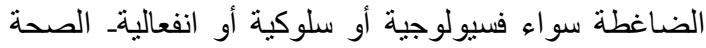

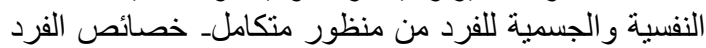
الوراثية و الديموغر افية والثخصية لفية العلاقات الاجتماعية

لالفرد).

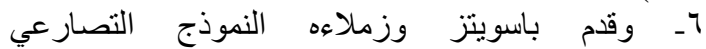

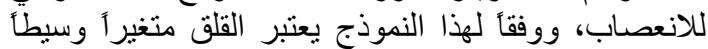

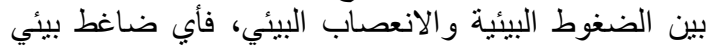

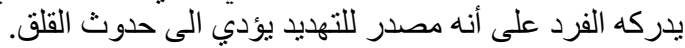

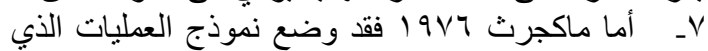

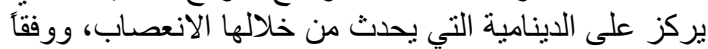

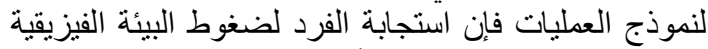

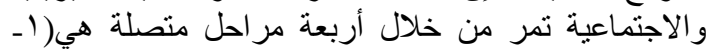

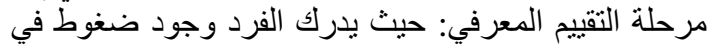

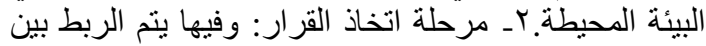

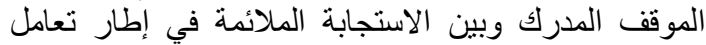

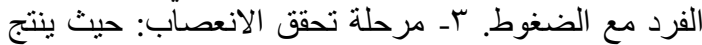

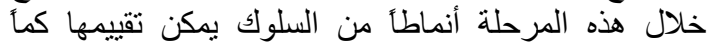

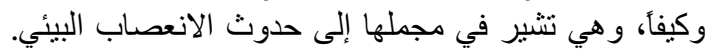

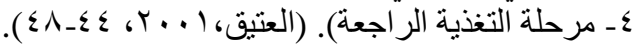

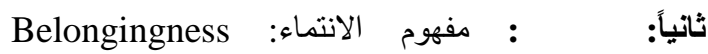
هو حاجة من الحاجات النفسية والإنسانية (Affiliation)

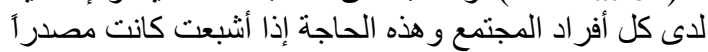

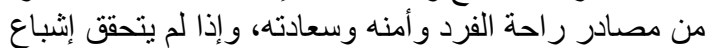

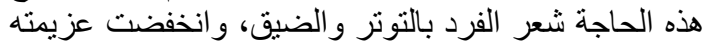

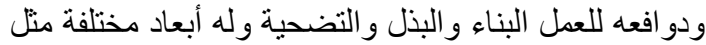

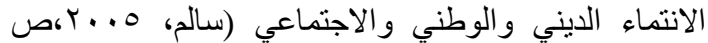
. (90 ولقد أوضحت (نجلاء راتب، 999 (199). أن الانتماء للوطن

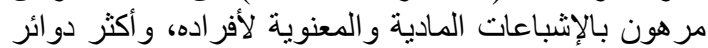

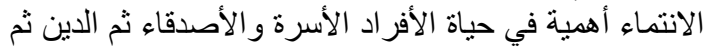

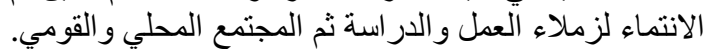

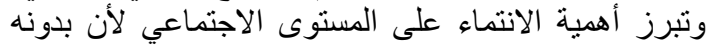

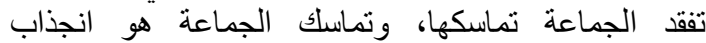

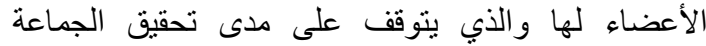

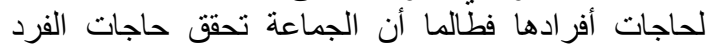

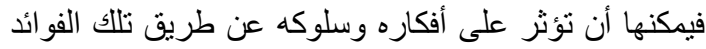

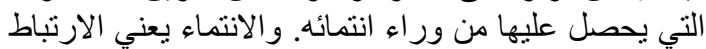

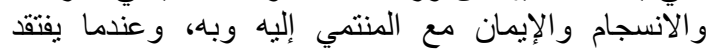

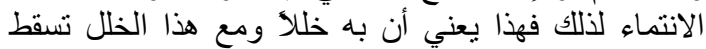

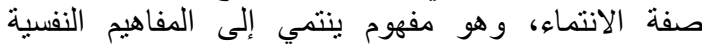

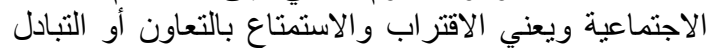

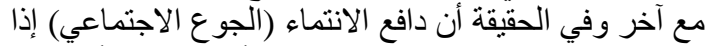

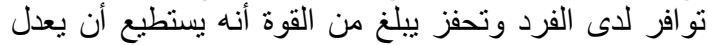

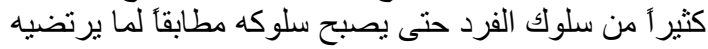

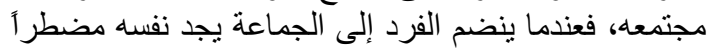

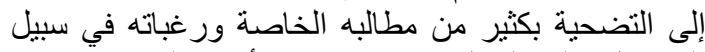
الحصول على القبول الاجتماعي من أفراد الجماعة وتجده 
الثقافي السائد، أما إذا لم يتوفر دافع الانتماء يصبح الفرد في

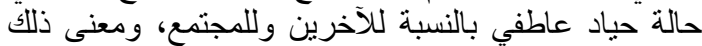
إما أن ينحصر اهنمامه في ذاته أو أو يصبح في في حالة وكالة ركود

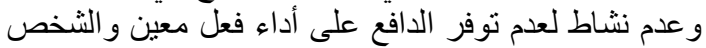

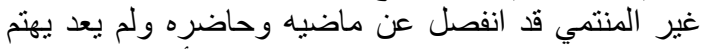

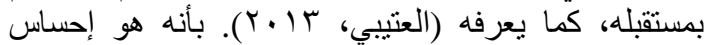

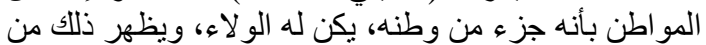

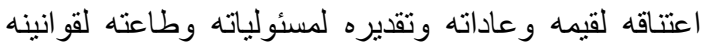

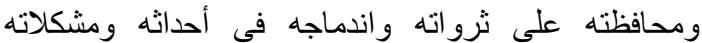

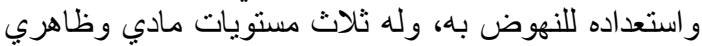

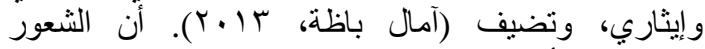

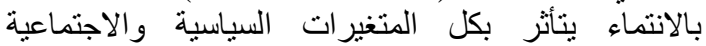

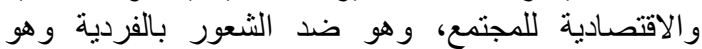

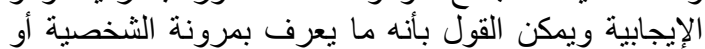

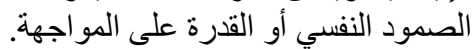

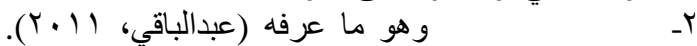

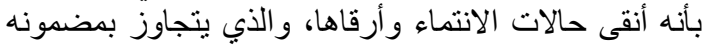

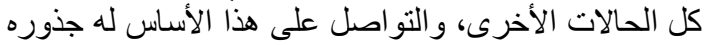

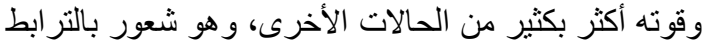

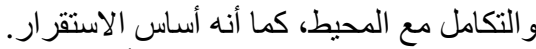

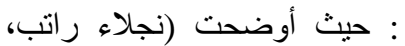
1999 (199). إن الثعور بالانتماء للمجتمع من أهم دعائم

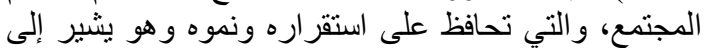

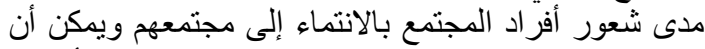
نستدل على ذلك من خلال المل المشاركة الإيجابية في أنشطة

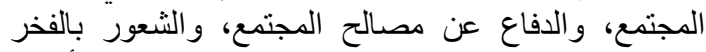

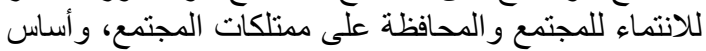

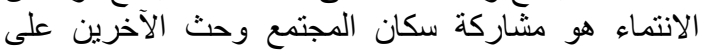

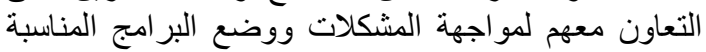

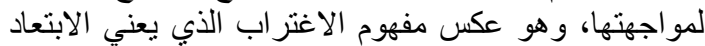

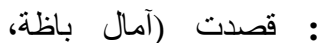
النفسي للفرد عن ذاته و وعن جماعنه.

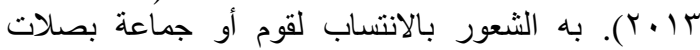

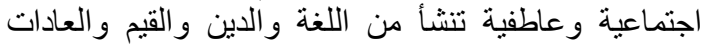

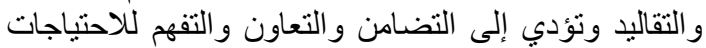

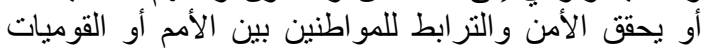

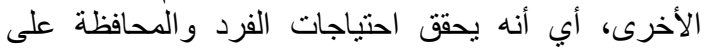

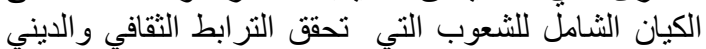

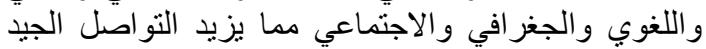
و هذا يجعل الفرد يقدم التعاون و التضحية و الفخر و العزة بها.

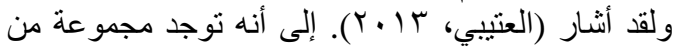

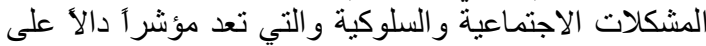

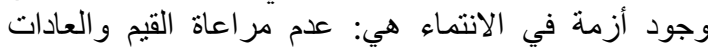

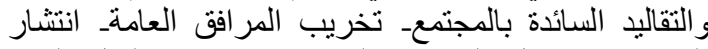

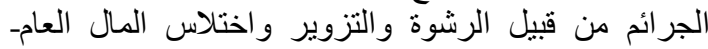

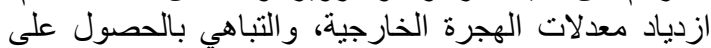

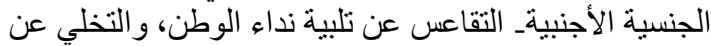

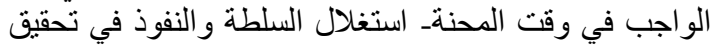

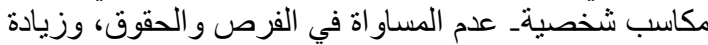

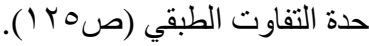

الاختلاف، كما بين جونسون (Johnson, 2009). العلاقة

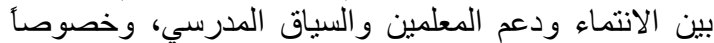

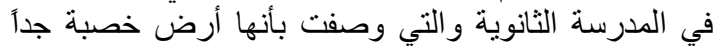

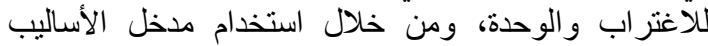

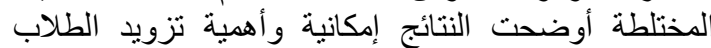

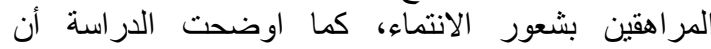

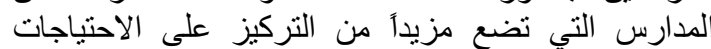

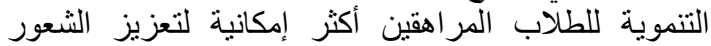
بالانتماء لديهر.

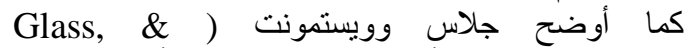

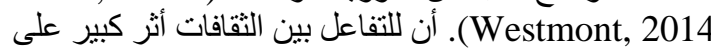
تحقيق النجاح الأكاديمي والثعور بالانتماء، حيث قام بتطبيق الثاني

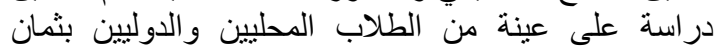

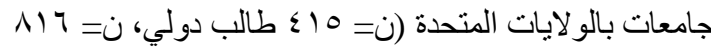

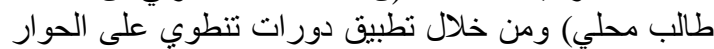

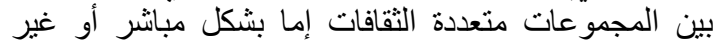
مباثر عبر شبكة الإنترنت بغرض إندات إيجاد تفاعل أكبر بين

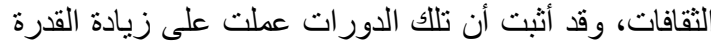

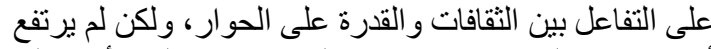

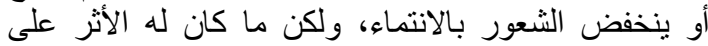

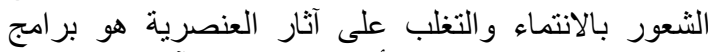

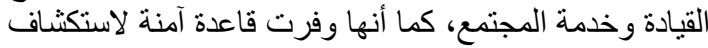

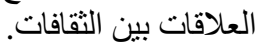

النظريات المفسرة للانتماء:

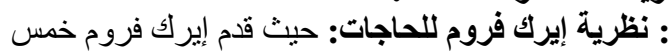

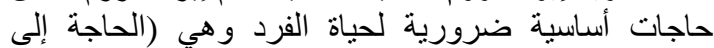

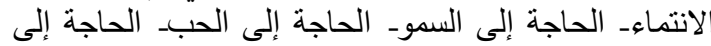

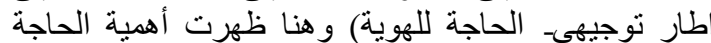

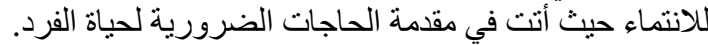
ثانياً: نظرية الحاجات لإبراهام ماسلو: حيث فلثة قدم ماسلو

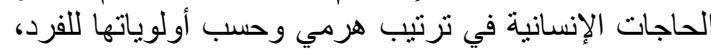

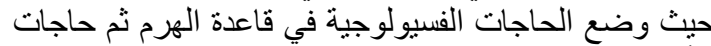

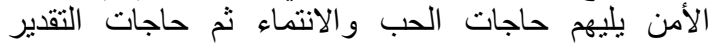

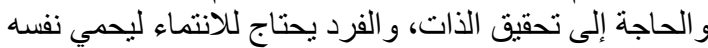

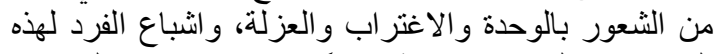

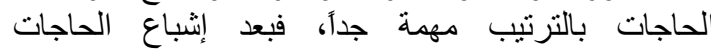

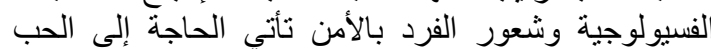
والانتماء ثم التقدير ثم تحقيق الذات.

: نظرية موراي للحاجات: حيث بنظر الى الحاجة بأنها

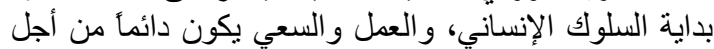

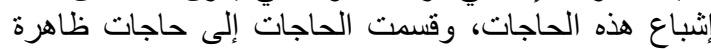

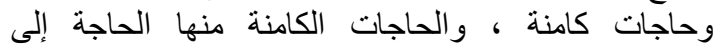

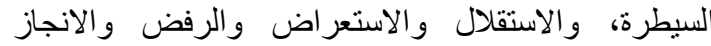

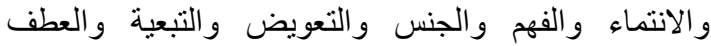

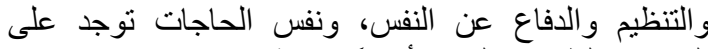

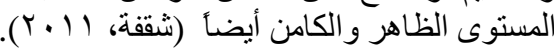

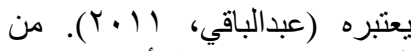
:

أوضح نماذج التوحد مع المجتمع حيث يلاحظ تأثير شخصية

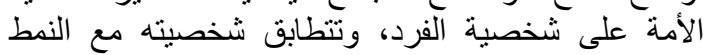




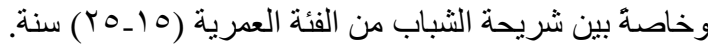

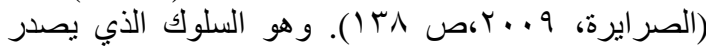

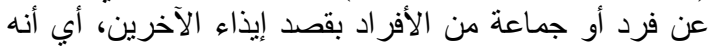

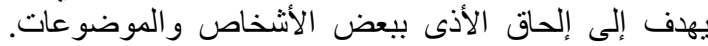

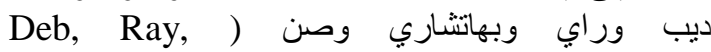
(Bhattacharyya\& Sun, 2016

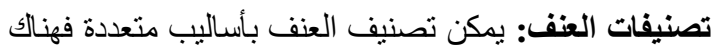

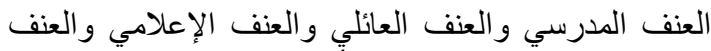

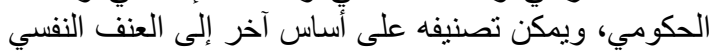

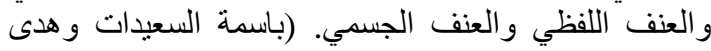

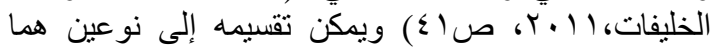

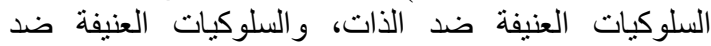

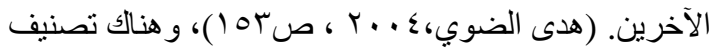
آخر للعنف إلى عنف نفسي وبدني وجنسي. ديب و وآخرون

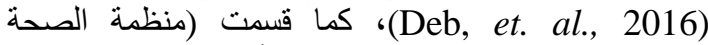

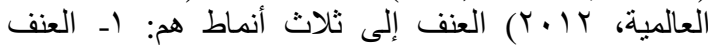

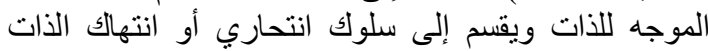

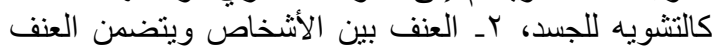

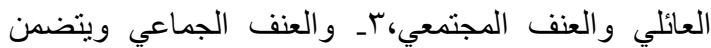

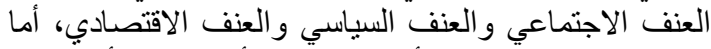

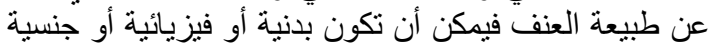

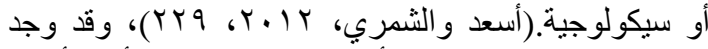

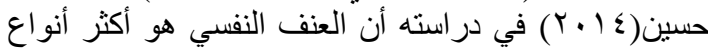

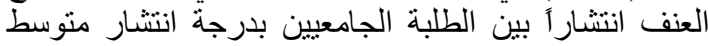

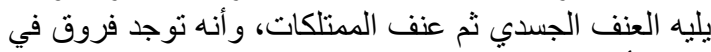

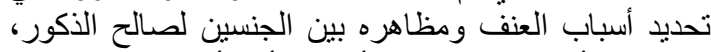

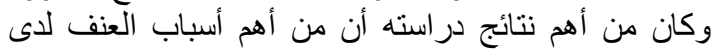

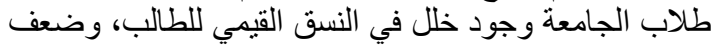

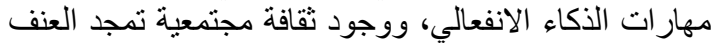
وتعززه، ووجود فراغ سياسي وفكري لأفي ولدى الطلبة.

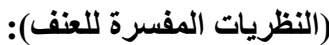
: من وجهة نظر علماء البيوة البيولوجي والفسيولوجي: يربطون بين العنف وعو امل فسيولوجية ور واثية بالدية والدرجية

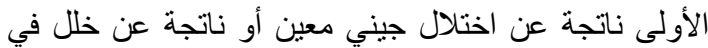

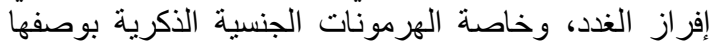

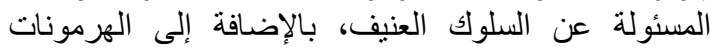

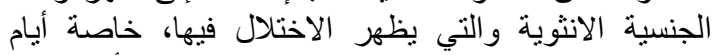
الدورة الثهرية والتي ينتج عنها مظاهر سلوكية أكثر عنفاً

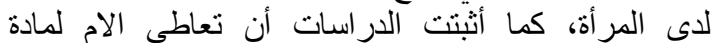

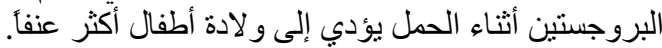

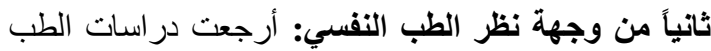

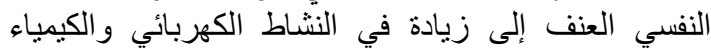

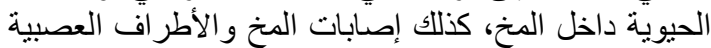

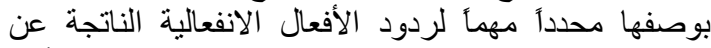

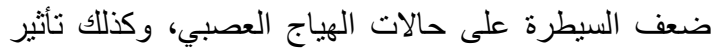

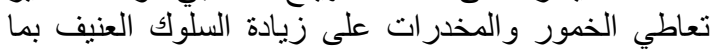

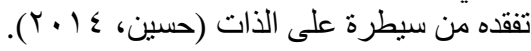

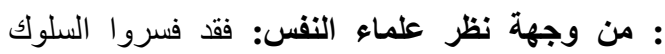

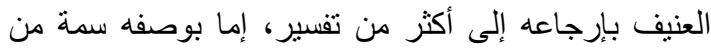

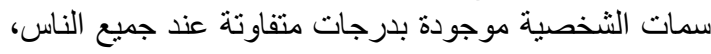

Violence : :

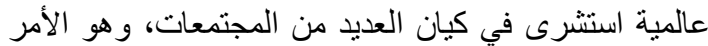

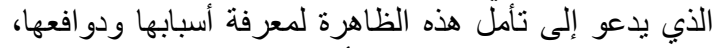

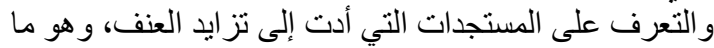

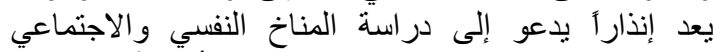

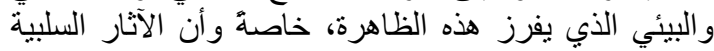

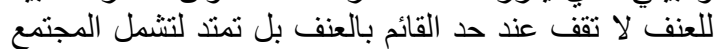

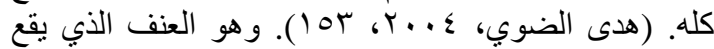

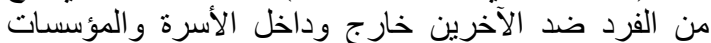

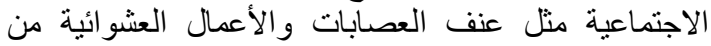

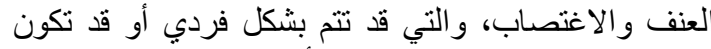

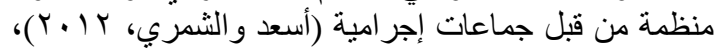

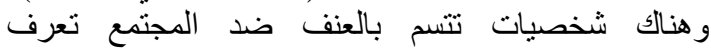

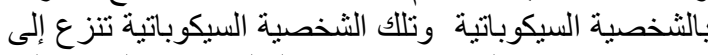

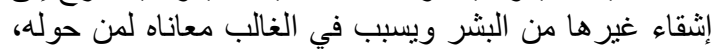

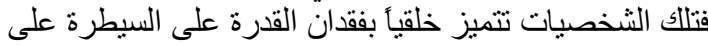

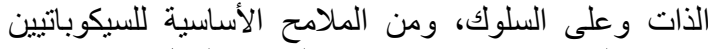

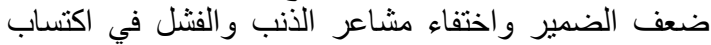

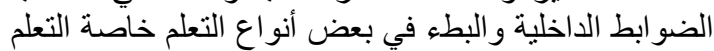

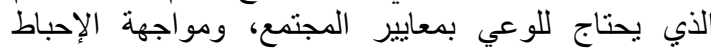

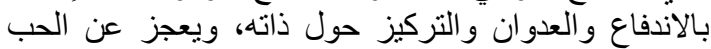

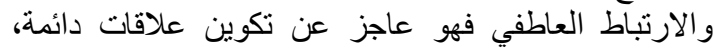

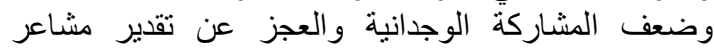

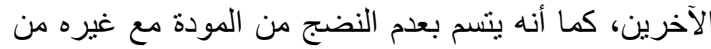

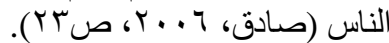

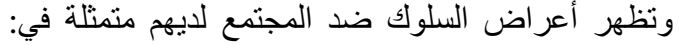

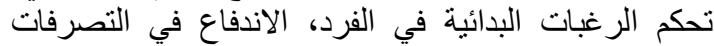

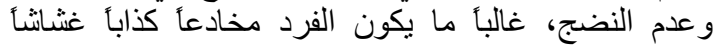

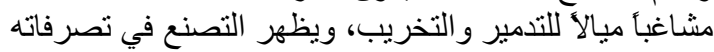
مع نوبات من الغضب، لديه سلوكيات منحرفة كالسرقة لأنة

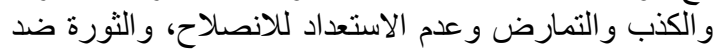

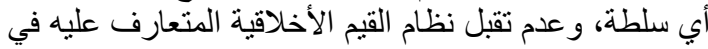

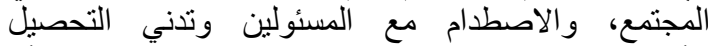

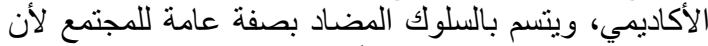

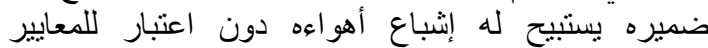

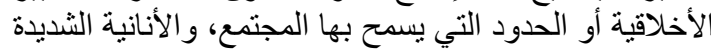

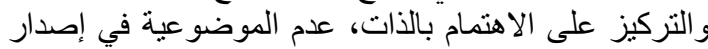

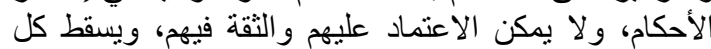

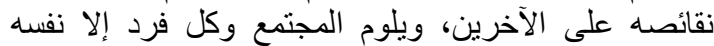

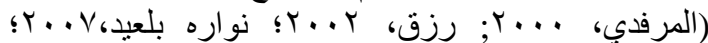

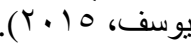

تعريفات العنف: نمط من أنماط السلوك الذي ينتج عن حالة

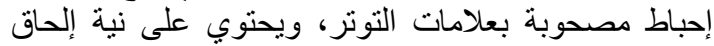

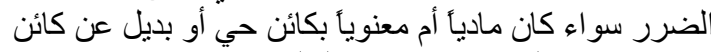

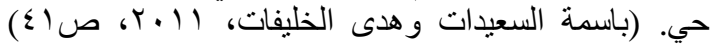

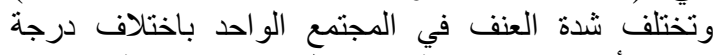

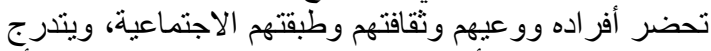

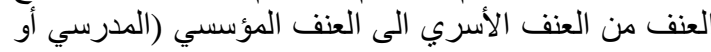

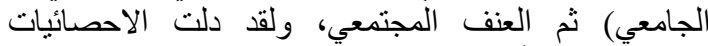

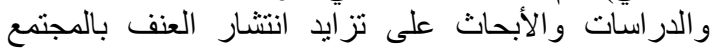


والمدرسة و المجتمع المحلي وجماعة الرفاق، و والبيئة

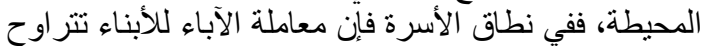

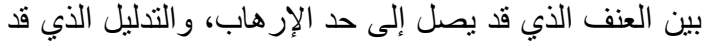

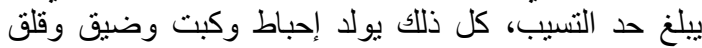

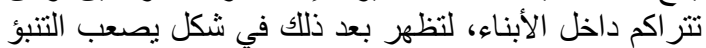

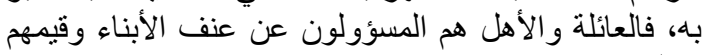

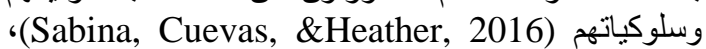
فأفر اد المجتمع وخاصة المراهئ اهقين ينأثرون بثلاث مركبات

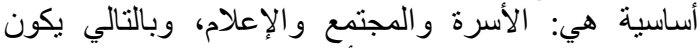

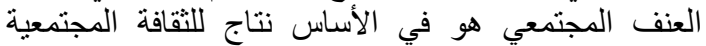

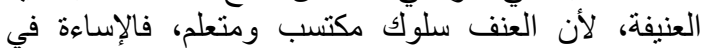

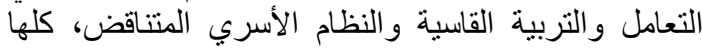

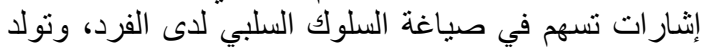

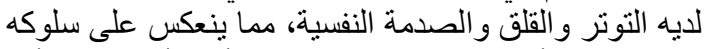
وتكون من الأسباب الكامنة للعنف، كما أن الأثخاص الألئ الأقل

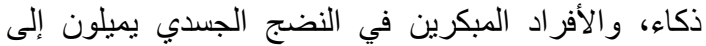

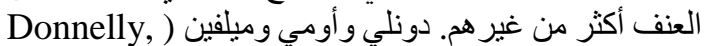

(Oehme\& Melvin, 2016 كما يعد انتشار التسيب والتحلل من الأخلاق والقيم،

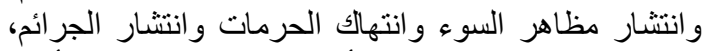
سبباً رئيسيأ في دفع بعض الأفر اد إلى إصلاح هذات التهار الأمور

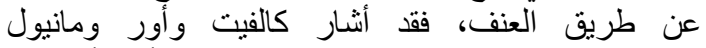
(Calvete, Orue,\&Manuel, 2015) (إلى أن الأبناء في الأسر التي يتناول فيها أحد الوالدين المخدرات ويصدر عنه الأنه

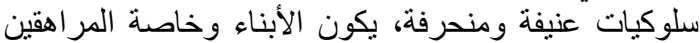

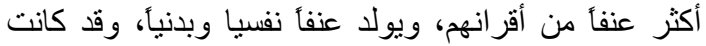

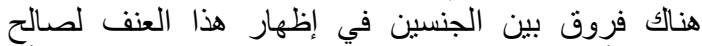

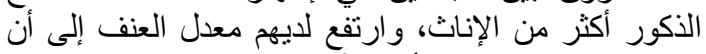
وصل إلى الاعتداء على أحد الآباء.

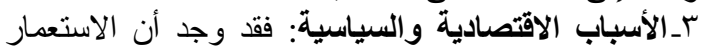

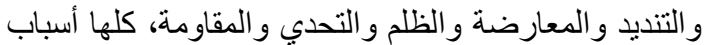

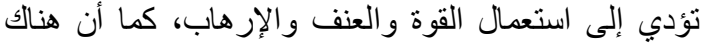

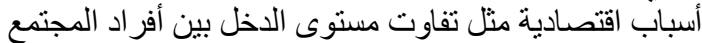

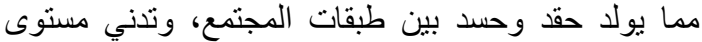

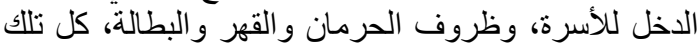

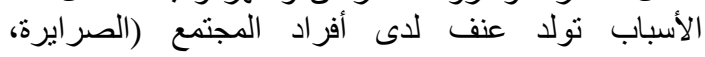

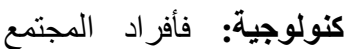

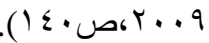

وخاصة المراهقين يتأثرون بوسائل الإعلام، ويثبر الثنامي الثيع

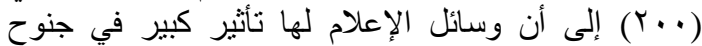

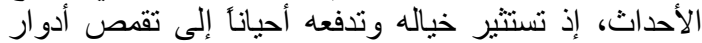

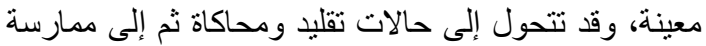

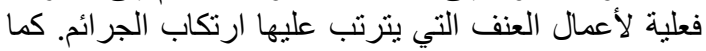

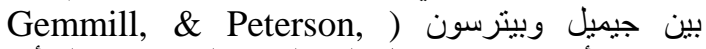
2006). أن استخدام وسائل التكنولوجيا الحديثة كان له أثنر

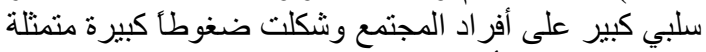

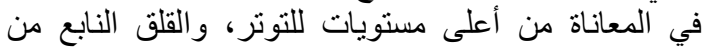

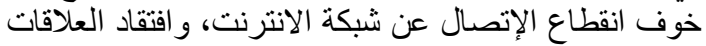

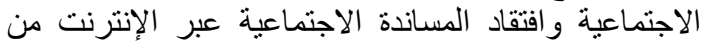

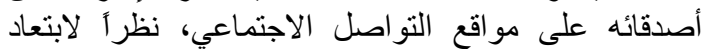

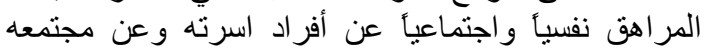

إلى تفسير فرويد للعدوان بوصفه يرتبط بغريزتي الموت

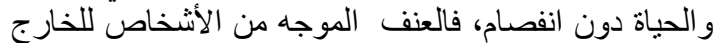

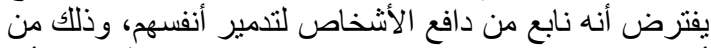

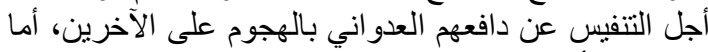

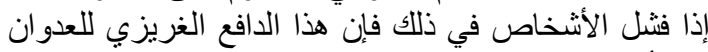

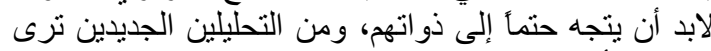

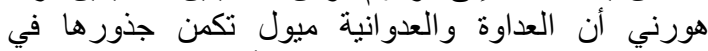

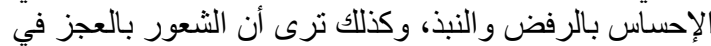

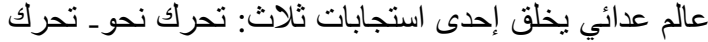

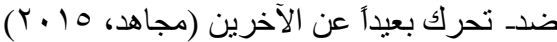

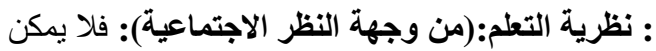

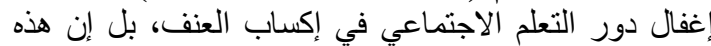

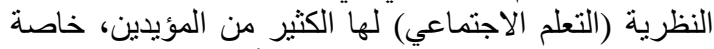

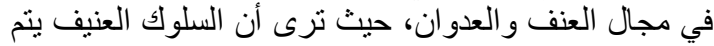

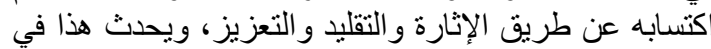

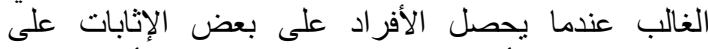

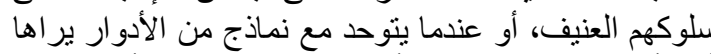

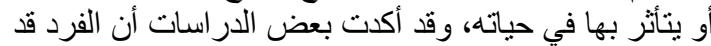

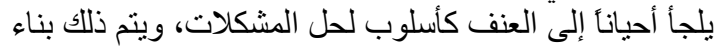

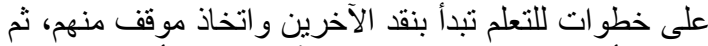
تطوير أساليب التصنيف لإبعاد الآخرين، ثم أخيراً محاولة الإنة

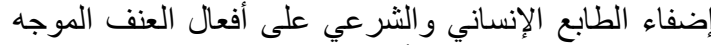

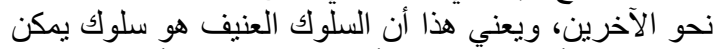

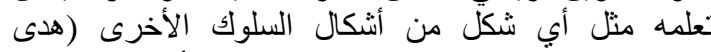

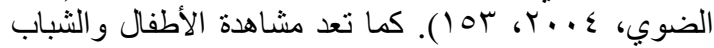

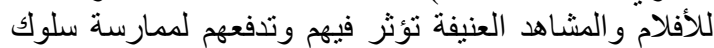

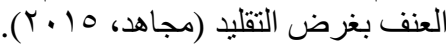

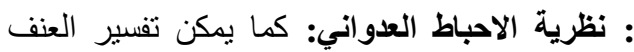

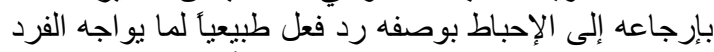

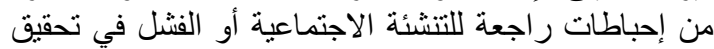

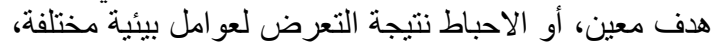

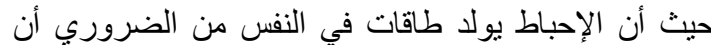
تخفف أو تتصرف بأسلوب مالدا، حتى يشعر الفرد بالراحة

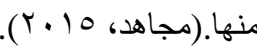

الأسباب المؤدية إلى ممارسة العنف:

العوامل النفسية: وهي مبنية على الغر ائز،

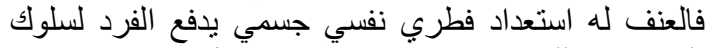

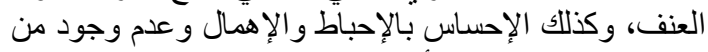

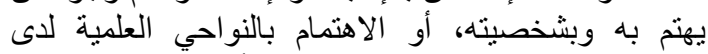

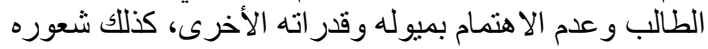

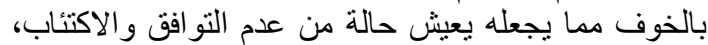

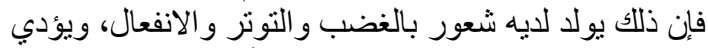

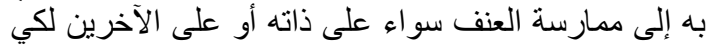

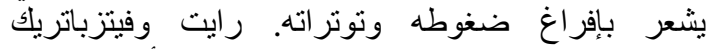

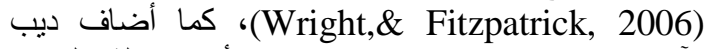
وآخرون (Deb, et. al., 2016). أن مشكلة التكيف العاطفي وانخفاض مفهوم الذات والقلق من أهم مسبيات أنسات العنف لَّى المر اهقين.

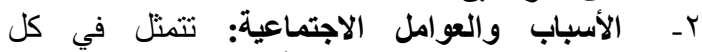
الظروف المحيطة بالفرد من الأسرة والمحيط السكني فئي 
كما قام سلون ومايير (Slone, \& Mayer, 2015). بدراسة عن الفروق بين الجنسين في مظاهر العنف وآثاره

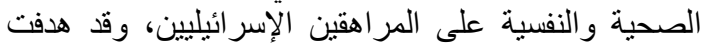

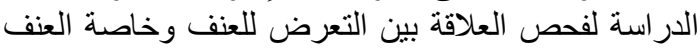

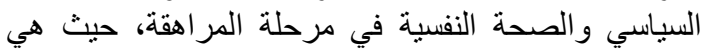

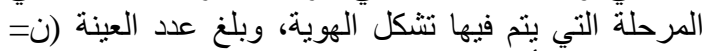

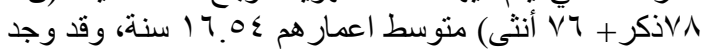

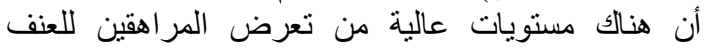

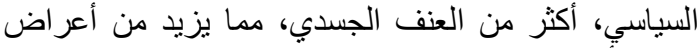

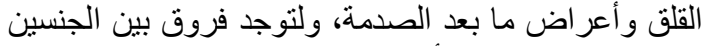

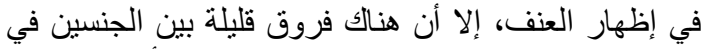
الثعور بالقلق لصالح الإنان، بينما كان الذكور أكثر مخاطرة

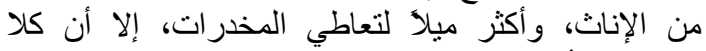

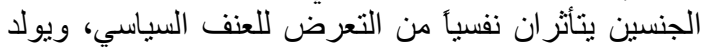

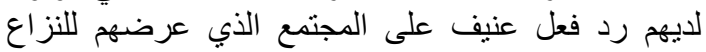

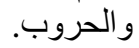

: أنشار بينتا وكلادوت وترينت

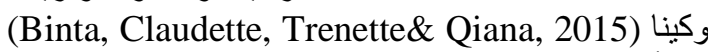
إلى أنه يقع عبء كبير ودور قوي على الآباء لتخفيض سلوك

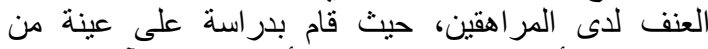

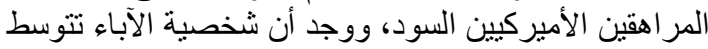

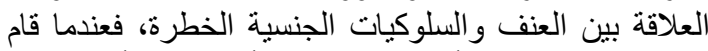

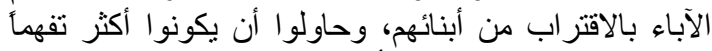

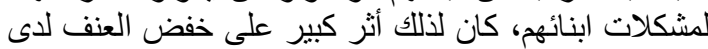

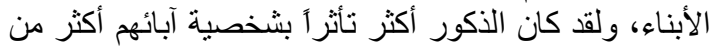

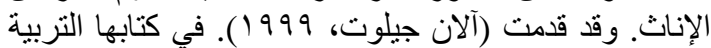

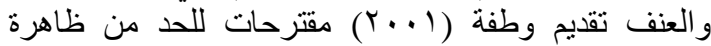
العنف أهمها: العمل على زيادة الوعي الديني والأخلافي- لإلى

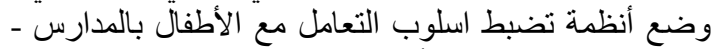
محاربة ظاهرة عمالة الأطفال- تعزيز الدور الإعلامي لبث الإلث

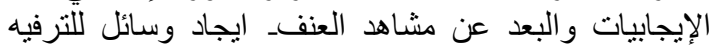

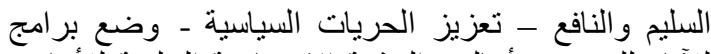

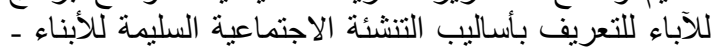

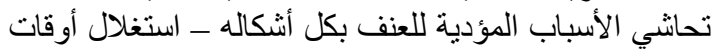

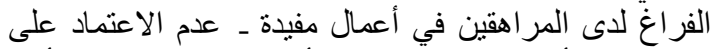

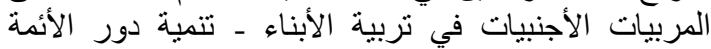
و الخطباء في ترسيخ المبادئ و القيم الإسلامية ــ العمل على الإنى القضاء على البطالة والفقر وتحقيق مبدأ الدساواة بين أفراد العيد

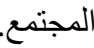

مما سبق وفي ضوء نتائج الاراسات السابقة يمكن صياغة

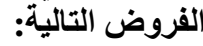

1- يوجد مسنتوى منوسط للضنغوط البيئية المختلفة (فيزيقيةــ اجتماعية_ تكنولوجية) لدى المراهية الهقين

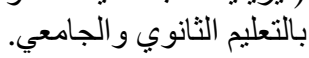

r- بوجد مستوى جيد من الانتماء (الوطني- القومي

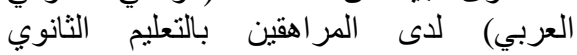

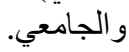

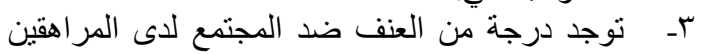

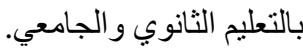

فيصبح وحيداً في وسط اسرته ومعارفه إذا ما انفصل عن

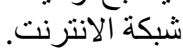

كما أثار (حطب، التُب، 1991). أن العنف المتفجر في أرجاء العالم هو أحد أثنكال نشر العولمة وتعميمها، فالعولمّة تعني العني

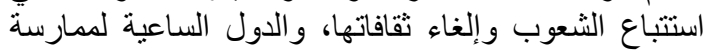

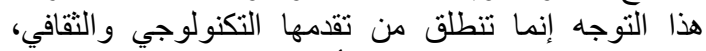
وتستغل مزاياها لممارسة كل أنثكال السبطرة الإيديولوجية التئية

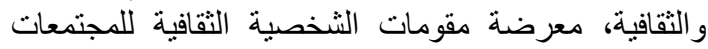

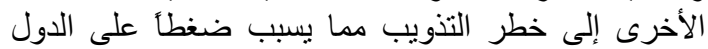
الضعيفة، ويعد الإعلام وسيلة تحقيق هذه الهيمينة، وتضطر التيطر

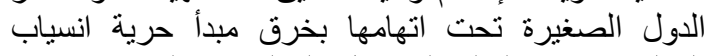

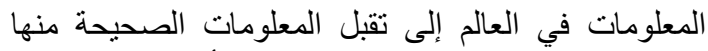

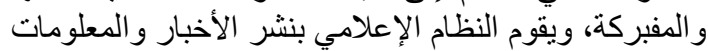

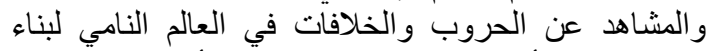

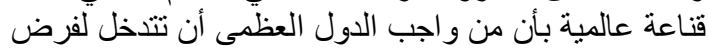
السلام ووقف الدجازر وتعميم حقوق الإنسان، وفي ظلت لتل فرض الذاتيات الثقافية ينقلب الدور إلى تخريب الإنسان وعي الأمم و الثعوب ووضع اليد على الثؤون الداخلية للأدول الصغيرة

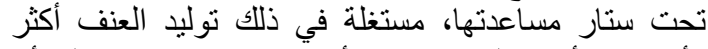

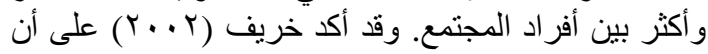

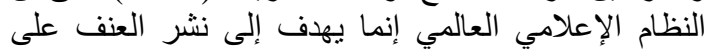

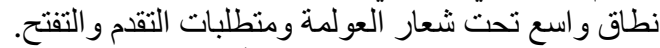

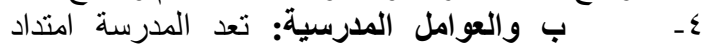

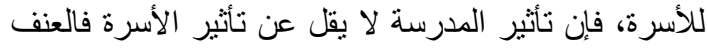

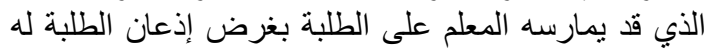
هو إذعان ظاهري مؤقت، لا يلبث أن يتحول إلى كراهية الذانية ورفض وعنف ضد المجتمع، كذللك العلاقة بالأقران،

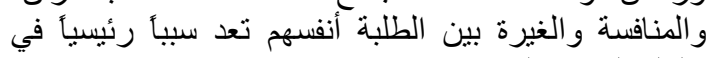

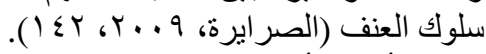

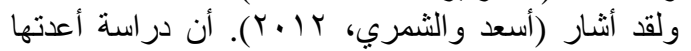

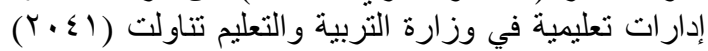

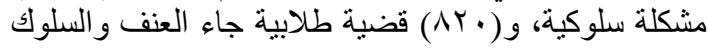

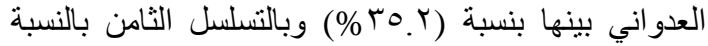
للمشكلات، مما يدل على انتشارها وخاصة في في المرحلة المتوسطة و الثانوية.

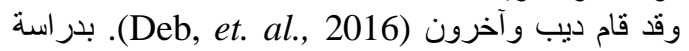

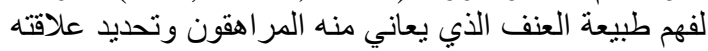

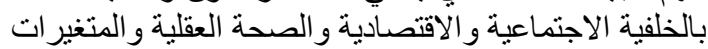

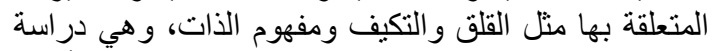

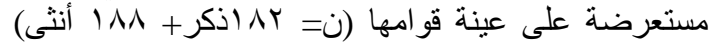
من ست مدارس ثانوية في كلكتا، وباستخدام مقاييس نفسية

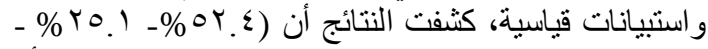

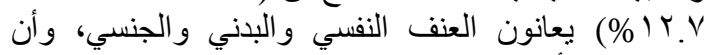

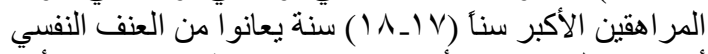

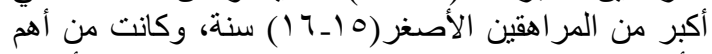

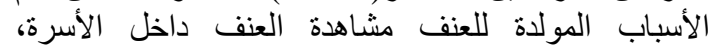
وتوصلوا إلى أن للعنف آثار سلبية على الثلى الصحة النفسية

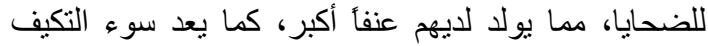

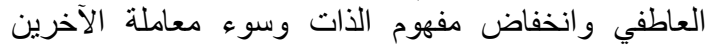
للمر اهق من أهم الأسباب المؤدية للعنف بين المر اهقين. 


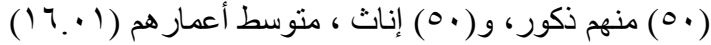

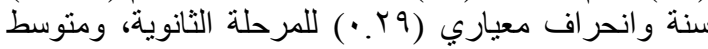

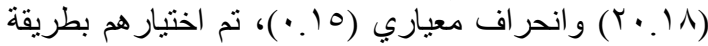

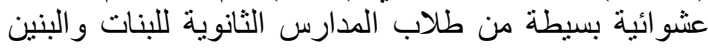
بمنطقة محايل التعليمية وكليات العلوم والآداب التابل والمجتمع

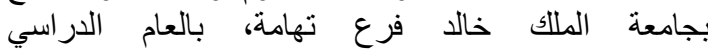

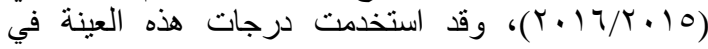
التحقق من فروض الدراسة الحالية.

مقياس الضغوط البيئية (فيزيقيةـ اجتماعيةـ تكنولوجية) :

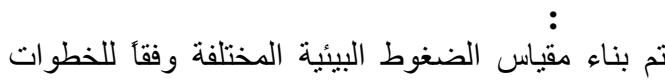

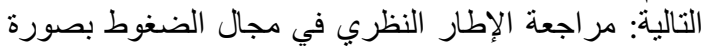

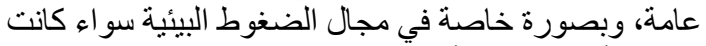

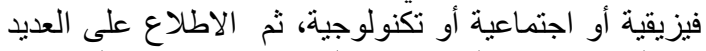

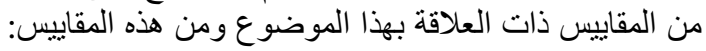

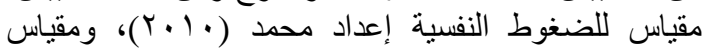

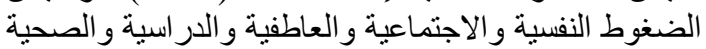

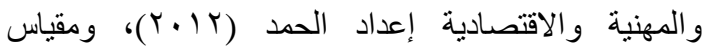

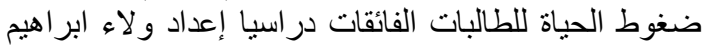

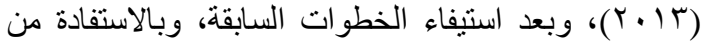

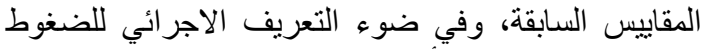

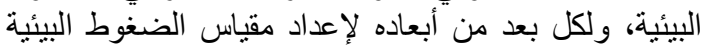

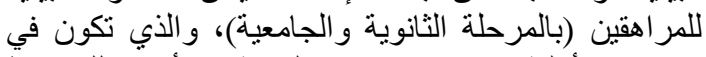

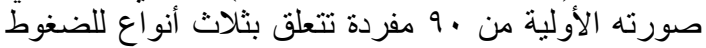

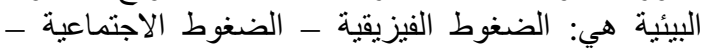
الضغوط ألتكنولوجية. تصحيح المقياس: يتكون المقياس في صورته الأولية من

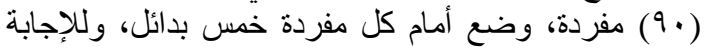

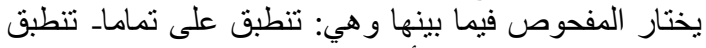

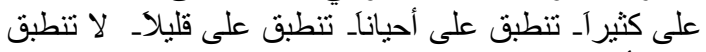

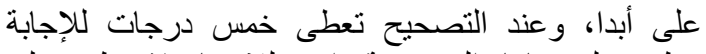

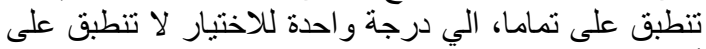
أبدا تناز لياً.

وقد تم حساب ثبات وصدق المقياس بعدة طرق كما يلي:

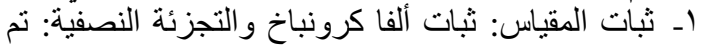

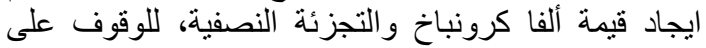

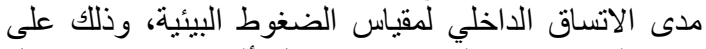

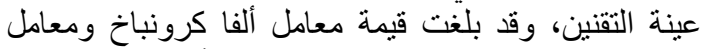
التجزئة النصفية لجتمان للمقياس ككل وللأبعاد الفرعية كما هو موضح بالجدول النالي:
ع- توجد علاقة ارتباطية دالة احصائياً بين درجات الطلاب المراهقين في الضغنوط البئية الئية المختلفة

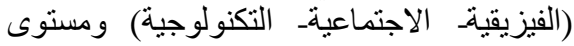
الانتماء الوطني و القومي العربي.

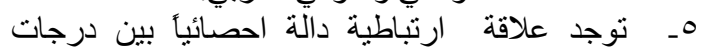
الطلاب المراهقين في الضغوط البئية البيئية المختلفة

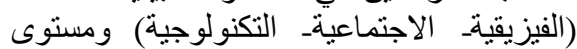
العنف ضد المجتمع لديهم. 7- توجد فروق دالة احصائية بين منوسطات درجات

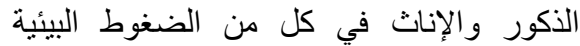
و العنف ضد المجتمع و الانتماء الوطني والقوني

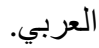
V- توجد فروق دالة احصائياً بين متوسطات درجات

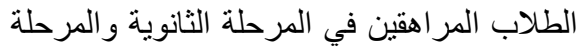

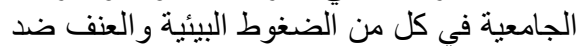
المجتمع و الآنتماء الوطني و القومي العربي.

منهجية البحث واجراءاتهه: : منهج البحث:

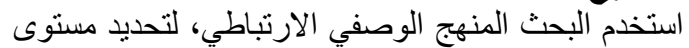

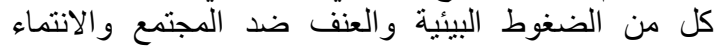

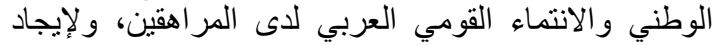

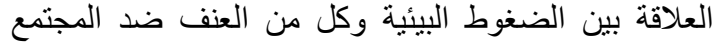

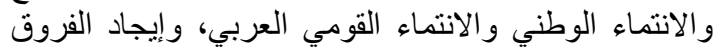

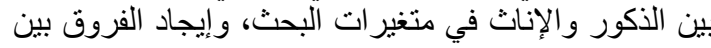

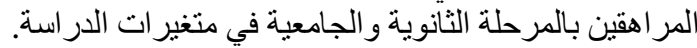

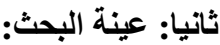

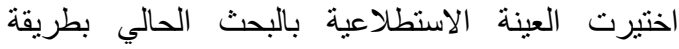

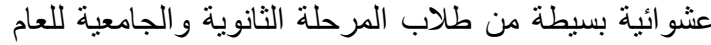

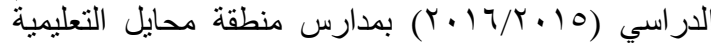

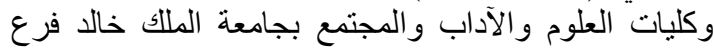

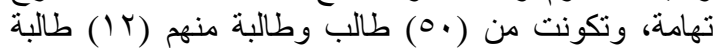

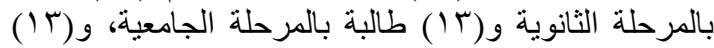

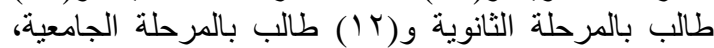

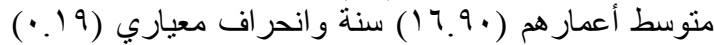

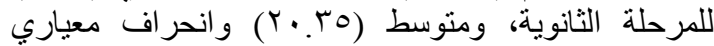

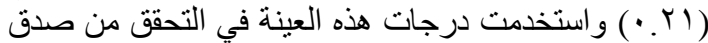

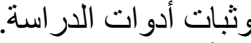

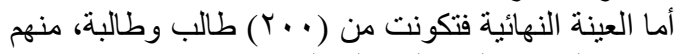

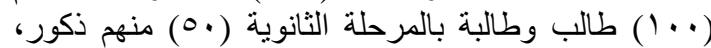
و(•) إناث، و( •. (1) طالب وطالبة بالمرحلة الجامعية

\begin{tabular}{|c|c|c|c|c|c|}
\hline النصفية & & & النصفية & & \\
\hline$\cdot V Y$ &..$V \mu$ & الضغوط التكنولوجية &. .79 & $\cdot V V$ & الضغوط الفيزيقية \\
\hline. $\mathrm{VT}$ & $.1 \mathrm{VO}$ & الارجة الكلية للمقياس &..$\vee 1$ & .199 & الضغوط الاجتماعية \\
\hline
\end{tabular}

معامل الارتباط بين مرتي التطبيق، والذي يعبر عن معامل

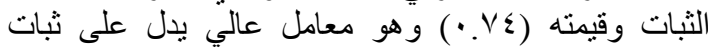

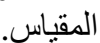

الثبات بطريقة إعادة التطبيق: تم حساب ثبات المقياس بطريقة

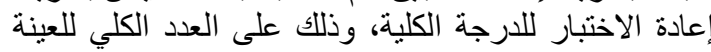

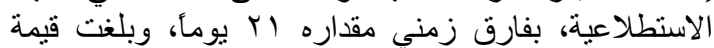


r- تصحيح المقياس: يتكون المقياس في صورته النهائية من

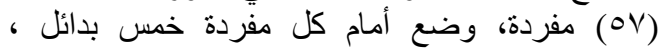

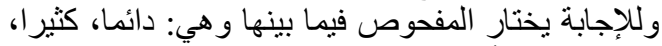

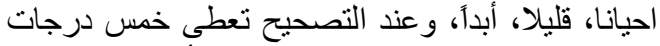
للإجابة دائما، الي درجة والبال واحدة للاختيار أبداً.

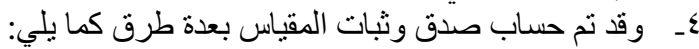

$$
\text { ○ـ ـ ثبات المقياس: }
$$

(أ) نم إيجاد ثبات ألفا كرونباخ والتجزئة النصفية للوقوف التئن

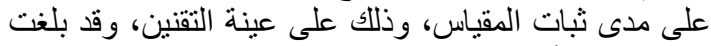
قيمة معامل ألفا كرونباخ ومعامل التجزئة النئة النصفية لجنمان اللمقياس ككل وللأبعاد الفرعية كما هو موضح بلفئل بالجدول التالي:

\begin{tabular}{|c|c|c|}
\hline النصفية & & \\
\hline$\cdot . \wedge r$ &.$\wedge \wedge$ & \\
\hline. .19 & $\cdot . \wedge 1$ & \\
\hline .10 & $\cdot . \wedge T$ & الدرجة الكلية للمقياس \\
\hline
\end{tabular}

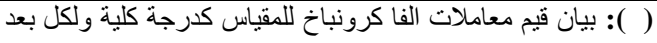
من أبعاد المقياس.

(ب)الثبات بطريقة إعادة التطبيق: تم حساب ثبات المقياس بطريقة إعادة الاختبار للارجة الكلية، وذللك على إدئ العدد الكلي

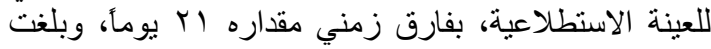

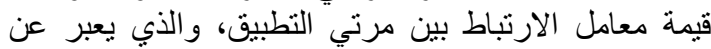

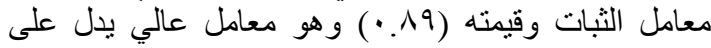
ثبات المقياس.

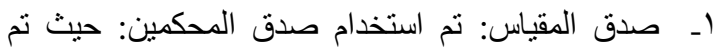

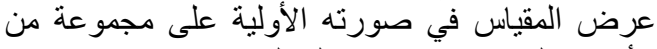

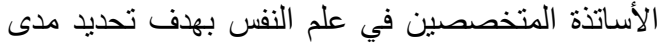

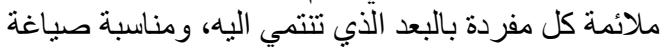

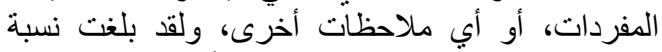

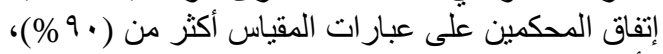

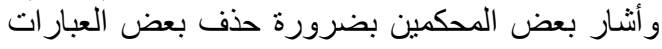

وتعديل صياغة بعضها لكي تلاءم البيئة السعودية.

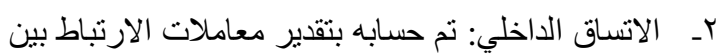

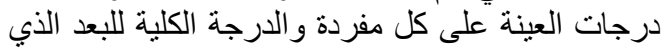

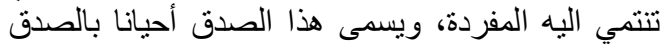

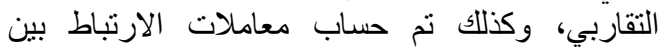

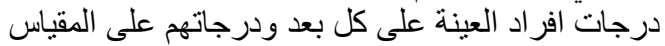

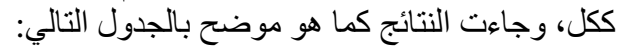

\begin{tabular}{|c|c|}
\hline - & العنف النفسي \\
\hline • & العنف المادي \\
\hline
\end{tabular}

( ) ( ): معاملات ارتباط درجة كل بعد والدرجة الكلية لمقياس الضغوط البيئية.

يتضح من الجدول السابق إن جميع قيم معاملات الارتباط

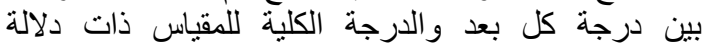

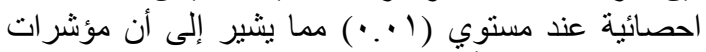

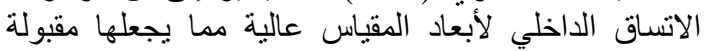

r- صدق المقياس: تم استخدام طريقة صدق المحكمين: حيث تم عرض المقياس في صورته الاولية على مجموعة

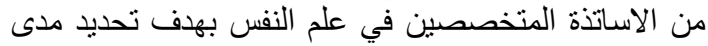

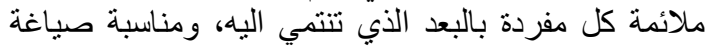

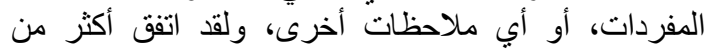

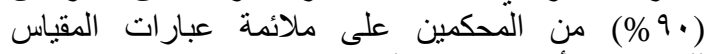

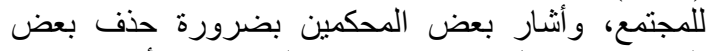
العبارات وتعديل صياغة بعضراغ بعضا لكي تكون أكثر مناسبة للمجنمع السعودي.

r- الاتساق الداخلي: تم حسابه بتقدير معاملات الارتباط بين

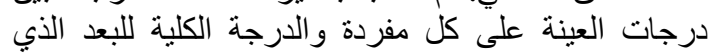

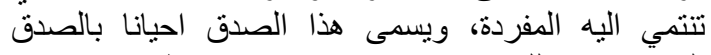

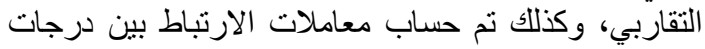

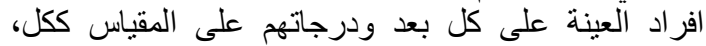
وجاءت النتائج كما هو موضح لول بالجدول التالي:

\begin{tabular}{|c|c|}
\hline.$\vee V I$ & الضغوط الفيزيقية \\
\hline .70 & الضغوط الاجتماعية \\
\hline$\because V Y$ & الضغوط التكنولوجية \\
\hline
\end{tabular}

( ) ( ): معاملات ارتباط درجة كل بعد والدرجة الكلية لكقياس الضغوط البيئية.

يتضح من الجدول السابق إن جميع قيم معاملات الارتباط

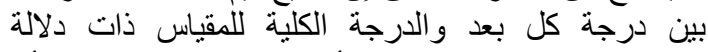

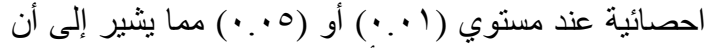

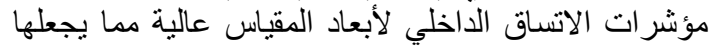

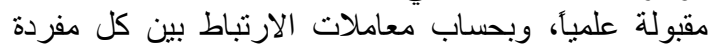

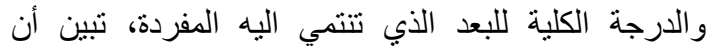

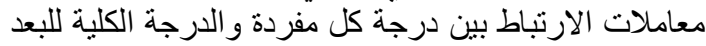

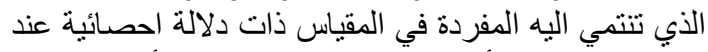

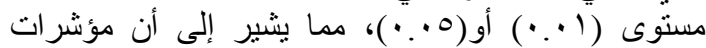

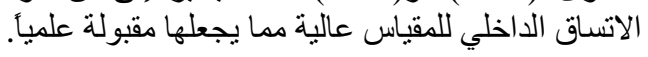
ا- ـ مقياس العنف ضد المجتمع و أفر اده : إعداد الباحثة.

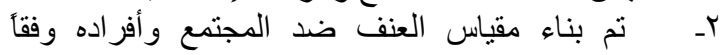
للخطوات النالية: مراجعة الإطار النظري في في مجال

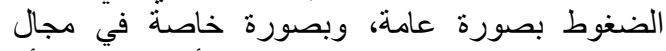

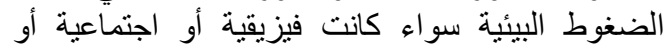

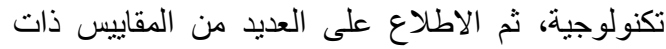

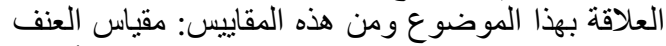

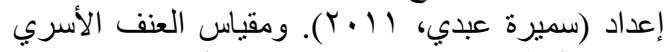

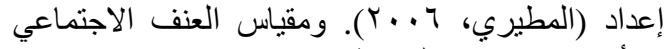

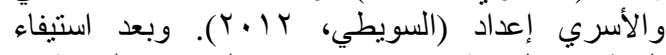

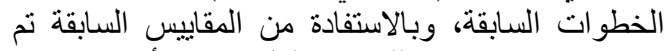

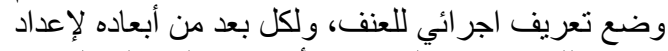

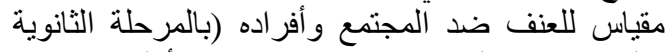

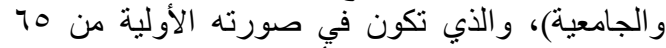

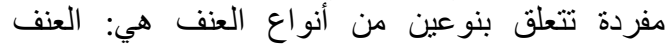

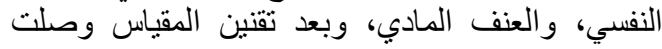

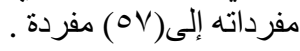




\section{قتشة النتائج وتفسيرها:}

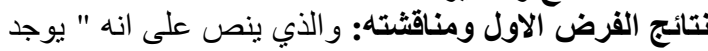

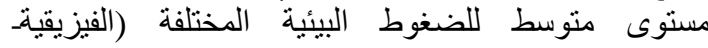

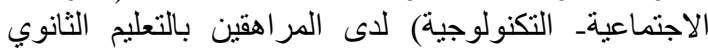

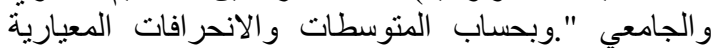

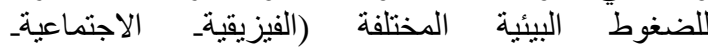
التكنولوجية)، تم الحصول على البيانات التالية الموضحة

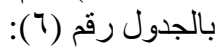

\begin{tabular}{|c|c|c|}
\hline 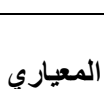 & & الضغوط البيئية \\
\hline$r 1.01$ & 10.YN & الضغوط الفيزيقية \\
\hline$r \cdot . \leqslant 0$ & $V 7.0$ & الضغوط الاجتماعية \\
\hline$r \cdot . T \Lambda$ & $\mathrm{VQ.rT}$ & الضغوط التكنولوجية \\
\hline $0 r . \wedge 9$ & $T \varepsilon \cdot . T V$ & الارجة الكلية للضغوط \\
\hline
\end{tabular}

( ) (لبيان متوسطات الضغوط البيئية.

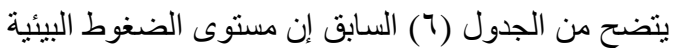

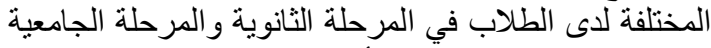

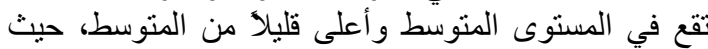
كانت متوسطات العينة في الضغوط الضئر الفيزيقية والضغوط

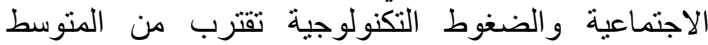
الحسابي لكل نوع من هذه الأنواع من الضغوطية الضغوط (المتوسط

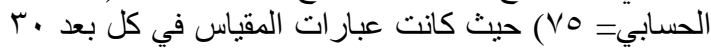

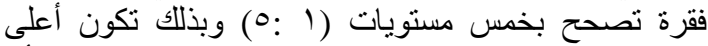

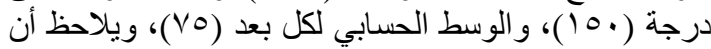

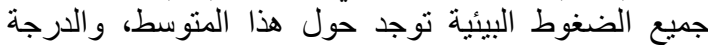

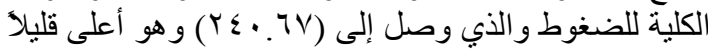

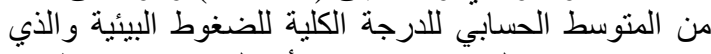

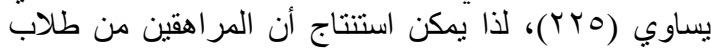

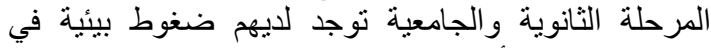

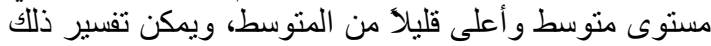

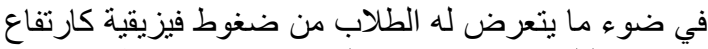

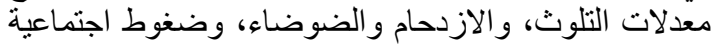

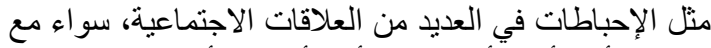

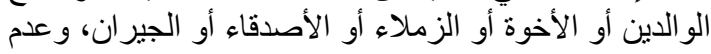

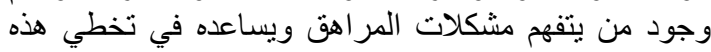

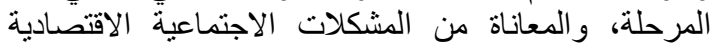

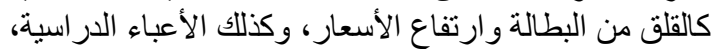

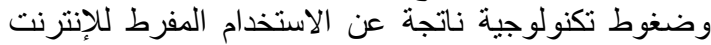

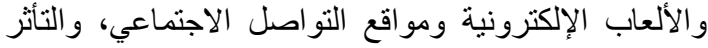

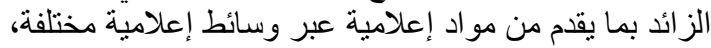

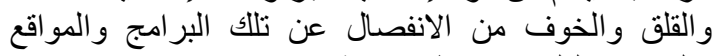
و الخوف و القلق من انقطاع شبكة الإنترنت.

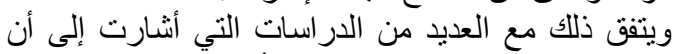

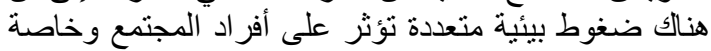

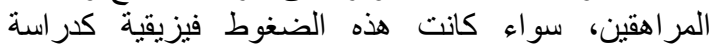

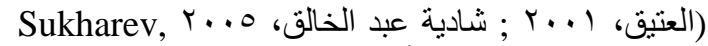
( \& Zschech, 2011;

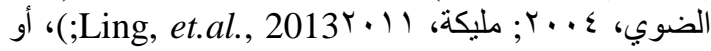

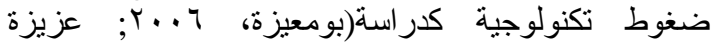

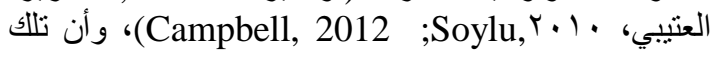

علمياً، وبحساب معاملات الارتباط بين كل مفردة والدرجة الكلية للبعد الذي تنتمي إليه المفردة، تبين أن الن معاملات

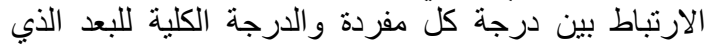

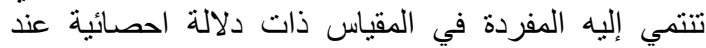

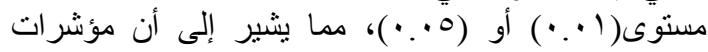
الاتساق الداخلي للمقياس عالية مما يجعلها مقبولة علمياً. و و مقياس الانتماء الوطني والقومي العربي للمراهقين

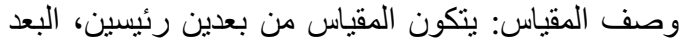

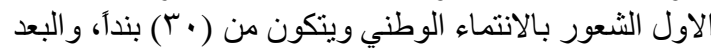

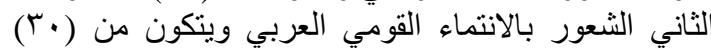

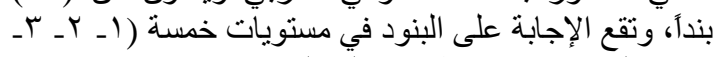
ع ـ 0) لتحديد درجة انطباقها على الثخص.

ثبات وصدق المقياس: قامت معدة المقياس بحساب ثبات بلثات

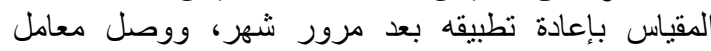

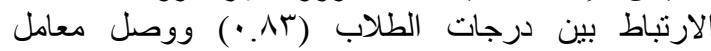

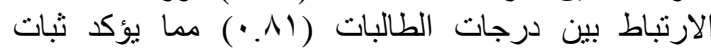

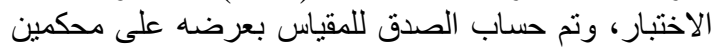
من الأساتذة الدتخصصين في الصحة النفسية، وتم تعديل

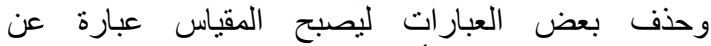

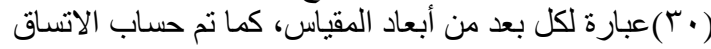

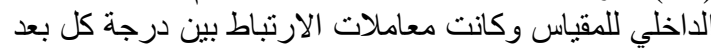

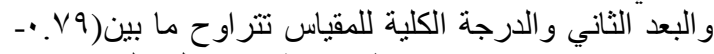

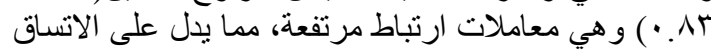

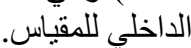
تقتين المقياس في الدراسة الحالية: قامت الباحثة بتعديل

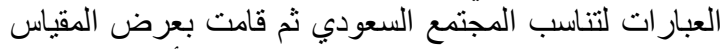

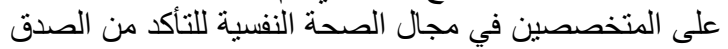

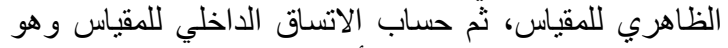

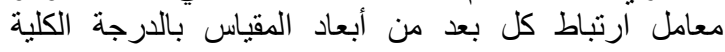

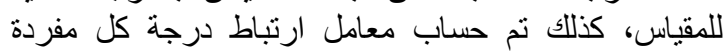

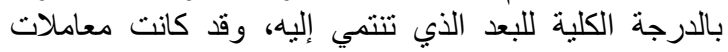

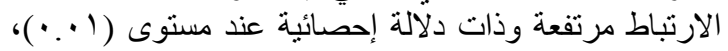

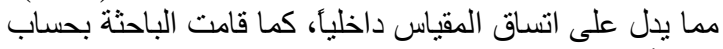
ثبات ألفا كرونباخ و التجزئة النصفية، كما بالجدول التالي:

\begin{tabular}{|c|c|c|}
\hline النصفية & & \\
\hline .79 & $\cdot V 1$ & \\
\hline$\because V Y$ & $\because V V$ & \\
\hline$\cdot V \cdot$ &.$V T$ & الدرجة الكلية للمقياس \\
\hline
\end{tabular}

( ) ( ) بيان قيم معاملات الفا كرونباخ للمقياس كدرجة كلية ولكل بعد من أبعاد المقياس. و هي معاملات عالية، مما يدل على ثبات المقياس.

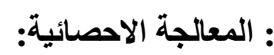

استخدمت الباحثة الأساليب الإحصائية التالية بواسطة

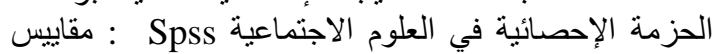

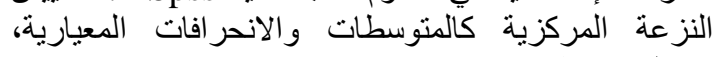
معامل ارتباط بيرسون، اختبار "ت اتل 
المحافظة على الهوية الثخصية حتى لا تضيع في ازدحام

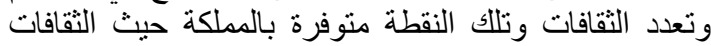
المتعددة في جميع المجالات، وهذا يتفق مع درة دراسة جلاس

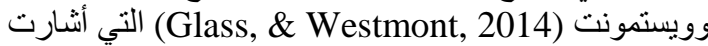
في نتائجها إلى أن التفاعل بين الثقافات لله أثر كبير على التى

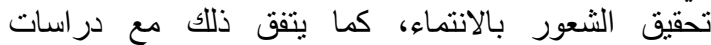

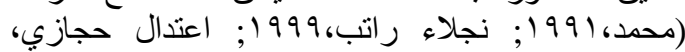

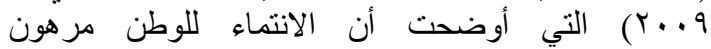

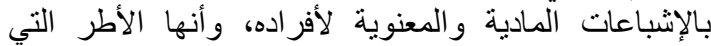

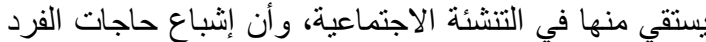

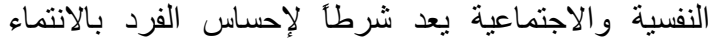

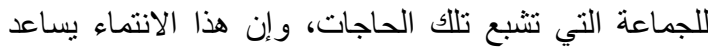

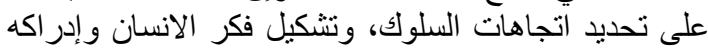

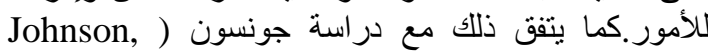
2009) التي أوضحت العلاقة بين الانتماء ودرعم المعلمين

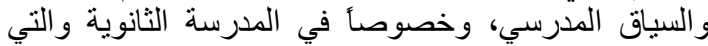

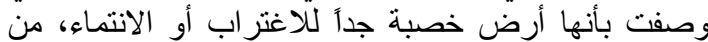

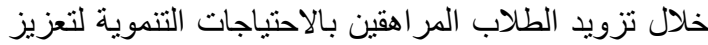
الشعور بالانتماء لديهم.

نتائج الفرض الثالث ومناقشتها: و الذي ينص على الأه " توجد

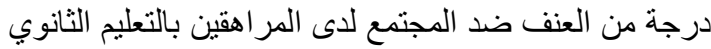

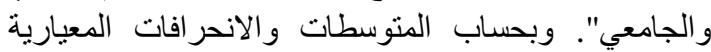
للعنف ضد المجتمع (النفسي والجسدي)، تم الحصول على

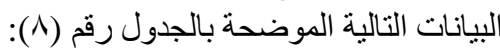

\begin{tabular}{|c|c|c|}
\hline المعياري & & \\
\hline $9 . \wedge 1$ & $01.7 \mathrm{~V}$ & \\
\hline $1 . \mathrm{r \mu}$ & $r \leq Y Y$ & \\
\hline $10 . \leqslant V$ & 10.19 & الكلية للعنف \\
\hline
\end{tabular}

بتضح من الجدول السابق رقم (^) إن ن مستوى العنف النف

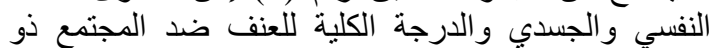
مستوى منخفض لدى الطلاب في المرحلة الثانوية والمرحلة

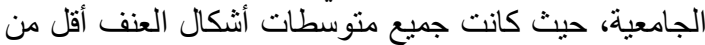

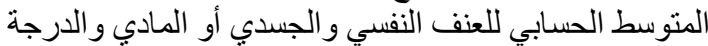

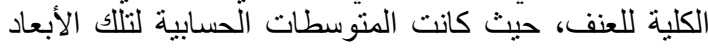

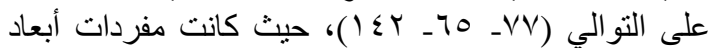

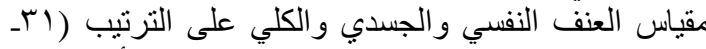

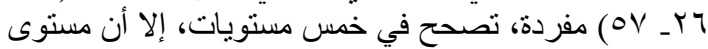

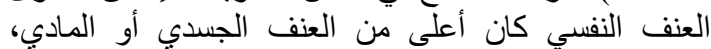
ويمكن استتناج أن المراهين الفين من طلاب المرحلة الثانوية

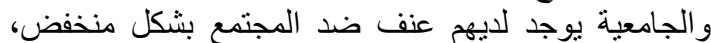

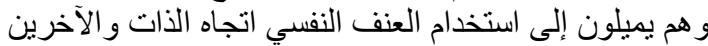

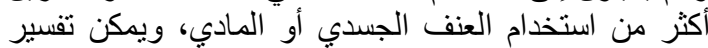

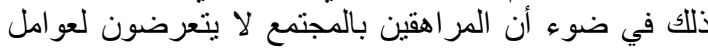

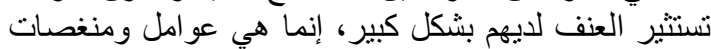

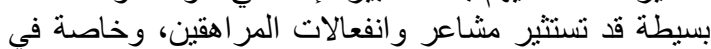

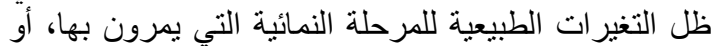

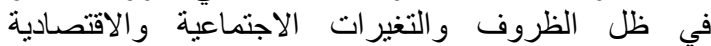

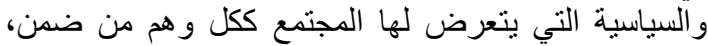

الضغوط لها تأثثر كبير في استجاباتهم الفسيولوجية للضغط،

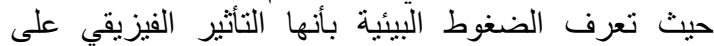

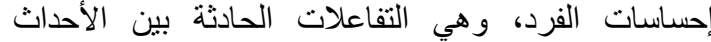

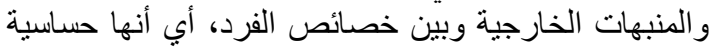

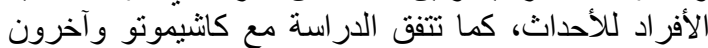
(Kashimoto, et.al., 2016).

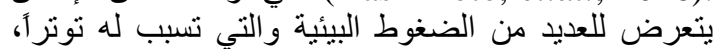
وتؤثر على جميع أعضاء جسده، كما أن ضبط الإني الذات المتكرر يؤثر سلباً على الإنسان.

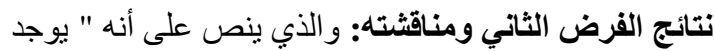

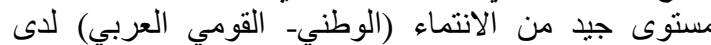

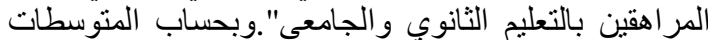

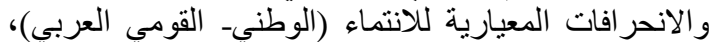

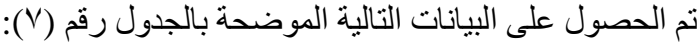

\begin{tabular}{|c|c|c|}
\hline المعياري & & \\
\hline 17.91 & 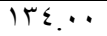 & \\
\hline IV.9Y & $11 \% .07$ & \\
\hline TI.T. & Y70.YY & الارجة الكلية للانتماء \\
\hline
\end{tabular}

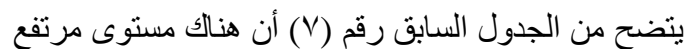

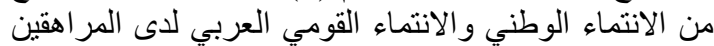

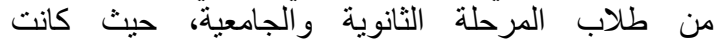

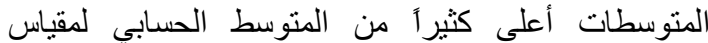

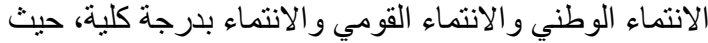

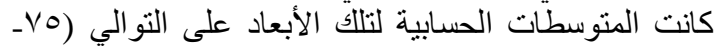

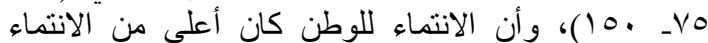

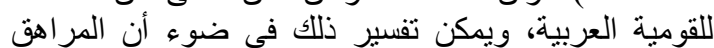

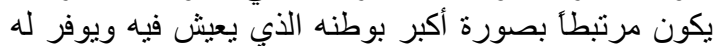

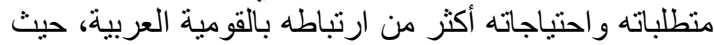

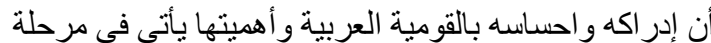

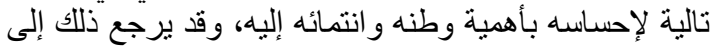

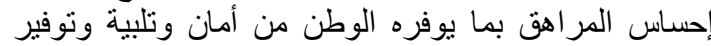

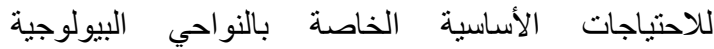

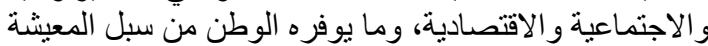

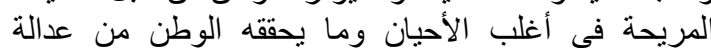

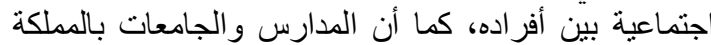

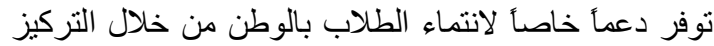

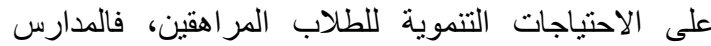
و الجامعات حريصة على تقديم المكافآت المادية والمتينة المعنوية لتحفيز الطلاب على الاجتهاد وتوفر لهم سبل فيل الابتعاث

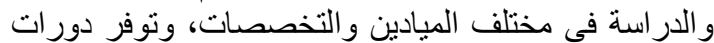

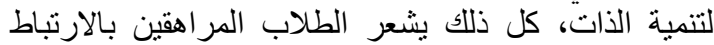

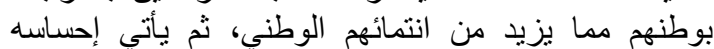

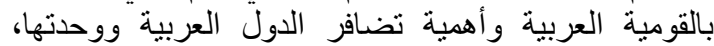

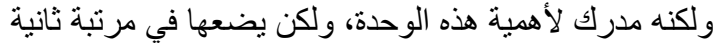

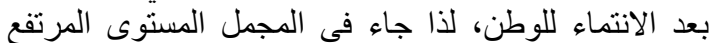

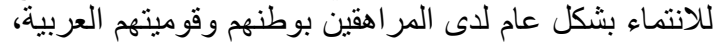

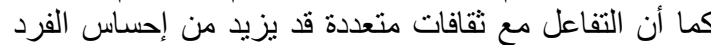

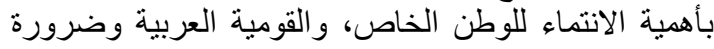


Sabina, et. al., 2016; Donnelly, et. al., ) دراسات 2016) في أن هناك عو امل مجتمعية وأسرية و إعلامية تكون من الأسباب الكامنة للعنف.

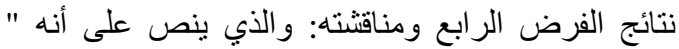

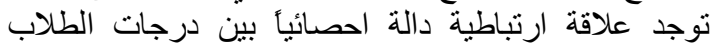

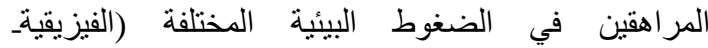
الاجتماعية- التكنولوجية) ومستوى الانتماء الوطني و والانتماء

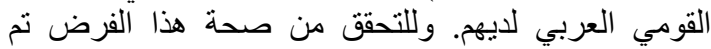

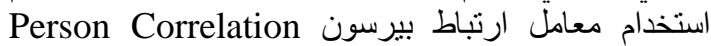
وجاءت النتائج كما يوضحها الجدول رقم (9).
فكان من الطبيعي أن يكون هناك درجة ولو منخفضة من ون

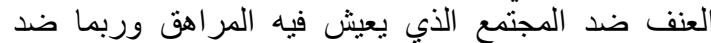

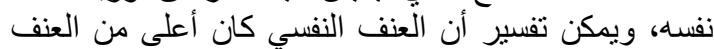

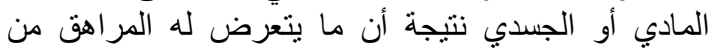

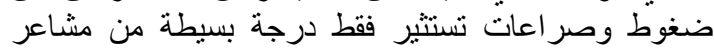

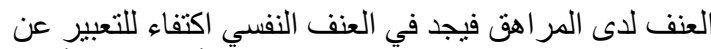

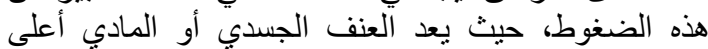

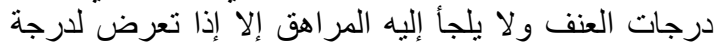

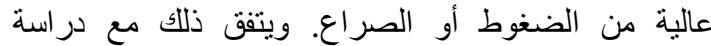

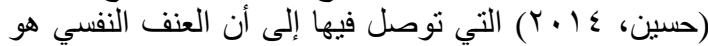
أكثر أنو اع العنف انتشار آ بين الطلبة الجامعيين بدرجة النتشار النتار

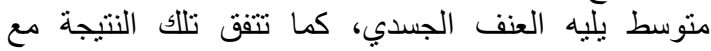

\begin{tabular}{|c|c|c|c|}
\hline \multirow[b]{2}{*}{ الارجة الكلية للانتماء } & & & \multirow[t]{2}{*}{ الضغوط البيئية } \\
\hline & & & \\
\hline$\because 1.9$ & $.1 \mathrm{~V}$. & $\because \cdot r \mid$ & الفيزيقية \\
\hline$\because r \mid r$ & . YKM &. .107 & الضغوط الاجتماعية \\
\hline$* * . . \leqslant 70$ & $* * . \leqslant 09$ & $* . r \vee T$ & الضغوط التكنولوجية \\
\hline$* . \Gamma \leq \Gamma$ & $* . \Gamma V I$ & *. rOY & الارجة الكلية للضغوط البيئية \\
\hline
\end{tabular}

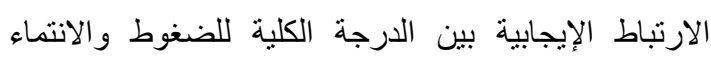

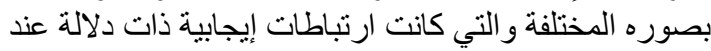

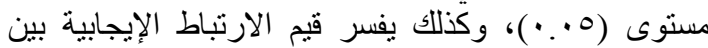

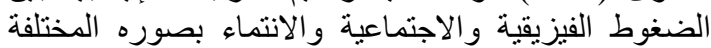

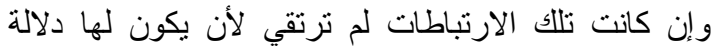

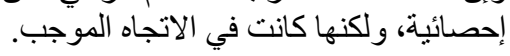

أما الضغوط التكنولوجية فقد كانت ذات التوان ارتباط إيجابي

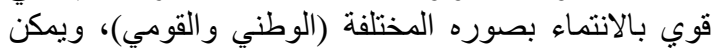

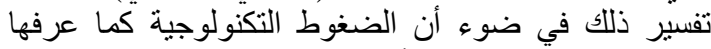

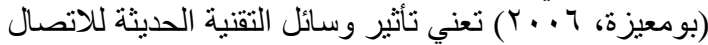

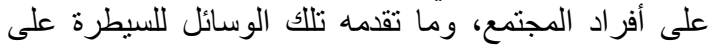

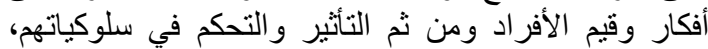

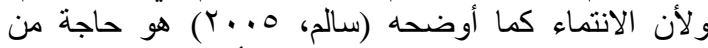
الحاجات النفسية والإنسانية لدى كل أفراد الداد المجتمع، هذه

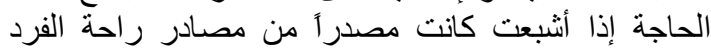

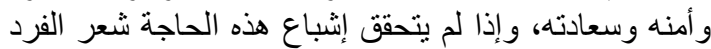

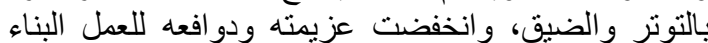

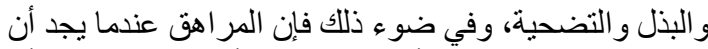

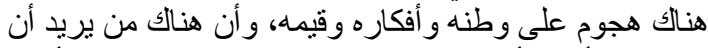

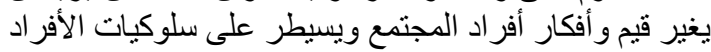

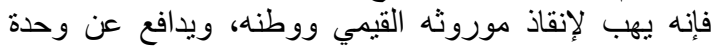

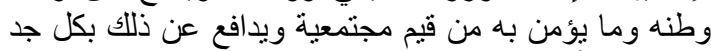

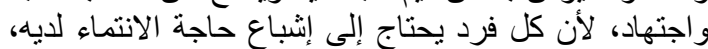

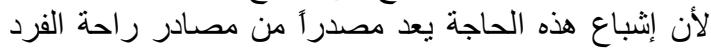
و أمنه وسعادته، وقد وجدت تلثك العلاقة الارتباطية الإيجابية بين مراهقين منطقة عسير على الأخص حيثة الارثي أن التفكير

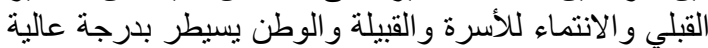

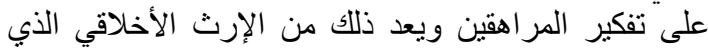
أنشار إليه إدريس (Idriss, 2003) من أن الطلاب يعتمدون

$$
\text { يتضح من الجدول السابق رقم (9) ما يلي: }
$$

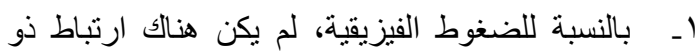

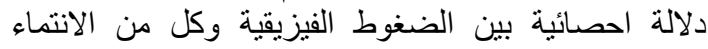
الوطني والانتماء القومي العربي والدرجة الدئية الكلية للانتماء الوطني والقومي، ولكنها ارتباطات إيجايية ولكن غير دالة الكية لكنية احصائيًا.

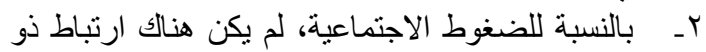

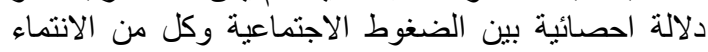
الوطني والانتماء القومي العربي والدرجية الإبة الكلية للانتماء

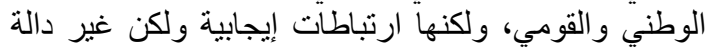

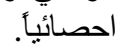

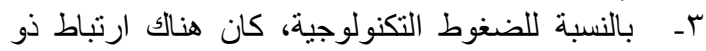

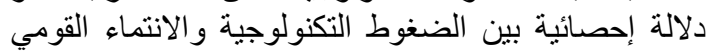

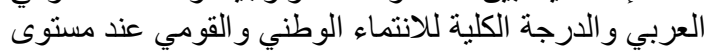

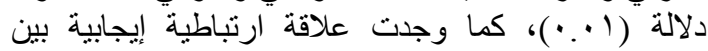
الضغوط التكنولوجية والانتماء الوطني عند مستوى دلالة النة

$$
\text { . ( . . (. }
$$

ع- بالنسبة للارجة الكلية للضغوط الييئية، كان هناك ارتباط ذو دلالة إحصائية بين الارجة الكائية الكلية للضغنوط

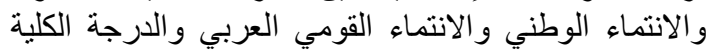

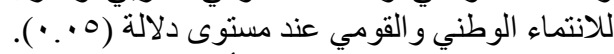

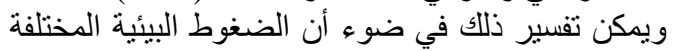

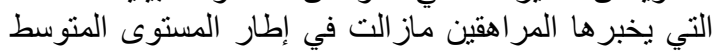

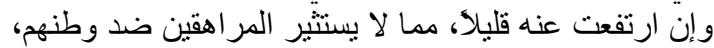

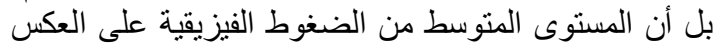

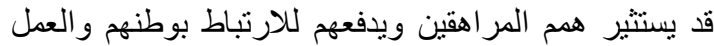

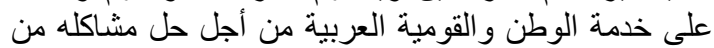

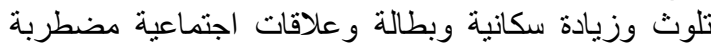
وغيرها من المشكلات البيئية، وهذا قداتية يفسر معاملات 


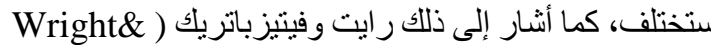

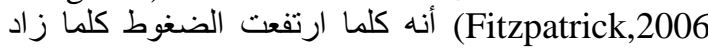

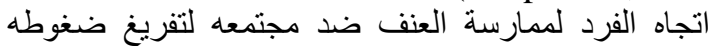

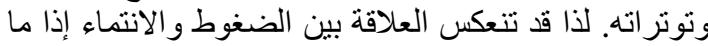

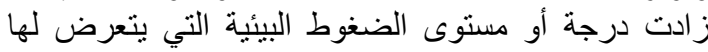

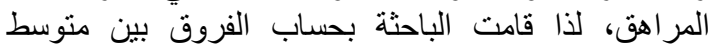

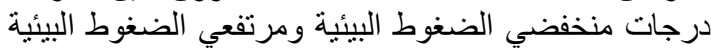
في كل من الانتماء الوطني و القومي و الدرجة الكلية للانتماء، التئية

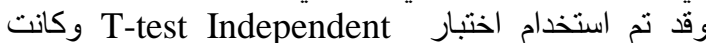
النتائج كما هو موضح بالجدال بالجدال النالي:

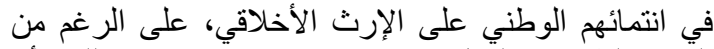

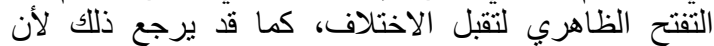

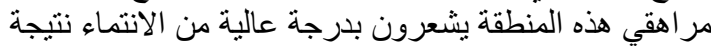

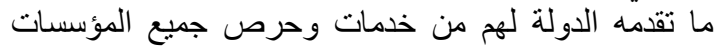

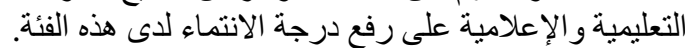

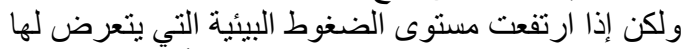

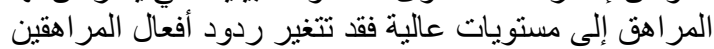

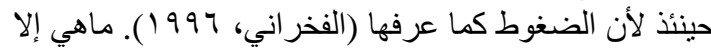

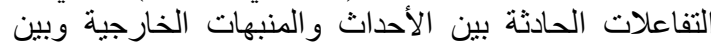

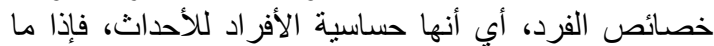
زادت درجة الأحداث أو الضغوط فإن ردود أفعال الأفراد الثاد

\begin{tabular}{|c|c|c|c|c|c|c|}
\hline \multirow[t]{2}{*}{ " " ودلالتها } & \multicolumn{2}{|c|}{ منخفضي الضغوط البيئية } & \multicolumn{2}{|c|}{ مرتفعي الضغوط البيئية } & & \\
\hline & الانحراف المعياري & & الانحراف المعياري & & & \\
\hline$* 0, r \leqslant 0$ & Tr.qV & $1 T 4 . \leqslant Y$ & rT.AT & 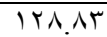 & & \\
\hline$* \varepsilon . \leqslant 99$ & Tr.s. & $1 T r . \leqslant Y$ & TY.YI & IYY.TT & & \\
\hline$* * 1$. . $\vee 9$ & $\leqslant Y .1 \leqslant$ & r79.10 & $\sum 0.7 T$ & rol.0. & الارجة الكلية للانتماء & \\
\hline
\end{tabular}

( ) لقيم "ت" لدلالة الفروق بين منوسطات درجات مرتفعي ومنخفضي الضغوط البيئية في الانتماء الوطني و القومي.

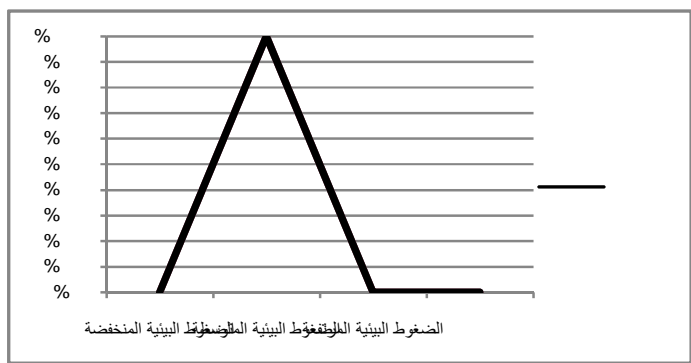

( ) والوفي العلاقة بين مستوى الضغوط البيئية ودرجة الانتماء الوطني و القومي العربي لدى المر الهقين.

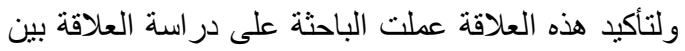

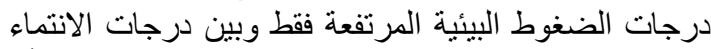

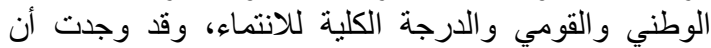

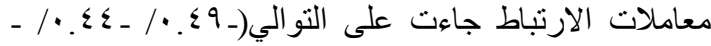

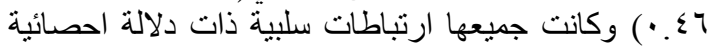

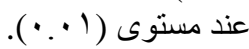

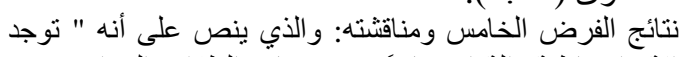

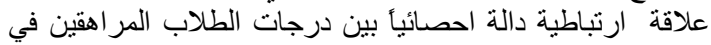

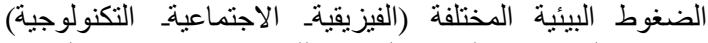

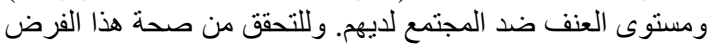

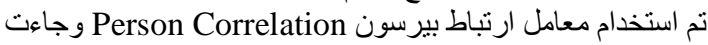
النتائج كما يوضحها معامل الجدول رقم (1)
وقد تبين من الجدول السابق رقم ( • (1) أن هنالك فروق

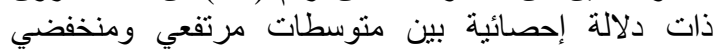

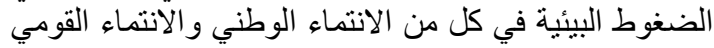

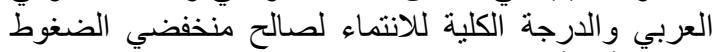

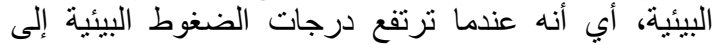

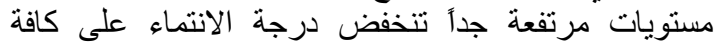

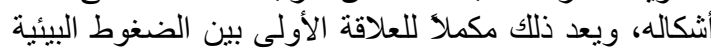

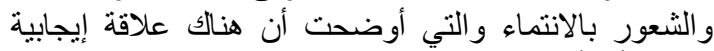

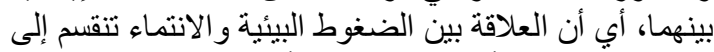

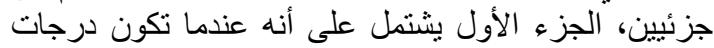

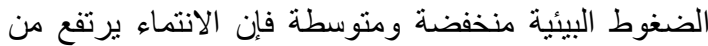
أجل حماية الوطن وقيمه، ولكن في الجزء الجن الثاني من العلاقة

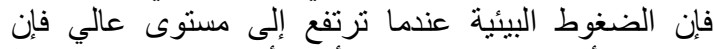

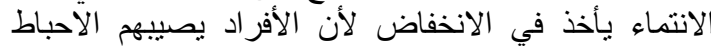

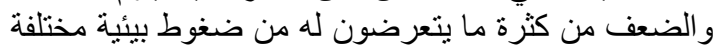

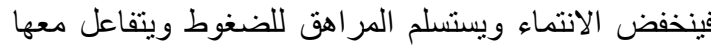

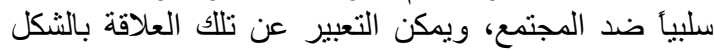
التالي: - n

\begin{tabular}{|c|c|c|c|}
\hline \multirow[b]{2}{*}{ الارجة الكلية للعنف } & & & \multirow[t]{2}{*}{ الضغوط البيئية } \\
\hline & & & \\
\hline$* * .0 \leqslant 1$ & $* * . \leq 99$ & $* * . \leqslant 7 \wedge$ & الضغوط الفيزيقية \\
\hline$* * .0 Y \leqslant$ & *. M & $* * .0 \vee 9$ & الضغوط الاجتماعية \\
\hline$* . Y V T$ & $* . \Gamma \wedge 0$ & $\because 1 \cdot r$ & الضغوط التكنولوجية \\
\hline$* * .00 \leqslant$ & **. Or & $* * . \leq 0 \wedge$ & اللارجة الكلية للضغوط البيئية \\
\hline
\end{tabular}




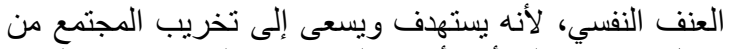

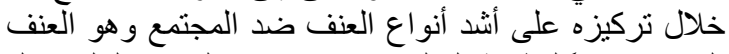

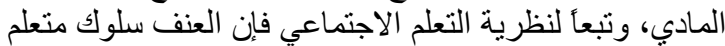

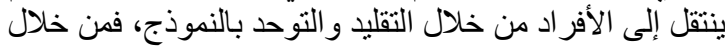

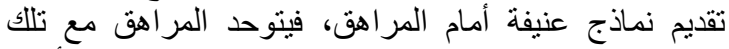

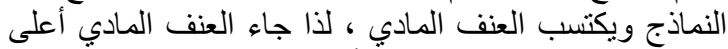

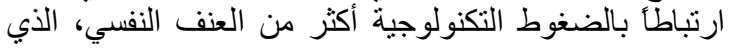

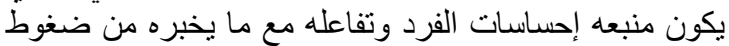

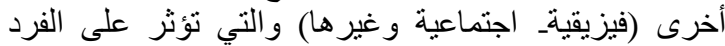

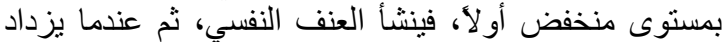

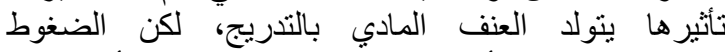

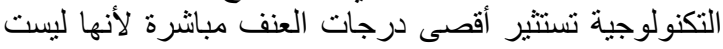

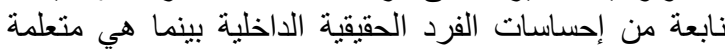

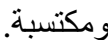

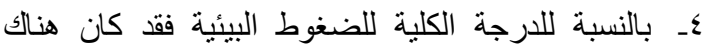

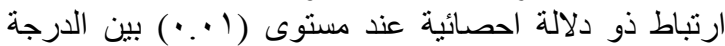

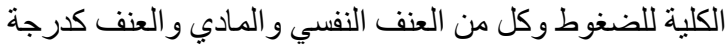

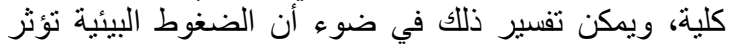

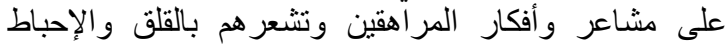

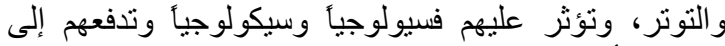

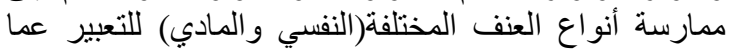
يخبرونه من ضغوط بئئية مختلفة. ويتفق ذلك مع دراسة رايت وفيتزباتريك ( Wright,\& (Fitzpatrick, 2006

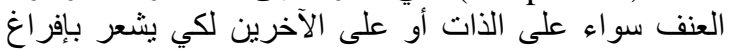

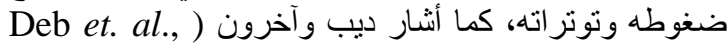

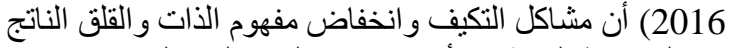

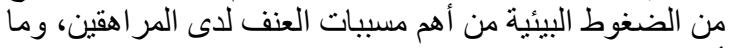

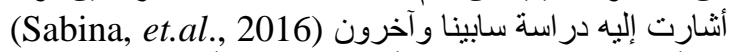

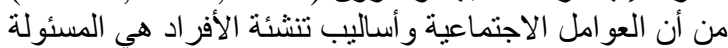

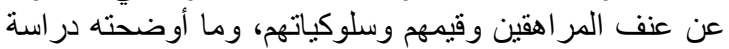

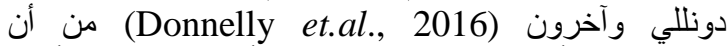
المراهقين يتأثرون بثلاث مركبات أساسية هي الأسرة

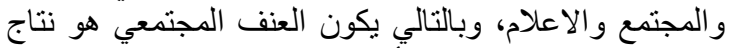

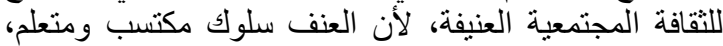

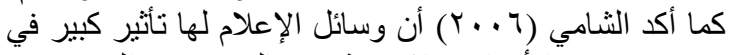

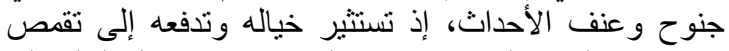

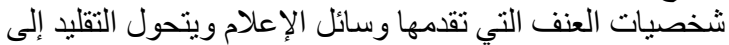

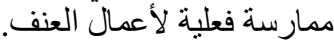

ادس ومناقشته: والذي ينص على أنه " الذهان

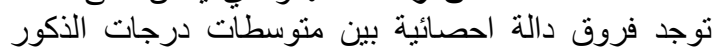

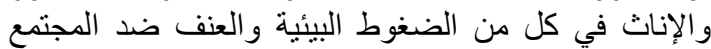

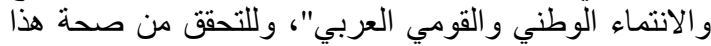

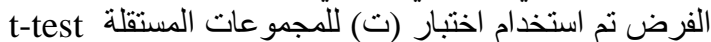
Independent Sample ، وجاءت النتائج كما يوضحها

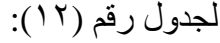

$$
\text { يتضح من الجدول السابق رقم (11 ) ما يلي: }
$$

ا - بالنسبة للضغوط الفيزيقية كان هنالك ارتباط إيجابي ذو دون

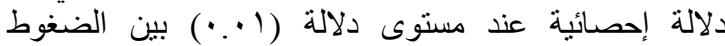

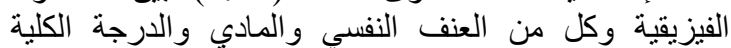

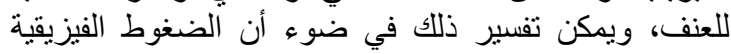

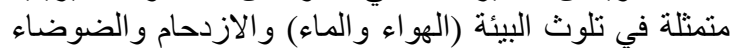

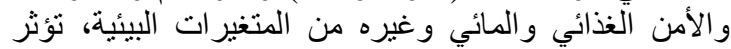

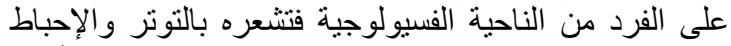

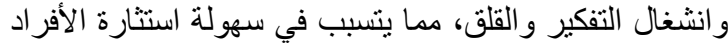
لأبسط الأسباب، وتجعله يعبر عن هذه الاستثارة بأثكال العنف

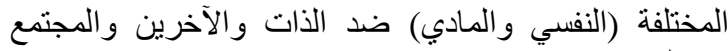
وممتلكاته.

r بالنسبة للضغوط الاجتماعية كان هناك ارتباط ذو دلالة

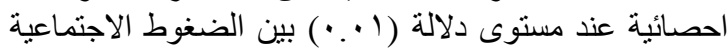

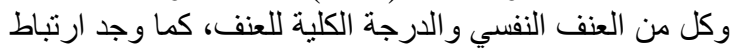

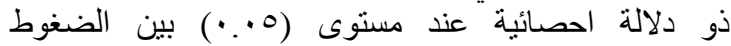

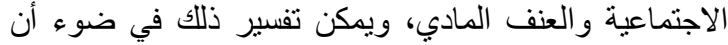

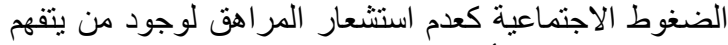

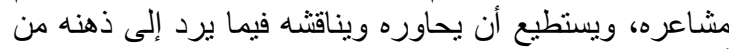

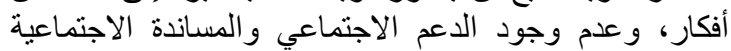

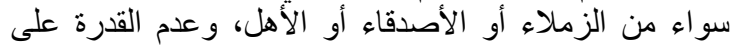

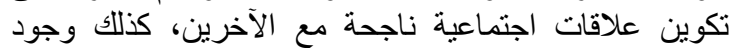

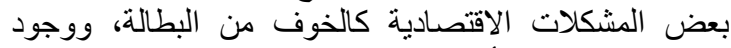

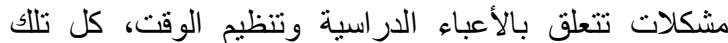

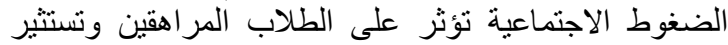

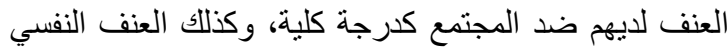

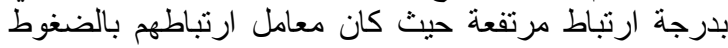

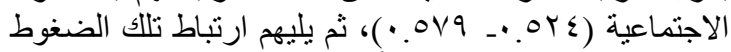

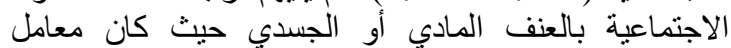

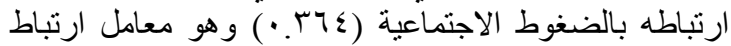

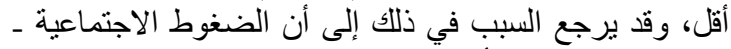

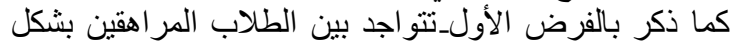

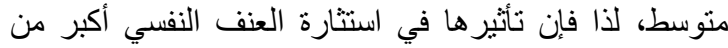

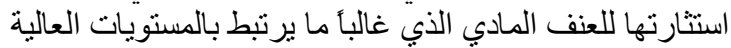

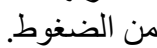

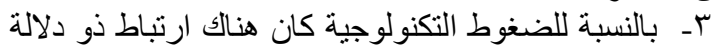

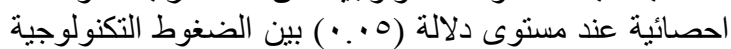

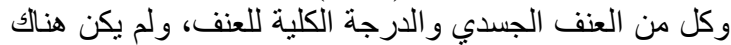

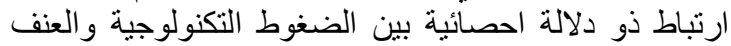

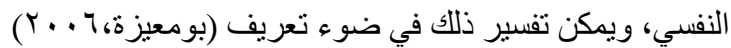
للضغوط التكنولوجية بأنها تعني تأثير وسائل التقنية التهية الحديثة

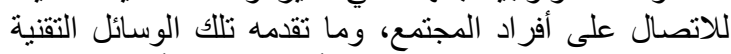

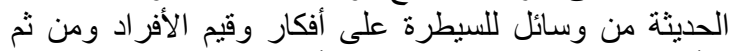

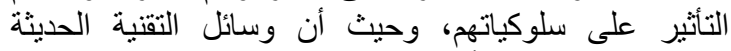

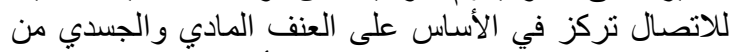

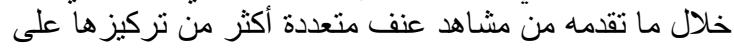




\begin{tabular}{|c|c|c|c|c|c|}
\hline \multirow[t]{2}{*}{ " " ودلالتها } & \multicolumn{2}{|l|}{$(=)$} & \multicolumn{2}{|l|}{$(=)$} & \\
\hline & الانحراف المعياري & & الانحر اف المعياري & & \\
\hline$*$. & - & . & • & • & الضغوط الفيزيقية \\
\hline$*$. & . & . & - & $\bullet$ & الضغوط الاجتماعية \\
\hline$*$. & - & . & • & • & الضغوط التكنولوجية \\
\hline$*$. & - & . & . & . & اللارجة الكلية للضغوط البيئية \\
\hline$*$. & • & . & • & • & \\
\hline . & . & . & . & . & \\
\hline$*$. & • & . & . & • & الدرجة الكلية للعنف \\
\hline . & . & . & - & . & \\
\hline • & • & . & . & • & \\
\hline . & • & . & • & • & الارجة الكلية للانتماء \\
\hline
\end{tabular}

( لقيم "ت" لالالة الفروق بين منوسطات درجات الذكور و الإناث في متغير ات الدر اسة.

التنشئة الاجتماعية الإسلامية بالمجتمع والتي تنبذ العدوان العان الإني

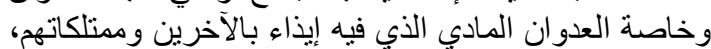

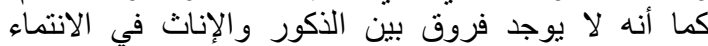

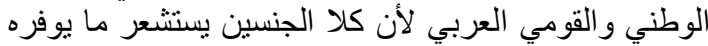

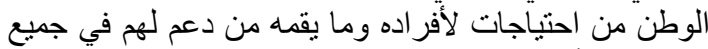

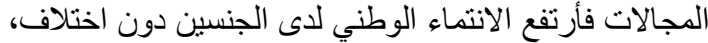

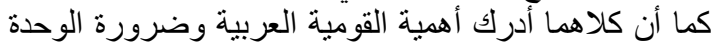

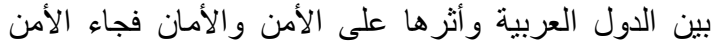
القومي العربي مرتفع دون اختلاف بين الجن الجنسين.

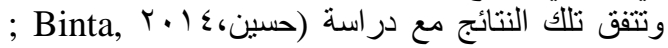
et.al., 2015 ; Slone, \& Mayer, 2015 ; Calvete, في أن الذكور أكثر عنفاً من الإناث، وتختلف (et.al., 2015

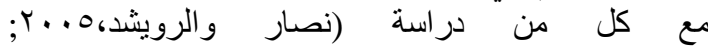

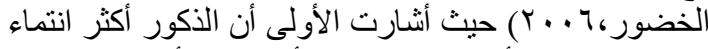

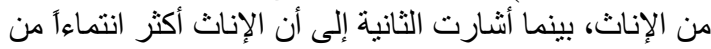

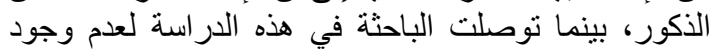

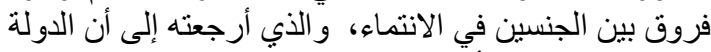

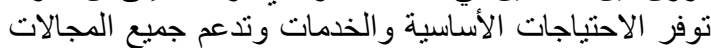

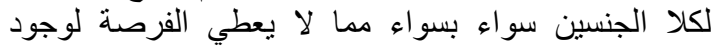

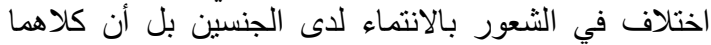

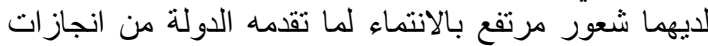

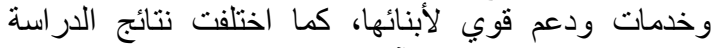
الحالية مع دراسة كيم وآخرون (Kim, et.al., 2016)

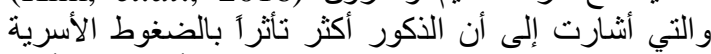

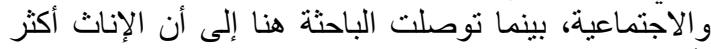

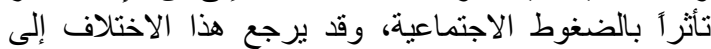

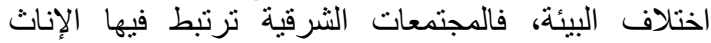

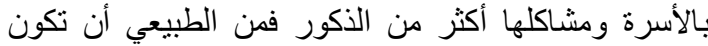

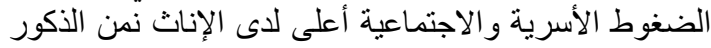

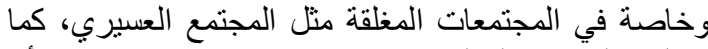

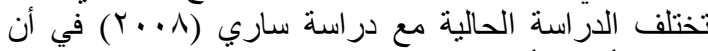

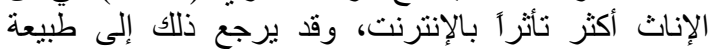

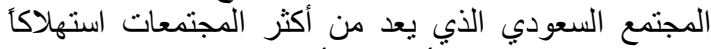

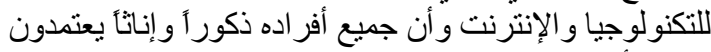

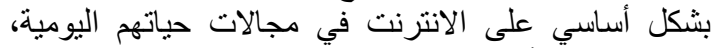

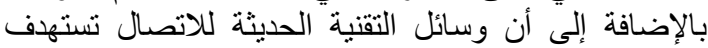

لتضح من الجدول السابق رقم (YI) وجود فروق ذات

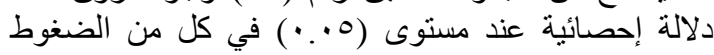

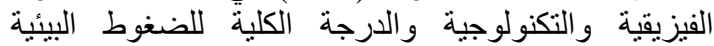

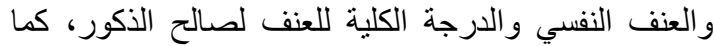

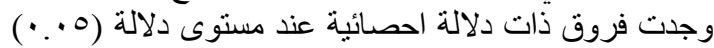

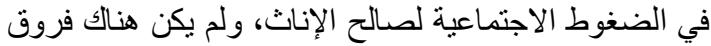
ذات دلالة إحصائية بين الذكور والإناثية في كل من العنف الإنف

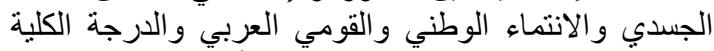

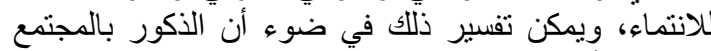

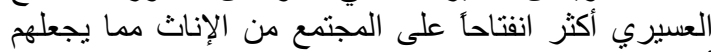

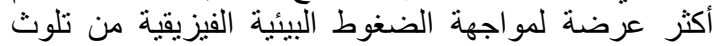

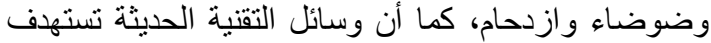
الذكور أكثر من استهدافها للإناث لمحاولة ألة فرضئل فرض السيطرة

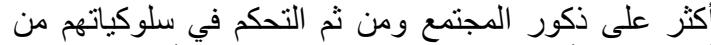

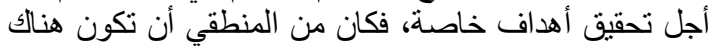

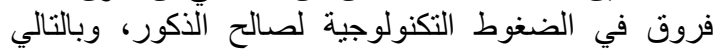

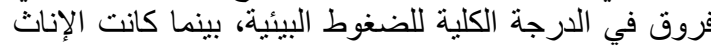

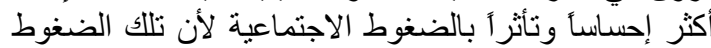

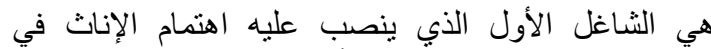
المنطقة، حيث يتمركز تفكير ها أكثر في علاقاتها الاجتماعية الإنية

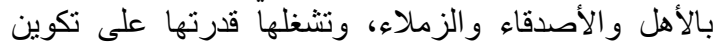

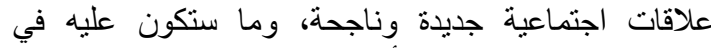

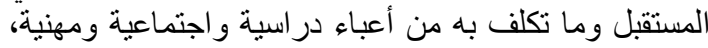

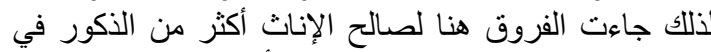

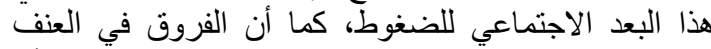

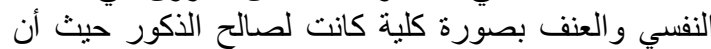

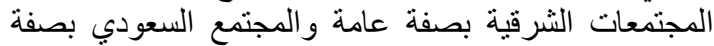

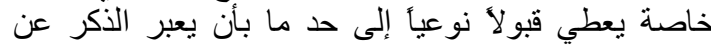

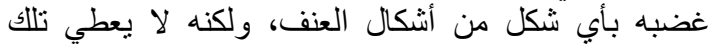

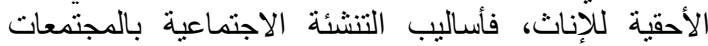
الثرقية تكون حريصة على إظهار الأنثى بصورة هادئة الأنة

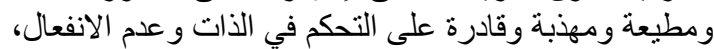

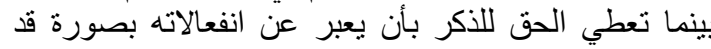

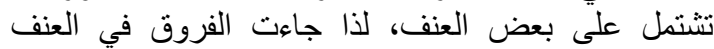

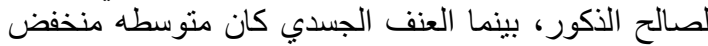

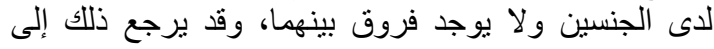




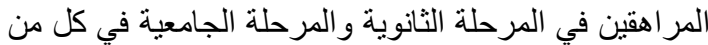

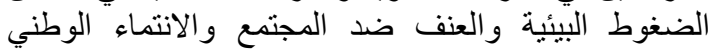
و القومي العربي"، وللتحقق من صحة هذا الفرض تم النف التخدام

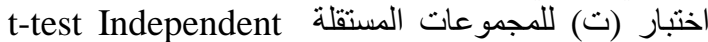
Sample

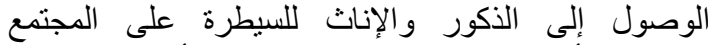

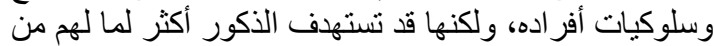

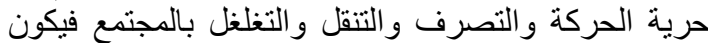
تأثير هم في المجتمع أكبر و أكثر حساسية.

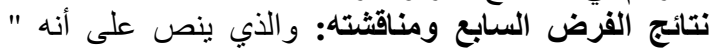
توجد فروق دالة احصائياً بين متوسطات درجات النئن الطلاب

\begin{tabular}{|c|c|c|c|c|c|}
\hline \multirow[t]{2}{*}{ " " " ودلالتها } & \multicolumn{2}{|c|}{ المرحلة الثانوية ( = } & \multicolumn{2}{|c|}{ المرحلة الجامعية ( = ) } & \\
\hline & الانحراف المعياري & & الانحراف المعياري & & \\
\hline$*$. & . & . & • & . & الضغوط الفيزيقية \\
\hline$*$. & • & . & • & • & الضغوط الاجتماعية \\
\hline$* * \quad$. & . & . & . & . & الضغوط التكنولوجية \\
\hline$*$. & • & . & • & . & الكلية للضغوط البيئية \\
\hline$*$ & • & . & . & • & \\
\hline • & . & . & . & . & \\
\hline$*$. & . & . & . & . & الارجة الكلية للعنف \\
\hline$*$. & • & . & . & . & \\
\hline$*$. & . & . & . & . & \\
\hline$*$. & • & . & . & . & الارجة الكلية للانتماء \\
\hline
\end{tabular}

( ) لقيم "ت" لدلالة الفروق بين متوسطات درجات الذكور والإناث في متغير ات الدراسة.

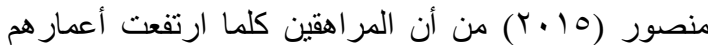

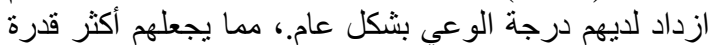

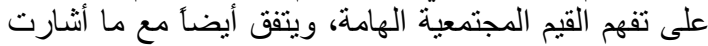

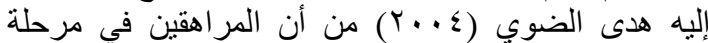

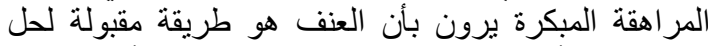
المشكلات وأنه الطريقة الطبيعية للتعامل مع الأشياء ولئه وحل

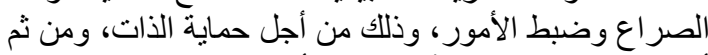

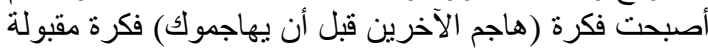

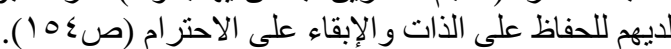

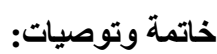
يتضح من الدراسة الحالية مفهوم الضغوط البيئية وتأثيرها على الحالة النفسية للفرد، فالضغط البئئي يحدث البئ من خلال تفاعل المتغير ات البيئية مع المتغيرات الذاتئية للتئية للفرد، كما تبين العلاقة الإيجابية بين الضغوط البئية البيئية المختلفة وبين نموني

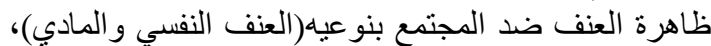

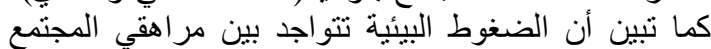

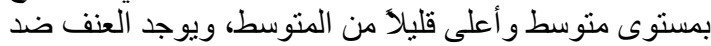

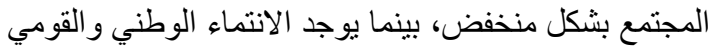

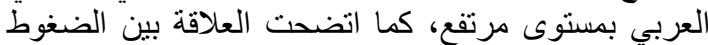

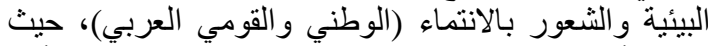

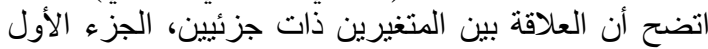

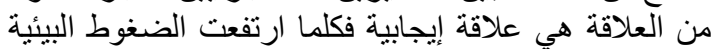

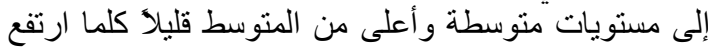

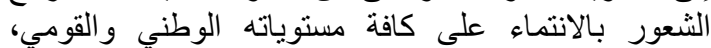

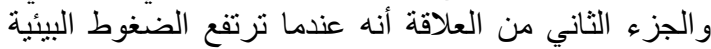

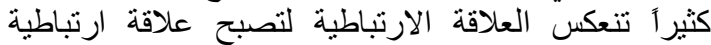

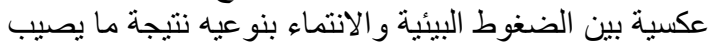
الفرد من احباط، ثم كثفت الدراسة عن الفروق بين الذكور
يتضح من الجدول رقم (rا1) لسابق وجود فروق ذات

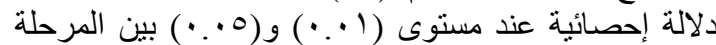

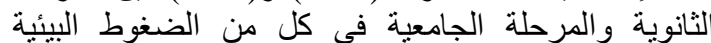

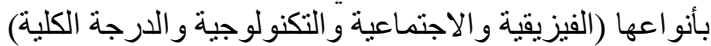

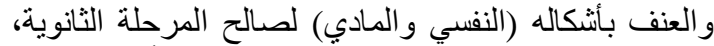
حيث كان الطلاب المرأهقين بالمرحلة الثانوية أكثر إحساسأ

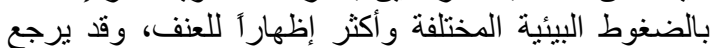
ذللك بسبب أن المر اهقين في المرحلة الثانوية يكونية لإنون منأثرين

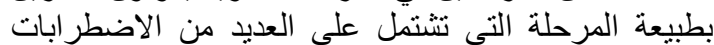

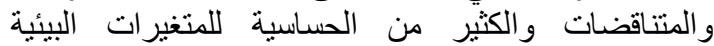

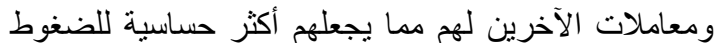

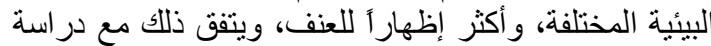

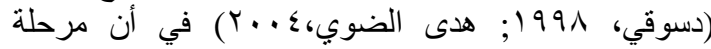

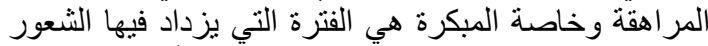

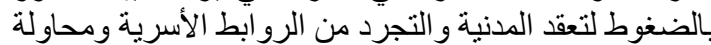

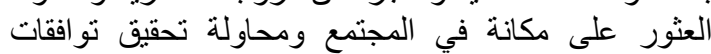
جنسية، مما يجعل المر أهق أكثر حساسية وأكثر على عدوان.

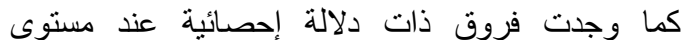
(0.0. · ) بين المرحلة الثانوية والمرحلة الجامعية في الانتماء

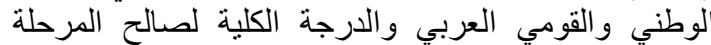

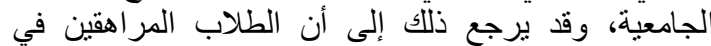

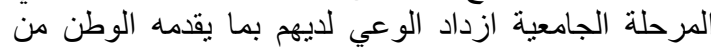

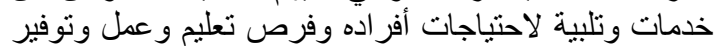

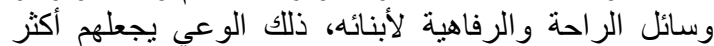

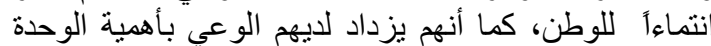

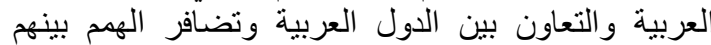

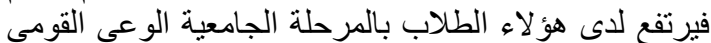
العربي والانتماء كدرجة كلية، ويتفق ذللك ما أثنار إلية 
:

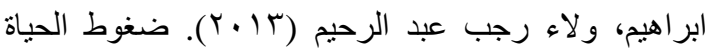

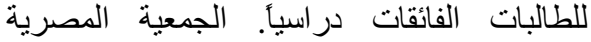

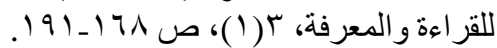

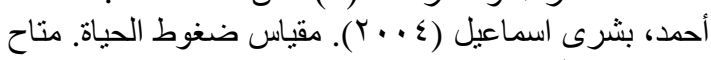

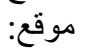
على http://uqu.edu.sa/page/ar/88637

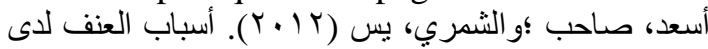

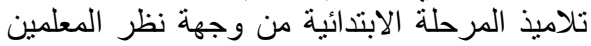

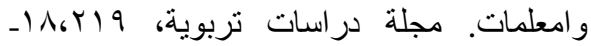
ro.

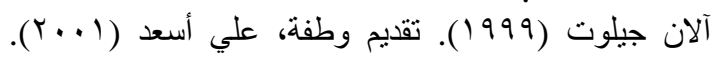

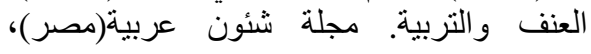

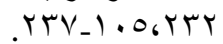

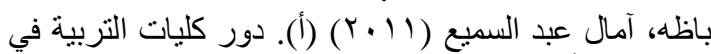
تأصيل الهوية لدى الثباب، المؤتمر العلمي الثامن،

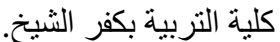

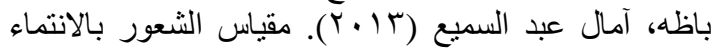

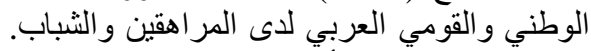

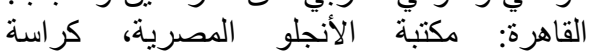

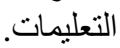

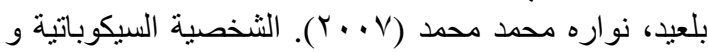

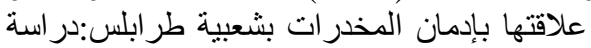
عن نز لاء مركز رعاية و تأهيل مدمني المخدرات

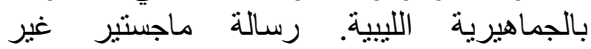
منشورة،كلية الآداب، جامعة أم درمان الإسلامية، ليييا.

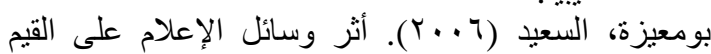

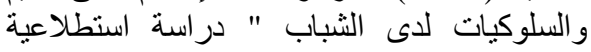
بمنطقة البليد. رسالة دكتوراه غير لإب منشورة، كلية

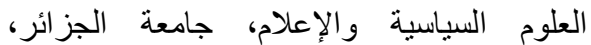

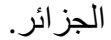

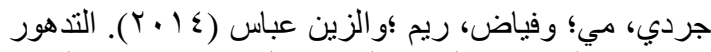
البيئي في الوطن العربي: التحدي لاسيندامة العين الحياة.

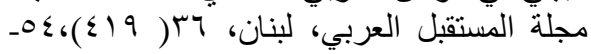
. $v \varepsilon$

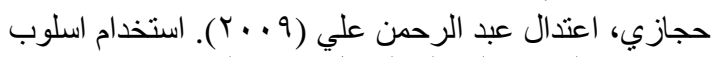

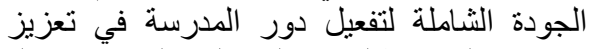

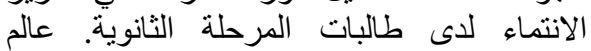
التربية، رابطة التربية التربية الحديثة، القاهرة،

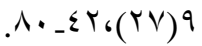

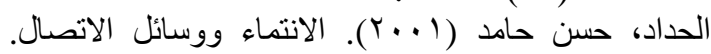

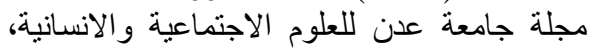

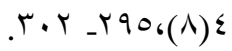

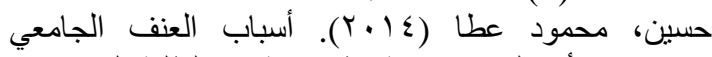
و أنثكاله من وجهة نظر عينة من الطلبة الجامعيين. مجلة جامعة الأقصى (سلسلة العلوم الإنسانية)، . 197 - 171 (1) (1)

حطب، زهير (1991). العولمة والعنف. مجلة الفكر (1919)

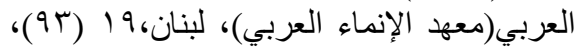

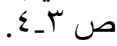

والإناث في متغيرات الدراسة ليتضح أن الذكور أكثر تأثرا

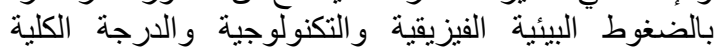

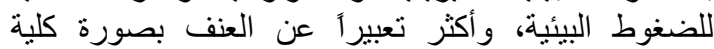

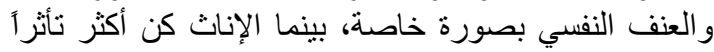

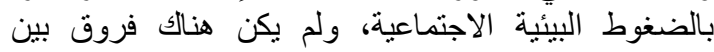

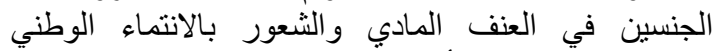

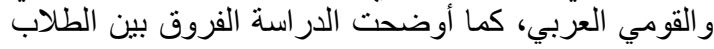

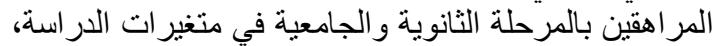

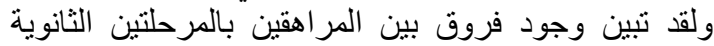

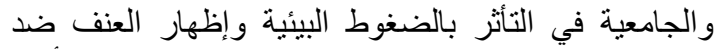

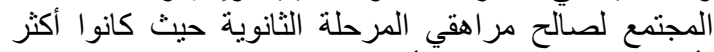

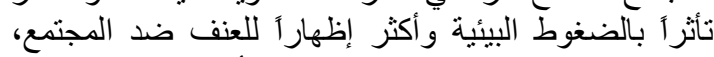
بينما كان مراهقي المرحلة الجامعية أكثر انتماءاء للوطن لفئن

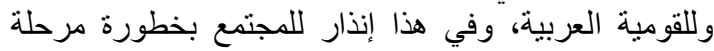

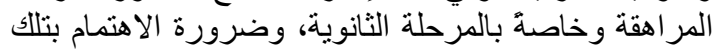

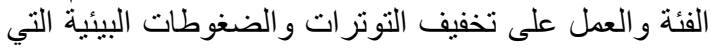

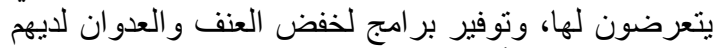

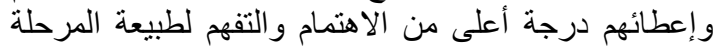

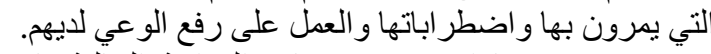
وفي ضوء ما اسفرت عنده نتائج الدراسة الحالّية فإنه التها يمكن تقديم مجمو عة من التوصيات التالية:

- بضرورة الاهتمام بالخدمات المجتمعية لحل مشاكل البيئة

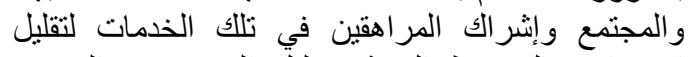
الاحساس بالضغوط والثناك البيئية وتقليل العنف ضد المجتمع وتقوية الانتماء الوطني.

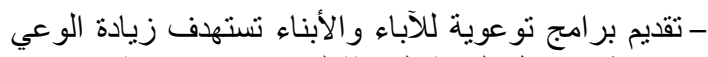
بمخاطر وسائل التقنية الحديثة للاتصالات وكئاء وكيفية الاستفادة من شقها الإيجابي و الحذر من شقها السلبي ومخاطر ها التئي التئي

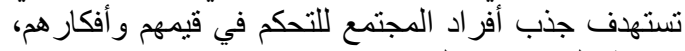
ومن ثم التحكم في سلوكياتهم.

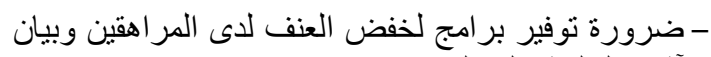
آثاره السلبية على المجتمع.

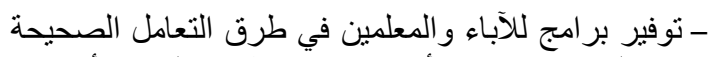
مع المراهقين من الأبناء وكيفية إظهار التفهم لأفكارهم

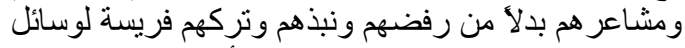

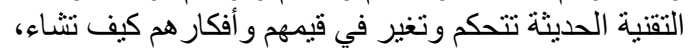

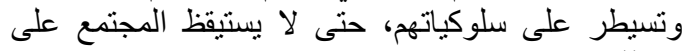
كارثة. - مبنر

- زيادة التركيز على برامج الانتماء الوطني والقومي لإني

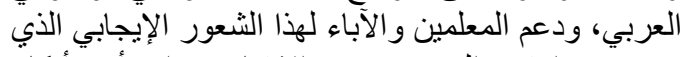
يحمي مراهقي المجتمع من الانقياد وراء أي أفكار الأبراي

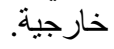

- التركيز على مر اهقي المرحلة الثانوية في تقديم الخدمات

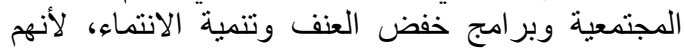
بحكم طبيعة المراهقة المبكرة الأكثر اضطر ابأ، يكونون

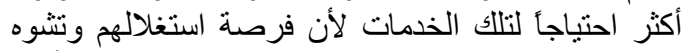

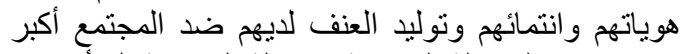
من مر اهقي المرحلة الجامعية (مرحلة المراهقة المتأخرة). 
الأزهر بغزة، سلسلة العلوم الإنسانية، ؟((1)،

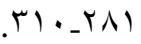

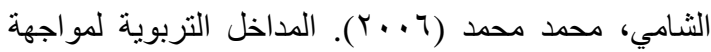

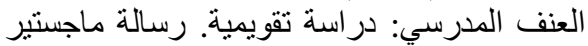

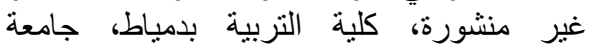

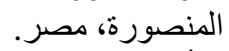

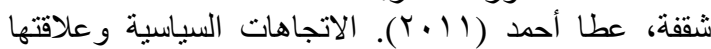

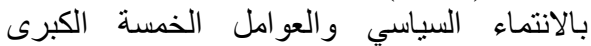

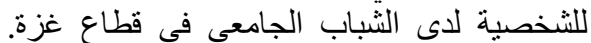

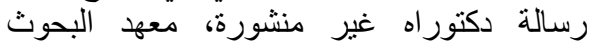
و والدر اسات العربية، جامعة الدول العربية.

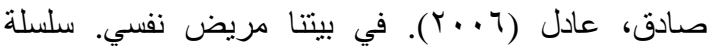

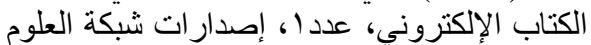

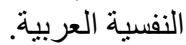

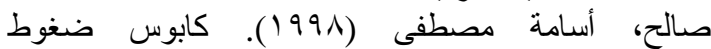

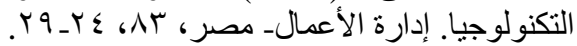

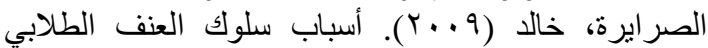

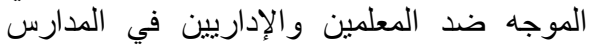

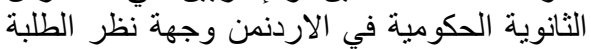

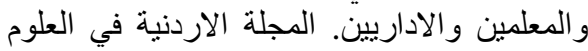

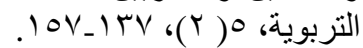

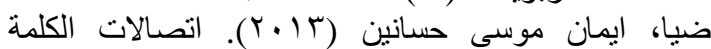
الالكترونية عبر موروانع الثبكات الثبات الاجتماعية ودورها في المشاركة السياسية للثباب "دراسية النية

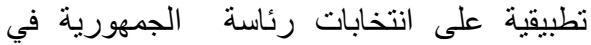
مصر". رسالة ماجستير غير منئة منشورة، كلية فئة التجارة، جامعة المنصورة.

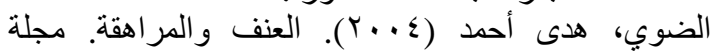

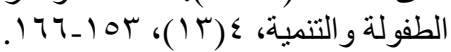

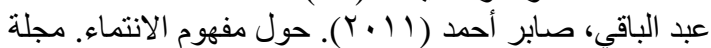

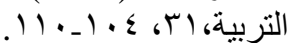

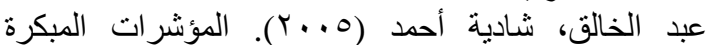

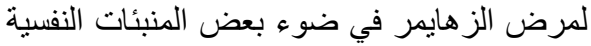

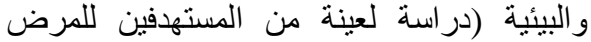

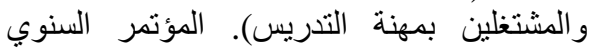
العاثر إدارة الأزمات والكوارث البنات البيئية في ظلت كلئ المتغيرات و المستجدات العالمئية المعاصرة المرة، كلية

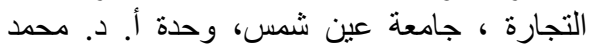

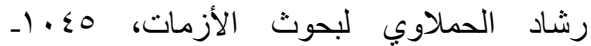
. 1.71

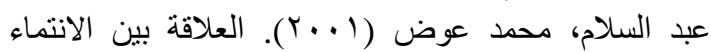

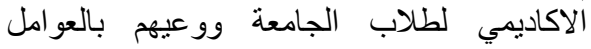
المؤدية إلى مشكلات البيئة "دراسة ميدانية في لبانية

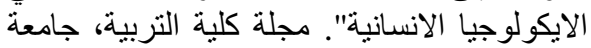

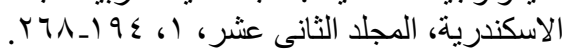

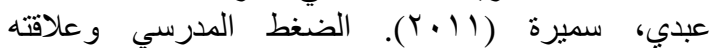
بسلوكيات العنف و التحصيل الدر اسي لدى الدي المر اهق

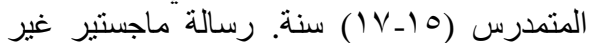

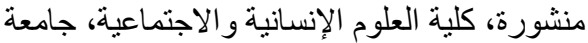

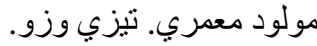

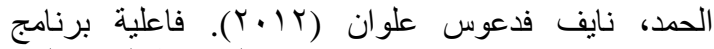

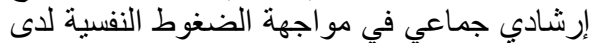

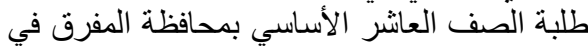

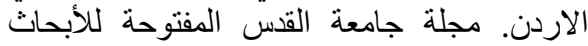

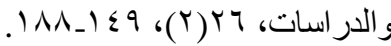

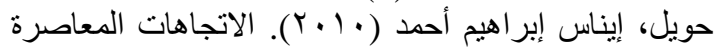

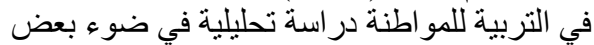

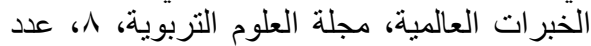

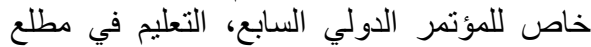

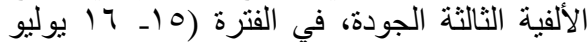

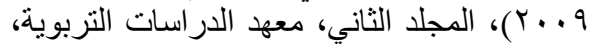

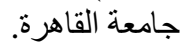

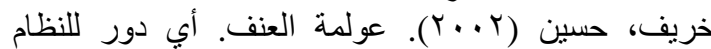

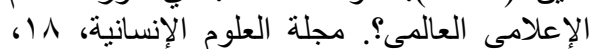

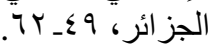

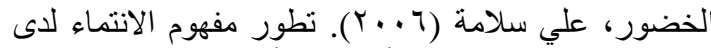

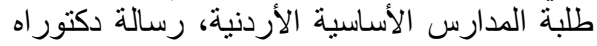

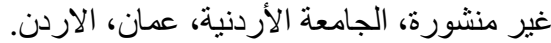

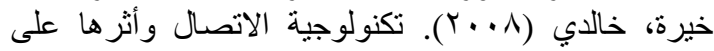

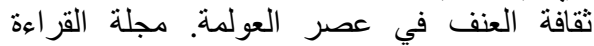

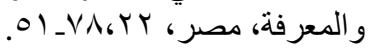
دسوقي، كمال (1991) ذخيرة علوم النفس. المجلد الأول،

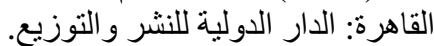

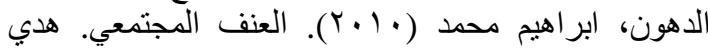

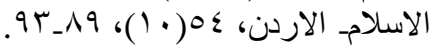

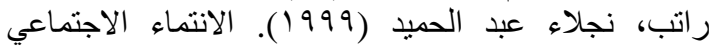
اللثباب المصري "در اسة سوسيولوجية في حقيبة الأنية

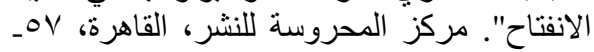
.9V

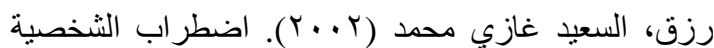
السيكوباتية لدى المر اهقين و الراشدين بمؤسيسات

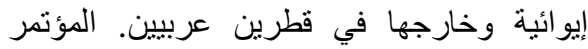
السنوي التاسع(الارشاد النفسي قوة للتمية و التقدم)،

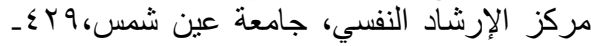
( )

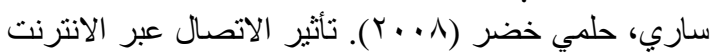

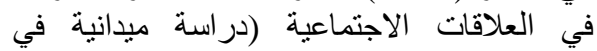

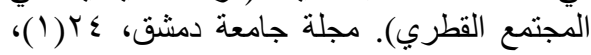
rol -r90

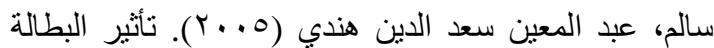

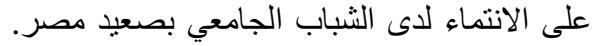

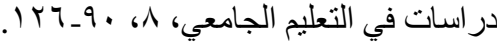

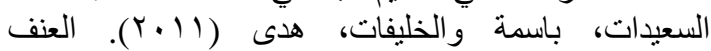

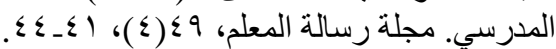

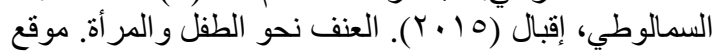

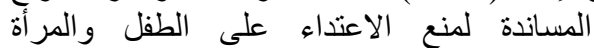
www.musanadah.com

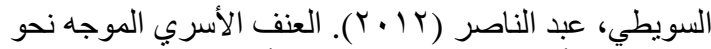

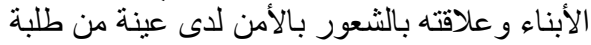
الصف التاسع في مدينة الخليل. مجلة جامعة لألة 


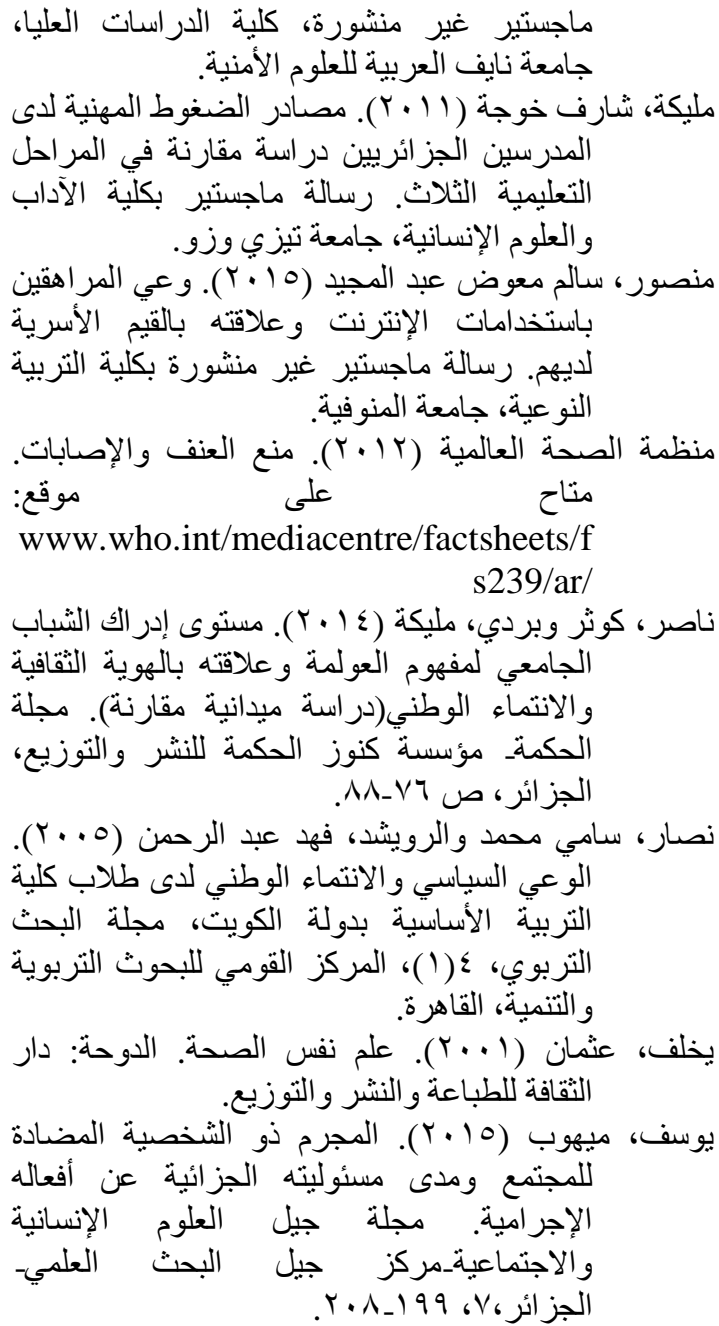

Alan, C. \& Robert, J. (1998). Management Process and Organization Behavior. Scott Foreman \& Company, pp 357359.

Baker, B. (1998). What is Voice? Issues of Identity, Review of Educational Research, Vol. 69(4), p 365- 384.

Binta, A., Claudette, G., Trenette, C. \& Qiana, C. (2015). The role of fathers in reducing dating violence victimization and sexual risk behaviors among a national sample of Black adolescents. Children and Youth Services Review, Vol.55, p 48-55.

Calvete, E., Orue, I. \& Manuel, G. (2015). Reciprocal longitudinal associations between substance use and child-toparent violence in adolescents. Journal of Adolescence, Vol. 44, p 124-133.

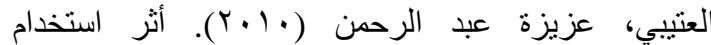

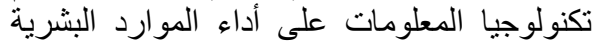
"در اسة ميدانية على الأكاديمية الدولية الاستر الية.

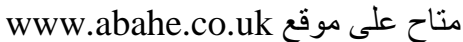

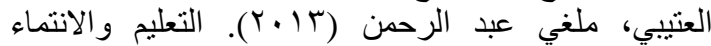

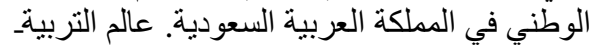

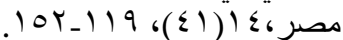

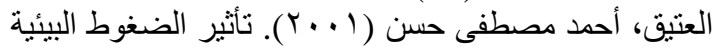

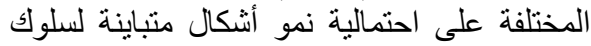

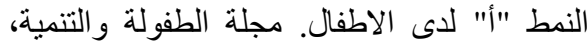

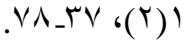

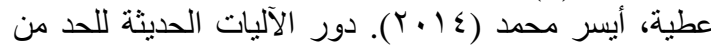

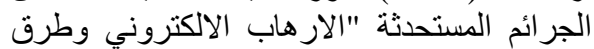

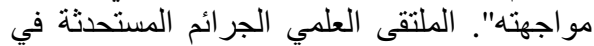
ظل المتغيرات و التحولات الإقليمية والدولية الدولية، كلية

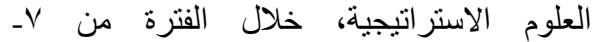
r/ 1/9

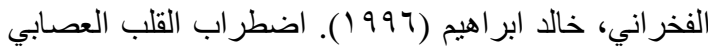

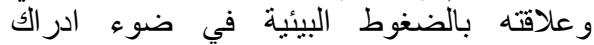
الأعراض في الآخرين. المؤتمر الدولئه الأولي الأول

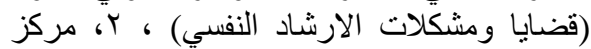

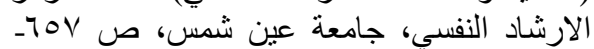
.711

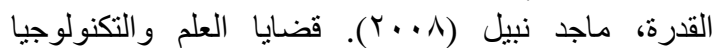

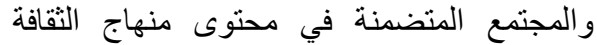

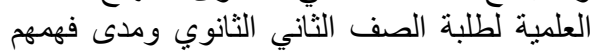

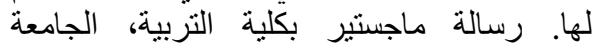
الإسلامية، غزة الإنة

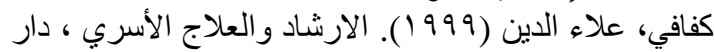

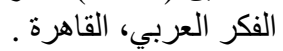

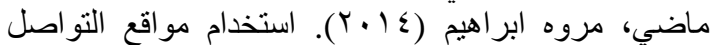

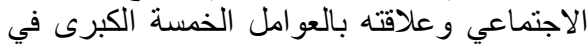

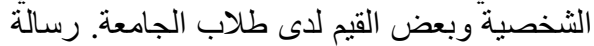

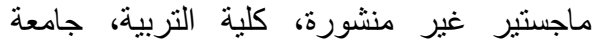
المنصورة.

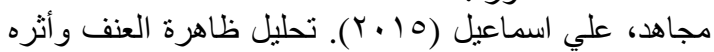

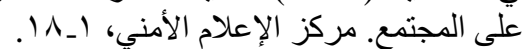

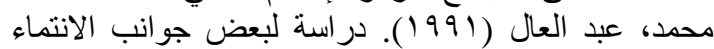

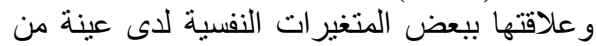

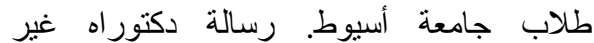

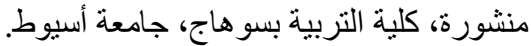

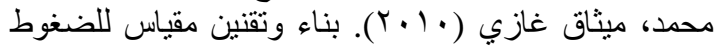

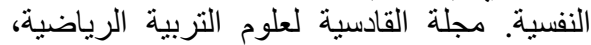

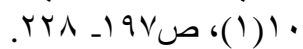

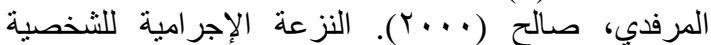
السيكوباتية. مجلة العلوم الاجتماعية والإنسة الانسانية، r

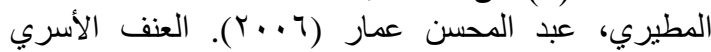

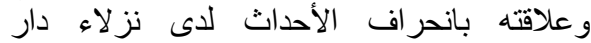
الملاحظة الاجتماعية بمدينة الرياض. لإن رسالة لاء 
Ling, X., Cody, D. \& Steven, D. (2013). Selfsupporting personality and psychological symptoms: The mediating effects of stress and social support. Personality and Individual Differences, Vol. 54(3), p408-413.

Park, N., Song, H. \& Min Lee, K. (2014). Social networking sites and other media use, acculturation stress, and psychological well-being among East Asian college students in the United States. Computers in Human Behavior, Vol. 36, p138-146.

Sabina, C., Cuevas, C. \& Heather, M. (2016). Longitudinal dating violence victimization among Latino teens: Rates, risk factors, and cultural influences. Journal of Adolescence, Vol. 47, p 5-15.

Slone, M. \& Mayer, Y. (2015). Gender differences in mental health consequences of exposure to political violence among Israeli adolescents. Children and Youth Services Review, Vol. 58, p 170-178.

Soylu, A. \& Campbell, S. (2012). Physical and emotional stresses of technology on employees in the workplace.Journal of Employment Counseling, Vol. 49 (3), p130-139.

Sukharev, V. \& Zschech, E. (2011). MultiScale Environment For Simulation And Materials Characterization In Stress Management For 3D IC TSVBased Technologies - Effect Of Stress On The Device Characteristics. AIP Conference Proceedings, Vol. 1378 (1), p21-48.

Tahereh, A., Shirin, H., Naemeh, S., Farid, Z., Tracy, L. \& Yadollah, P. (2015). Psychometric testing of the Persian version of the Belongingness Scale Clinical Placement Experience. Nurse Education Today, Vol. 35(3), P. 439443.

Tiwari, T. Anju, L. \& Indramani, L. (2008). Information Technology-Induced Stress and Human Performance: A Critical Review. Journal of the Indian Academy of Applied Psychology, Vol. 34(2), p 241-249.
Deb, S., Ray. M., Bhattacharyya, B. \& Sun, J. (2016). Violence against the adolescents of Kolkata: A study in relation to the socio-economic background and mental health. Asian Journal of Psychiatry, Vol. 19, p 4-13.

Donnelly, E., Oehme, K. \& Melvin, R. (2016). What do EMS personnel think about domestic violence? An exploration of attitudes and experiences after participation in training. Journal of Forensic and Legal Medicine, Vol. 38, p64-69.

Idriss, C. (2003). Citizenship, Schooling and Bational Identity in Contemporary Germany. PhD, University of Michigan.

Gemmill, E. \& Peterson, M. (2006). Technology Use Among College Students: Implications for Student Affairs Professionals. NASPA Journal, Vol. 43 (2), p, 280- 300.

Glass, G. \& Westmont, G. (2014). Comparative effects of belongingness on the academic success and crosscultural interactions of domestic and international students. International Journal of Comparative effects, Vol. 38, P. 106-119.

Kashimoto, R., Toffoli, L., Manfredo, V., Martins-Pinge, M. \& Pelosi, G. (2016). Physical exercise affects the epigenetic programming of rat brain and modulates the adaptive response evoked by repeated restraint stress. Behavioral Brain Research. Vol.296. p 286-289.

Kim, E., Inga, D., Jon, F. \& Gisli, H. (2016). Investigating the interplay between the reported witnessing and experiencing of physical violence within the home, the death of a parent or sibling, stresssensitivity, and reported false confessions in males. Personality and Individual Differencesm Vol. 88(1). P 114-119.

Lazarus, R. \& Folkman, S. (1987). Transactional theory and research on emotions and coping. European Journal of Personality, Vol. 1(3), p141-169. 
Psychiatry Research, Vol. 230 (2), Rosenbaum, S., Davy, V., Steel, Z., Jill, N., p130-136. Philip, B. \& Brendon, S. (2015).

Wright, J. \& Fitzpatrick, K. (2006). Social Physical activity in the treatment of Capital and Adolescent Violent Post-traumatic stress disorder: A Behavior. Social Forces, Vol. 84 (3), p systematic review and meta-analysis.

\title{
The Impact of Different Ecological Pressures on Belongingness and the Possibility of Violence Growth Against Society for Teenagers
}

\author{
Sally salah anter kassem \\ Mental Health Department, Faculty of education, Suez canal university.
}

\begin{abstract}
The current study aimed at determining the level of ecological Stress (physical, social and technological ones), violence against society and belongingness for teenagers and determining the relation between ecological Stress and both belongingness and violence. It also aimed at studying the differences between the study variables that are related to sex and educational level. The study was applied on a sample of 200 teenage students $(\mathrm{N}=200)$ in secondary schools and university levels. The descriptive correlative method was used to determine the level of the study variables, examine the relation between the ecological pressures and both violence and belongingness and find the differences in study variables that are related to sex and educational level. The study found out that ecological Stress (physical, social and technological) are found in a moderate degree for teenagers, belongingness is found in a high degree whereas violence against society is found in a low degree. A statistically significant positive relation was found between low and moderate ecological Stress and belongingness and a negative correlative relation between high ecological Stress and belongingness. statistically significant differences were found between males and females in social ecological Stress for females. No significant differences were found between males and females in national belongingness and Arab nationwide belongingness. Statistically significant differences were found between secondary and university students in ecological pressures, psychological violence and the total degree of violence against society for the secondary students. Statistically significant relations of feeling of belongingness (both national and Arab nationwide) were found for university students. No statistically significant relations were found between university and secondary levels in physical violence.
\end{abstract}

